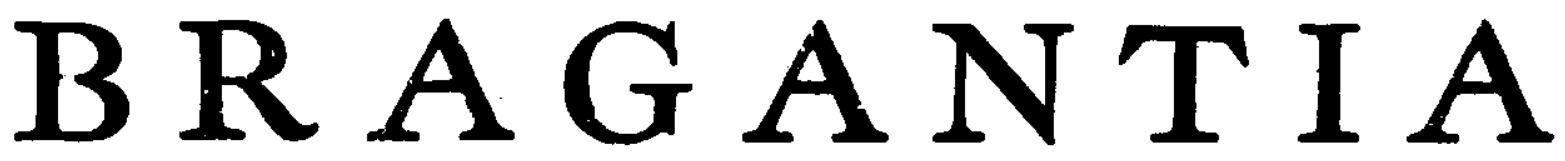

Boletim Técnico da Divisão de Experimentação e Pesquisas INSTITUTO AGRONÔMICO

Vol. 5

Campinas, Agôsto de 1945

N. ${ }^{\circ} 8$

\title{
ESTUDO SÔBRE A COMERCIALIZAÇÃO DE FIGOS E UVAS EM SÃO PAULO(*)
}

Mário D. Homem de Melo

(Comissão de Estudos de Economia Rural da Secretaria da Agricultura)

\section{INTRODUÇ̃̃O}

A cultura comercial da uva, no Estado de São Paulo, é encontrada principalmente em 5 regiões: a) - na zona servida pela Estrada de Ferro Paulista, compreendendo os municípios de Campinas, Itatiba e Jundiaí ; b) - na zona ao longo da Estrada de Ferro Central do Brasil, entre os municípios de São Paulo e Mogi das Cruzes; c) - na região situada ao redor de São Rogue; d) - no município de Salto, na E. F. Sorocabana; e) - nos municípios de Boituva, Tatui e Titêé. As culturas comerciais de figo, no Estado, encontram-se sòmente nas duas primeiras zonas citadas. Estas duas frutas são produzidas não só para consumo "in natura", como também para industrialização: - a uva, como vinho, e o figo, na forma de doces cristalizados e em calda.

A primeira das zonas citadas, é a mais importante de tôdas, pelos seguintes motivos: possui a maior área plantada com essas culturas no Estado $\left(^{\star \star}\right)$, e é a grande produtora dessas frutas para os mercados de São Paulo, Rio de Janeiro e interior do Estado.

Além disso, o estabelecimento das culturas de uva e figo, nessa antiga zona cafeeira, trouxe, como resultado, 0 aparecimento, em grande

(*) A primeira parte dêste trabalho - a da comercialização pelos produtores - com algumas modificações, foi publicada na "Revista do Arquivo Municipal, S. Paulo n. ${ }^{\circ} 96$, pág. 7.53. 1944.

(*) Segundo a Estatística Agrícola e Zootécnica do Estado, para 1939-40, a área plantada com essas culturas na zona representava - $53 \%$ e $42,5 \%$ do total do Estado, para figo e uva, respectivamente. A maior área em culturas de figo encontra-se no distrito de Valinhos, e, a de uva, no distrito de Louveira. 
escala, de um tipo de exploração agrícola pouco comum entre nós, como se pode verificar pelos seguintes caraterísticos da agricultura da zona : pleno desenvolvimento da pequena propriedade rural, com área média de 3 a 5 alqueires; cultivo quase exclusivo de uva e figo em cada propriedade, havendo sòmente pequenas áreas reservadas para outras culturas, tais como feijão, arroz, milho, etc., e, porisso, são explorações de tipo comercial, ao contrário da maioria das pequenas propriedades do Estado que são, em muito maior grau, autosuficientes; pela necessidade de uso intensivo de adubo orgânico nessas culturas, os lavradores são obrigados a produzí-lo no próprio sítio; por exigirem essas frutas um cultivo especial e bem diferente do usado nas culturas. mais comuns no Estado, êstes produtores estão de posse de uma técnica agrícola superior à média dos nossos sitiantes; melhor nível de instrução da população rural devido à maior densidade da população e maior número de sítios localizados à margem das estradas, o que facilita maior afluência às escolas da zona; há um maior contacto entre os. sitiantes, não só devido à proximidade dos sítios entre si, como, também, à necessidade de os produtores irem diàriamente às estações de embarque, na época da safra; finalmente, devido às peculiaridades comerciais dêstes produtos e do tipo de exploração agrícola, os sitiantes estão. em contacto com os negociantes das grandes praças compradoras, 0 que faz com que adquiram melhor conhecimento do comércio de produtos agrícolas.

Todos êstes caraterísticos tornam estas culturas e a própria zona. dignas de estudos interessantes e úteis à economia do Estado. Entretanto, quem percorrer as propriedades produtoras dessas frutas na zona e acompanhar a comercialização do figo e uva, desde que saem das. mãos dos produtores até qr. ₹ cheguem aos consumidores dos grandes. centros como São Paulo, verificará desde logo que o estudo de sua comercialização é o que se mostra de mais imediata necessidade. Isso. porque, não só os lavradores quase não têm meios de defesa contra possíveis explorações por parte dos intermediários, como porque, devido. às falhas e ineficiências do comércio, as frutas não podem chegar até os consumidores por preços mais razoáveis, o que dificulta sua difusão entre as populações urbanas.

Por êsse motivo, resolvemos estudar a comercialização do figo e da uva, a fim de pôr a descoberto suas falhas e sugerir as medidas necessárias para saná-las.

Sanadas as falhas da comercialização, os produtores poderão obter maior lucro, porque aumentarão seu poder de barganha frente aos inter- 
mediários e também porque se porão a coberto de grandes flutuações de preços, não só desde já, mas, principalmente, no futuro, quando aparecer o perigo de uma super-prod ução.

Do mesmo modo, os consumidore s tamkém serão beneficiados com a melhoria da comercialização, porquanto, expressando-se a maioria das falhas de uma comercialização inadequada por um aumento nos custos de operação e consequente aumento de preço do produto, sem tais inconvenientes, essas frutas se tornarão, desde logo, mais acessíve is à grande maioria da população.

Além disso, por serem as demais frutas aqui produzidas, comercializadas de modo idêntico e pelos mesmos canais que figos e uvas, ês ses outros produtos também se beneficiarão com qualquer melhoria, na comercialização dessas duas frutas; e essa maior eficiência na comercialização se tornará um grande incentivo para o estabelecimento de culturas comerciais de outras frutas, destinadas ao abastecimento do mercado interno, desenvolvimento êsse necessário e benéfico à coletividade.

Para campo dos nossos trabalhos escolhemos a zona de Valinhos e Louveira, não só devido aos seus caraterísticos, há pouco evidenciados, como também por considerarmos a zona como representativa das demais para o fim em vista. Além disso, considerando ser êste um dos primeiros trabalhos que se faz nesse sentido, o estudo da comercialização do figo e da uva apresenta a vantagem de ser bem mais simples que o da de outros produtos nossos, pois essas frutas já saem das mãos dos produtores em estado de serem utilizadas pelos consumidores, podendo dispensar muitos dos serviços da comercialização; e, ainda mais, as falhas que esta apresenta são, assim, mais fáceis de serem sanadas, quer pelos produtores e negociantes, quer pelo próprio Govêrno. A comercialização do figo e da uva foi estudada conjuntamente, não só porque em grande parte da zona essas duas culturas são encontradas nos mesmos sítios como por serem idênticos os seus agentes e sistemas de negócios $\left(^{\star}\right)$.

\section{MÉTODO ADOTADO}

Adotamos, neste estudo, o método de levantamento ("survey"), motivo por que fizemos, pessoalmente, uma série de visitas aos produtores, atacadistas $e$ retalhistas, inquirindo-os sôbre as diversas questões relacionadas à comercialização de figos e uvas. Procuramos entrevistar pro-

(*) Ao tratarmos de uva, no presente estudo, referimo-nos ùnicamente às uvas de mesa, pois as destinadas a vinho apresentam uma comercialização diferente e comportam um estudo à-parte. 
dutores e negociantes das mais variadas condições e bem distribuídos dentro do conjunto a ser estudado, de modo que os resultados obtidos fornecessem um quadro real da população pesquisada, ou, melhor, que a amostra fôsse representativa.

O métcdo prestcu-se perfeitamente ao estudo da comercialização $p \in l o s$ prcdutcres, tendo-se obtido, nesse setor, uma amostra bem representativa. Aresar de não haver uma estatística exata e atual do número de lavradores e de áreas plantadas com estas culturas, por informações cuidadosas que colhemos, acreditamos que os produtores entrevistados (em número de 58) representem $14 \%$ e $12 \%$ do total de plantadores de figo e uva, resrectivamente. Ccm relação à produção da zona, de que temos dados bem aproximados pelos despachos ferroviários, acreditamos que a nossa amostra representa $15 \%$ e $18 \%$ do total de figo e uva despachado.

Esste método mostrou-se igualmente satisfatório no estudo da comercialização pelos atacadistas de São Paulo, pois os negociantes entrevistados (em número de 8) representam $25 \%$ do total e podem ser considerados representativos da população.

Já no estudo da comerciâlização pelos retalhistas, o emprêgo dêste método de pesquisa foi apenas parcialmente satisfatório, por não quererem ou não poderem os negociantes fornecer dados essenciais ao estudo, como, por exemplo, o volume de vendas, as margens de negócios, os preços e as despesas. Além disso, quase nunca as informações eram sistematizadas, de acôrdo com o questionário que levamos, de modo que obtínhamos, de cada entrevistado, sòmente uma parte das informações que desejávamos. Por êsses motivos, os dados e fatos apurados foram suficientes apenas para se descrever, de um modo geral, como se processava a comercialização do retalho, sem que fôsse possível fazer referências quantitativas.

A pesquisa foi efetuada durante os anos de 1943 e 1944 ; os dados aqui apresentados sôbre a comercialização, pelos produtores, são de 1943, isto é, referentes à safra de 1942/43; os dados sôbre a comer. cializạção pelos atacadistas e retalhistas referem-se ao ano de 1944.

Além do levantamento ("survey") usamos outros métodos de pesquisa a fim de obter dados de que necessitávamos para completar a análise sôbre a comerciallização de figo e uva.

Assim, devido à falta de um serviço regular de coleta de preços dessas frutas, entramos em entendimento com alguns produtores e atacadistas para que anotassem, em cadernetas por nós fornecidas, os pre- 
̧̧os recebidos durante tôda a safra de 1943/44. Sòmente um produtor pôde executar êsse serviço e, assim mesmo, com falhas de algumas semanas e dias. Apesar disso, fomos obrigados a utilizar êsses dados por serem os únicos disponíveis e, também, por acreditarmos que, de um modo geral, êles não. se diferenciavam dos de grande número de produtores em condições análogas às do nosso informante. Com relação aos preços do atacado, conseguimos que três negociantes nos fornecessem individualmente êsses dados, com os quais calculamos a média de preços do atacado e que pode ser considerada representativa dêsse mercado, nessa safra.

Os preços do retalho foram por nós coletados diàriamente nas frutarias do centro da cidade, porém apenas os dados de uma frutaria (que faz parte de um "chain-store") mostraram-se com a sequência necessária para a utilização que tínhamos em vista. Considerando que eram relativamente constantes as diferenças entre os preços dos diversos estabelecimentos, julgamos razoável usar apenas os dados dessa única frutaria.

Devem, pois, ser levadas em consideração as limita̧̧ ões impostas pela exiguidade dêsses dados, quando dêles nos utilizarmos em nossa análise que, então, será feita mais em caráter de tentativa e como preliminar a estudos que se fizerem posteriormente com dados mais completos.

Finalmente, a fim de obtermos dados precisos sôbre a produção dessas frutas na zona, obtivemos da Companhia Paulista de Estradas de Ferro uma relação de embarques de figo e uva pelas suas estações na zona, durante os anos pesquisados ; êsses dados foram por nós condensados nos quadros XXIII a XXVI, que detalham os embarques por estações, praças de destino e por meses.

\section{CARATERÍSTICOS DOS PRODUTOS}

Da mesma forma que outros produtos, o figo e a uva apresentam certos caraterísticos que imprimem uma feição particular à sua comercialização.

Uma das particularidades destas duas frutas é que elas se conservam por pouco tempo em bom estado para consumo, uma vez maduras; por êsse motivo, a embalagem e o despacho da fruta são feitos dentro de poucas horas após a colheita ; todo êsse serviço é feito diàriamente pelos produtores, na primeira parte do dia. Uma vez chegadas as frutas aos centros atacadistas e retalhistas, elas têm que ser vendidas dentro de um ou dois dias, pois se ficarem mais tempo nas bancas se tornam "pas- 
sadas" e têm que concorrer desvantajosamente com as partidas mais frescas que chegam diàriamente.

Outra particularidade existente é que estas frutas são muito delicadas e não suportam muitas manipulações; devido a isso, passam elas pelos atacadistas, retalhistas e, muitas vêzes, até o consumidor final, com a mesma classificação e na embalagem original feita pelos produtores.

Mais do que para outras frutas nossas, o amadurecimento do figo e da uva é ràpidamente afetado pelas condições de tempo; as chuvas, por exemplo, concorrem para apressar o amadurecimento do figo, desde que o fruto já tenha alcançado um certo desenvolvimento. Dêste modo, nas semanas chuvosas, aumentam os embarques de figos, ainda que os produtores não gostem de colhêr fruta "chuvada", pois esta fica menos resistente e azeda com facilidade, sendo depreciada pelos negociantes.

Outro ponto importante a ser anotado, é a época e duração da safra destas frutas, pois, já que não suportam armazenamento comum, entram elas no comércio logo que são colhidas, e sofrem, portanto, a concorrência de outras produzidas na mesma época ou das que, suportando armazenamento, entram no mercado quando se apresenta a melhor ocasião.

A safra de uva na zona se inicia em meados de novembro e se prolonga até mais ou menos fins de fevereiro; a do figo se inicia na mesma época e vai até maio; de ano para ano ocorrem pequenas mudanças na época da maturação, segundo as condições de clima.

Com relação à uva, obtivemos dados dos produtores a respeito do início e fim de suas safras, dados êsses que estão condensados nos quadros I e II.

\section{QUADRO I}

DATAS DO INÍCIO DA SAFRA DE UVA POR LOCALIDADE E EM \% DE PRODUTORES

(Total de respostas : 48)

\begin{tabular}{|c|c|c|c|c|c|}
\hline \multirow{2}{*}{ LOCALIDADES } & \multirow{2}{*}{$\frac{\text { NOVEMBRO }}{\text { De } 15 \text { a } 30}$} & \multicolumn{2}{|c|}{ DEZEMBRO } & \multicolumn{2}{|c|}{ JANEIRO } \\
\hline & & De 1 a 15 & De 16 a 31 & De 1 a 15 & $\mathrm{De} 16$ a 31 \\
\hline Valinhos & 2,1 & 6,4 & 18,7 & 2,0 & 0,0 \\
\hline Rocinha & 2,1 & 0,0 & 14,6 & 2,0 & 0,0 \\
\hline Louveira ....... & 0,0 & 0,0 & 27,0 & 16,7 & 8,4 \\
\hline Tôda a zona & 4,2 & 6,4 & 60,3 & 20,7 & 8,4 \\
\hline
\end{tabular}




\section{QUADRO II}

DATAS DO TÉRMINO DA SAFRA DE UVA POR LOCALIDADE E EM \% DE PRODUTORES

(Total de respostas : 48)

\begin{tabular}{|c|c|c|c|c|c|}
\hline \multirow{2}{*}{ LOCALIDADES } & \multirow{2}{*}{$\frac{\text { DEZEMBRO }}{\text { De } 15 \text { a } 31}$} & \multicolumn{2}{|c|}{ JANEIRO } & \multicolumn{2}{|c|}{ FEVEREIRO } \\
\hline & & De 1 a 15 & De 16 a 31 & De 1 a 15 & De 16 a 28 \\
\hline $\begin{array}{l}\text { Valinhos } . . . . . \\
\text { Rocinha } . . . \ldots \\
\text { Louveira ....... } \\
\text { Tôda a zona.... }\end{array}$ & $\begin{array}{l}8,4 \\
0,0 \\
0,0 \\
8,4\end{array}$ & $\begin{array}{r}14,5 \\
2,1 \\
4,2 \\
20,8\end{array}$ & $\begin{array}{r}4,2 \\
6,2 \\
2,1 \\
12,5\end{array}$ & $\begin{array}{r}2,1 \\
6,2 \\
37,5 \\
45,8\end{array}$ & $\begin{array}{r}0,0 \\
2,1 \\
10,4 \\
12,5\end{array}$ \\
\hline
\end{tabular}

Vemos, por êsses quadros, que existem diferenças entre as épocas de safra nas diversas localidades consideradas, sendo Valinhos a zona mais precoce e onde, consequentemente, a safra termina mais cedo. Verifica-se, também, que a maioria dos produtores de uva inicia a remessa de seu produto ao mercado na $2 .^{a}$ quinzena de dezembro, diminuindo-a bastante da 2. ${ }^{\text {a }}$ quinzena de fevereiro em diante.

Outra informação que obtivemos dos produtores de uva foi a referente à duração de suas safras; êstes dados aparecem no quadro III, no qual os produtores estão agrupados em classes, segundo o número de dias de duração de suas safras ; o menor número encontrado foi de 10 e o maior 65 dias. Convém esclarecer que essa grande diferença na duração é devida, em grande parte, d̀s diferrentes variedades plantadas ; assim, a uva preta "Isabel", em geral, amadurece um pouco mais cedo que a "Niagara" e a uva "Corbina" (Seibel 2), também preta, em geral, amadurece depois da "Niagara". Dêsse modo, um plantador que cultiva a "Isabel", a "Niagara" e a "Corbina", terá a colheita de uva num período de tempo bem maior que o plantador que só cultiva uma dessas variedades.

\section{QUADRO III}

DURAÇAO DA SAFRA DE UVAS, EM DIAS POR LOCALIDADE E EM \% DE PRODUTORES

(Total de respostas : 48)

\begin{tabular}{|c|c|c|c|c|c|c|}
\hline LOCALIDADES & $\begin{array}{l}\text { Menos } \\
\text { de } 30 \\
\end{array}$ & 21 a 30 & 31 a 40 & 41 a 50 & 51 a 60 & $\begin{array}{l}\text { Mais } \\
\text { de } 61\end{array}$ \\
\hline $\begin{array}{l}\text { Valinhos } \ldots \ldots \ldots \ldots \\
\text { Rocinha } \ldots \ldots \ldots \ldots \\
\text { Louveira } \ldots \ldots \ldots \ldots \\
\text { Tôda a zona } \ldots \ldots \ldots\end{array}$ & $\begin{array}{r}14,6 \\
4,2 \\
2,1 \\
20,9\end{array}$ & $\begin{array}{r}10,5 \\
0,0 \\
16,5 \\
27,0\end{array}$ & $\begin{array}{r}2,1 \\
6,2 \\
6,2 \\
14,5\end{array}$ & $\begin{array}{r}0,0 \\
4,2 \\
14,7 \\
18,9\end{array}$ & $\begin{array}{r}2,1 \\
2,1 \\
12,4 \\
16,6\end{array}$ & $\begin{array}{l}0,0 \\
2,1 \\
0,0 \\
2,1\end{array}$ \\
\hline
\end{tabular}


Pode-se verificar que $81 \%$ dos plantadores terminam a safra em menos de 50 dias; durante êsse período, o plantador tem todo o tempo tomado em colhêr, embalar e despachar a fruta.

Quanto ao figo, não conseguimos obter, com os produtores, dados detalhados sôbre a duração de suas safras, em virtude de ter a pesquisa sido feita quando a safra ainda estava em curso.

Com os dados fornecidos pela Cia. Paulista de Estradas de Ferro - relativos aos embarques de figos e uvas, por meses e estações de embarque e de destino - e que estão condensados nos quadros XXIII a XXVI, pode-se avaliar melhor o desenvolvimento das safras dessas frutas na zona.

\section{ESBÔÇO DOS CANAIS DE DISTRIBUIÇÃO}

Antes de esturdamos detalhadamente a comercialização de uvas e figos, achamos útil esboçar, de modo rápido, os canais de distribuição dêstes produtos, isto é, o curso tomado pela mercadoria desde o produtor até o consumidor, a fim de que aquêles detalhes pudessem ser apreciados dentro de todo o conjunto.

Os produtores vendem sua fruta principalmente através de 2 classes de agentes de negócio: atacadistas e retalhistas. Os primeiros estão geralmente estabelecidos com bancas nos mercados de São Paulo e Rio de Janeiro e são os que apresentam maior volume de negócios com os produtores; alguns poucos negócios são também feitos pelos produtores, diretamente com consumidores e fábricas de doces.

Os sistemas de negócio usados pelos prołutores são principalmente dois : "à consignação" e a "preço fixado", isto é, um preço único, por unidade, fixado antes da colheita e para tôda a safra. O primeiro sistema é o mais comum.

Alguns dias antes da safra, os produtores são procurados, em seus sítios, por negociantes que se oferecem para vender a fruta num dos sistemas enunciados acima, especificando ainda outros detalhes, como o fornecimento de vasilhame, pagamento de carreto e frete, etc. As combinações feitas são verbais, na maioria dos casos.

Estabelecido, por exemplo, com um atacadista de São Paulo, um negócio pelo sistema "à consignação" com fornecimento de vasilhame pelo atacadista, no início da safra o produtor recebe uma certa quantidade de caixas vasias e rótulos impressos, para iniciar a remessa da fruta. Como os contratos são feitos geralmente na base de "fruta posta 


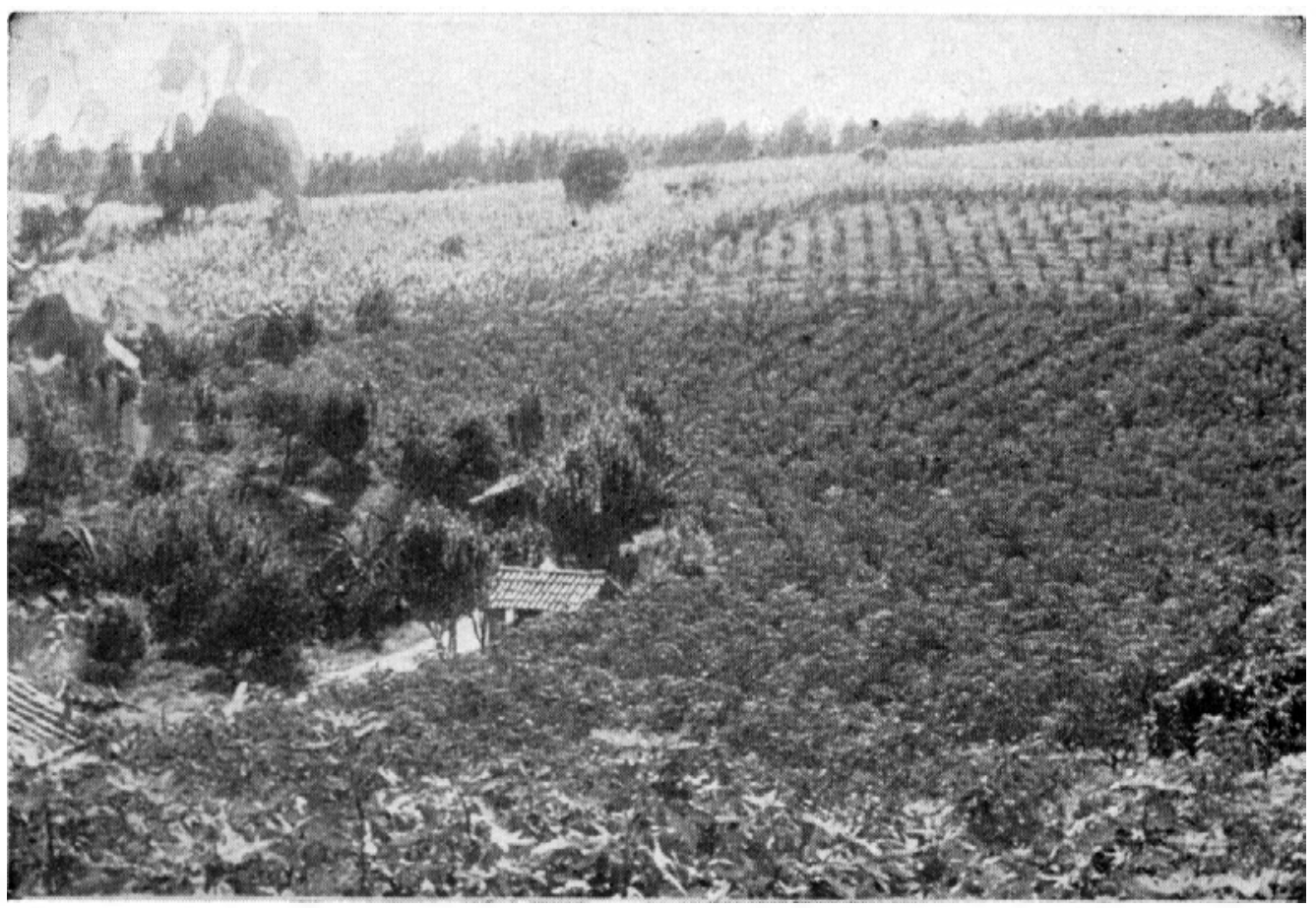

Fig. 1 - Um sítio de 5 alqueires com seu figueiral de 2.000 pésJ(Foto Paulo Cuba)

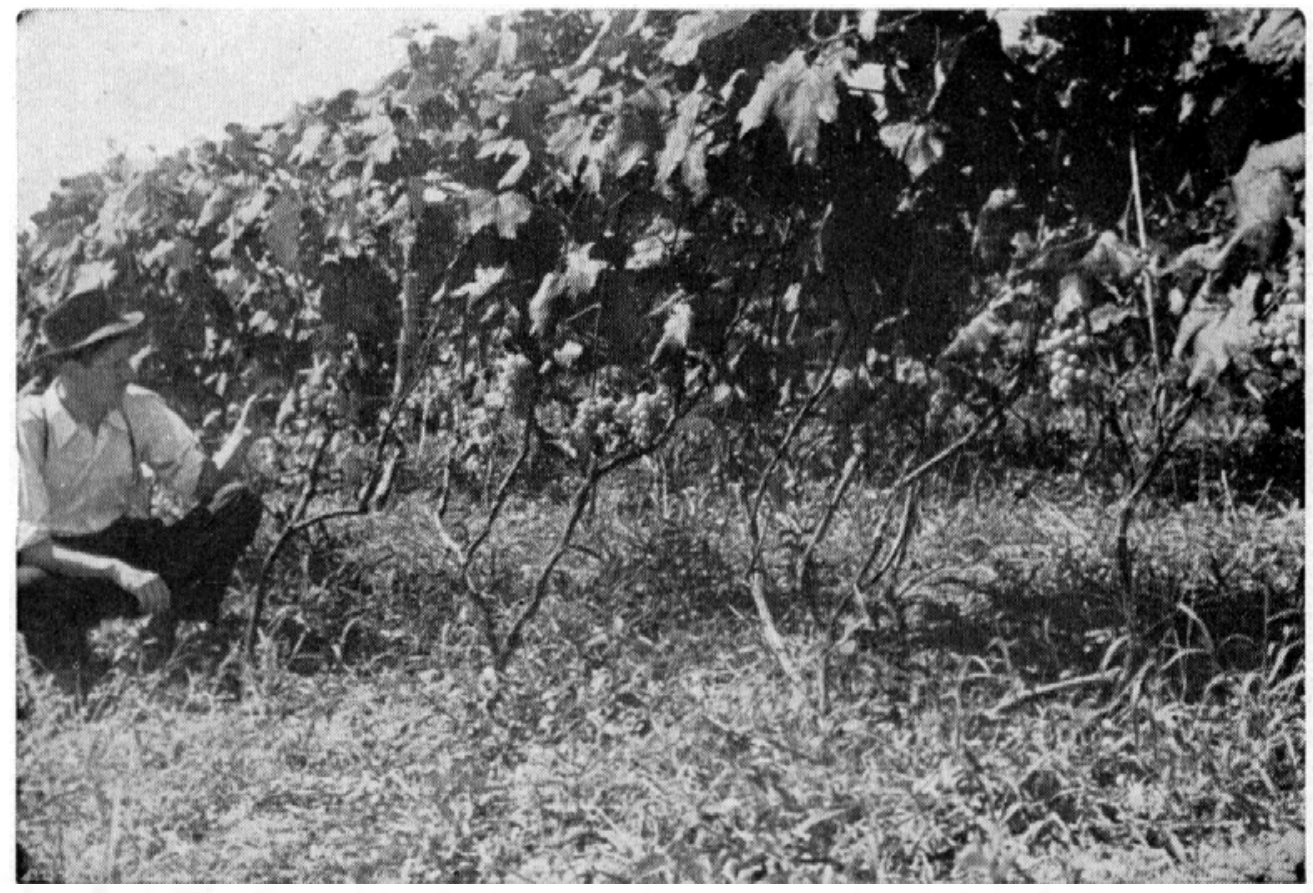

Fig. 2 - Esste virhedo de Niagara branca produz $2 \mathrm{Kg}$ de uva por pé. (Foto Paulo Cuba) 


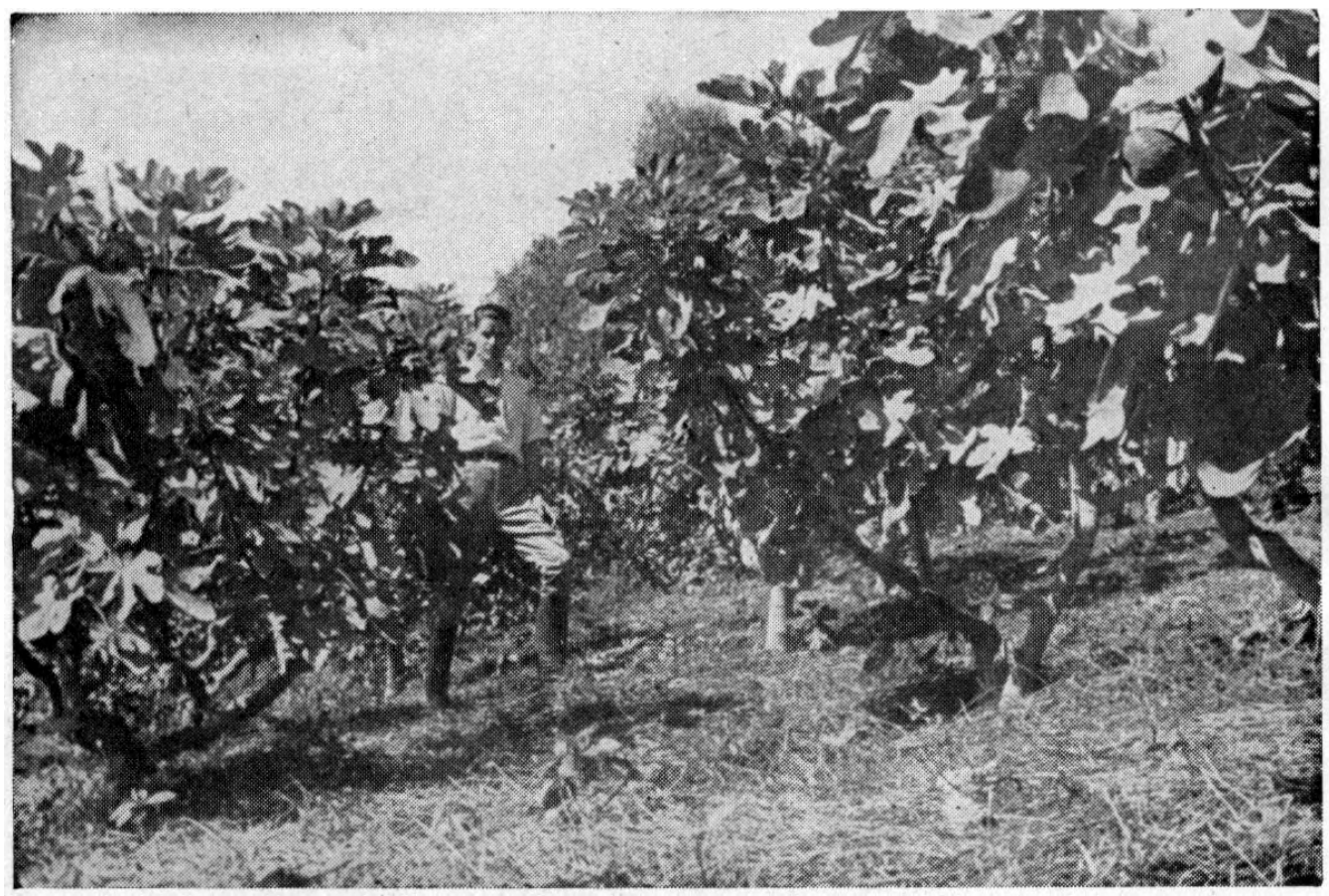

Fig. 3 - O solo do figueiral é inteiramente coberto por espêssa camada de matéria orgânica. (Foto Pâulo Cuba)

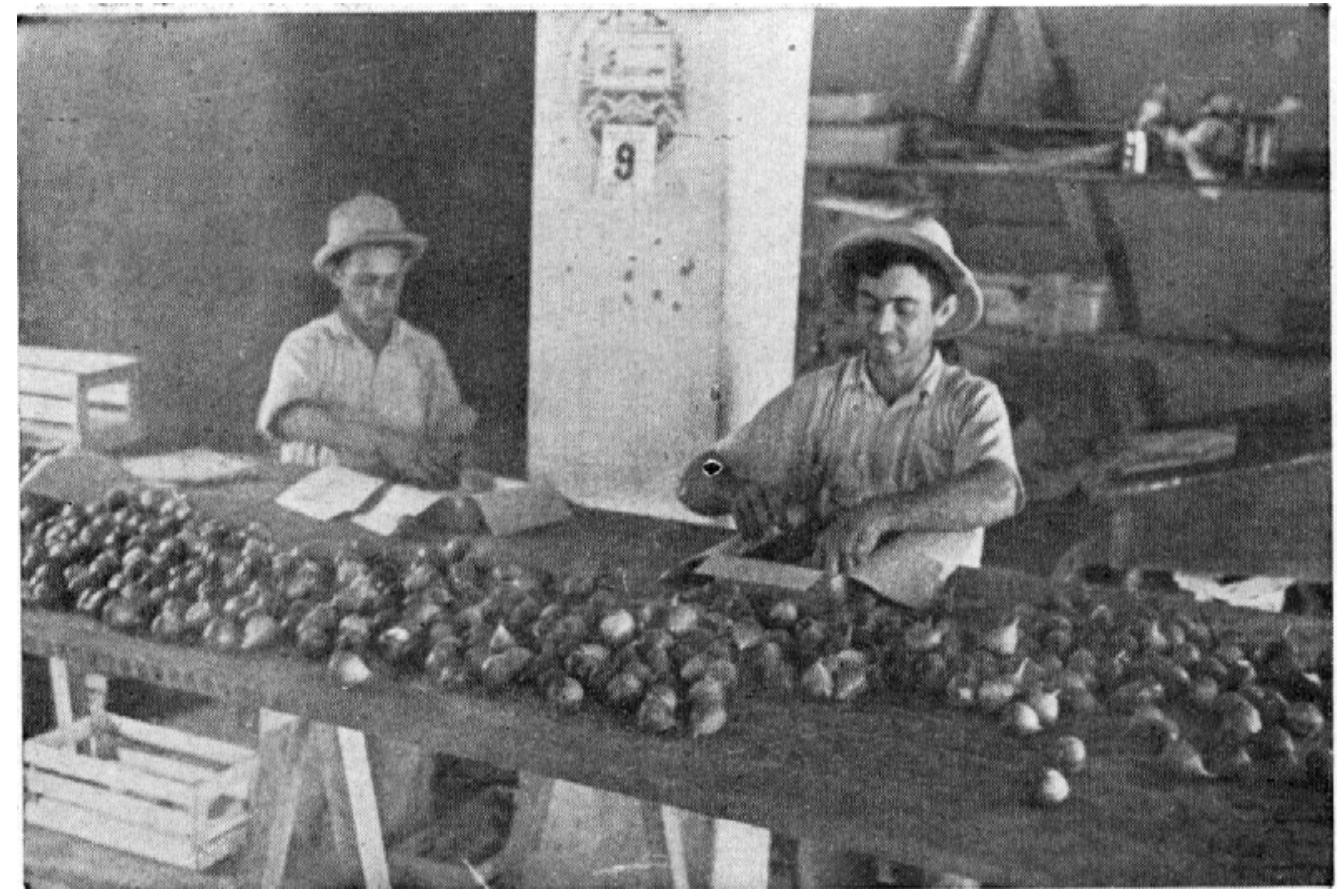

Fig. 4 - Logo após a colheita, os figos são colocados nas gavetas e estas nos engradados. (Foto Paulo Cuba) 
na banca do atacadista", é o produtor que leva a fruta à estação e paga o frete; o atacadista a retira no destino, descontando êste carreto em cada fatura que envia ao produtor, após a venda da partida. De tempos a tempos, quando necessita de dinheiro, ou no fim da safra, o produtor vai a São Paulo fazer o encontro de contas.

Idêntica é a marcha do negócio pelo sistema a "preço fixado"; sòmente, que o produtor, neste caso, não recebe fatura, pois não lhe interessa saber o preço que sua fruta alcançou na venda.

O atacadista de São Paulo, fazendo contratos de compra com diversos produtores, recebe diàriamente um número grande e variàvel de caixas de uva e engradados de figo que procura vender aos retalhistas seus fregueses; a maior parte da fruta é vendida no mesmo dia em que chega ao mercado. O atacadista negocia com os seguintes tipos de compradores: feirantes, fruteiros ambulantes, frutarias, hotéis e restaurantes e consumidores ; êstes compradores vão diàriamente às bancas dos atacadistas a fim de refazerem seus estoques. Os atacadistas vendem, em geral, a dinheiro, havendo regular percentagem de negócios a crédito verbal (fiado) e as unidades de vendas são caixas e engradados. A fruta é vendida no estado em que o atacadista a recebe do produtor.

A fruta comprada pelos retalhistas é por êstes transportada para seus lugares habituais de venda (feira, bairros, restaurantes, etc.) onde será adquirida pelos consumidores. Alguns retalhistas quase sempre fazem uma seleção na fruta que compraram, separando-a em classes de diferentes preços, e, quando a venda demora alguns dias, têm que ir separando e jogando fora as que se vão estragando. O retalhista, em geral, vende a uva a pêso e o figo às dúzias e gavetas, sendo a maior parte das transações feitas a dinheiro.

\section{COMERCIALIZAÇÃO PELOS PRODUTORES}

\section{Embalagem e Classificação}

Embalagem - Os vasilhames usados pelos produtores da zona para uva e figo, são, respectivamente, caixas e engradados. Êste vasilhame é de modêlo padrão e torna-se, dêsse modo, a unidade usada pelo produtor, na venda.

As caixas de uva têm as dimensões de 0,58x0,27 x 0,11 metros e são divididas no sentido da largura em 2 compartimentos ( $\left.{ }^{*}\right)$; em cada

(*) Encontramos sòmente um grande produtor usando caixas um pouco diferentes, com as dimensões de 0,53 × 0,28 $\times 0,11 \mathrm{~m}$ e sem divisão no sentido da largura. 
compartimento vão 2 camadas de uvas, separadas por uma fôlha de papel, que envolve completamente cada camada. $\bigcirc$ pêso bruto de uma caixa de uvas é de $10-11 \mathrm{~kg}$, contendo $8-9 \mathrm{~kg}$ de uva.

Os "engradados" de figo têm as dimensões de 0,44 x 0,24 × 0,25 metros e no seu interior são colocadas 3 gavetas com capacidade para um número variável de figos, de acôrdo com o tamanho dêstes: as disposições mais comuns dos figos nas gavetas são de 3, 4, 5 fileiras por $7,8,9,10$ carreiras. Cada gaveta é forrada e coberta por uma fôlha de papel. O pêso bruto, médio, do engradado de figos é de $8 \mathrm{~kg}$.

Tanto as caixas de uvas como as de figos são, de preferência, feitas de pinho do Paraná.

fornecimento do vasilhame é feito em alguns casos pelo agente, e, em outros, pelo produtor, e isto modifica bastante o aspecto do negócio, como se verá mais adiante. Pelos dados do nosso levantamento, em $71,4 \%$ dos casos, o agente de negócios foi o fornecedor do vasilhame. Se particularizarmos cada praça, como é feito no quadro IV, veremos que em São Paulo e Santos a grande maioria dos negócios é feita com vasilhame fornecido pelo agente, enquanto que, para o Rio e interior

\section{QUADRO IV}

FORNECEDORES DE VASILHAME SEGUNDO A PRAÇA DE DESTINO

E EM \% DE NEGÓCIOS REALIZADOS

(Total de respostas : 77)

\begin{tabular}{c|c|c|c|c}
\hline \multicolumn{1}{c|}{ Fornecedor } & S. Paulo & Rio & Santos & Interior \\
\hline Agente ........... & 87,0 & 8,3 & 100,0 & 42,8 \\
Produtor .......... & 13,0 & 91,7 & - & 57,2 \\
\hline
\end{tabular}

do Estado, o maior fornecedor do vasilhame é o produtor. Para o Rio, isso acontece devido à distância entre essa praça e o centro produtor, - que torna difícil regularizar a remessa periódica de caixas ao produtor. Para o interior do Estado, explica-se o fato de ser o produtor o maior fornecedor do vasilhame, pelo pequeno volume de negócios realizados nessas praças, havendo poucos agentes com organização para fornecimento do vasilhame. 
Pelo quadro $\mathrm{V}$ vemos que o fornecimento do vasilhame é independente do sistema de negócio usado, pois as percentagens encontradas para cada sistema são mais ou menos iguais à percentagem há pouco referida, relativa ao total de negócios.

\section{QUADRO V}

FORNECIMENTO DE VASILHAME SEGUNDO O SISTEMA DE NEGÓCIO EM \% DE NEGÓCIOS REALIZADOS

(Total de respostas : 77)

\begin{tabular}{|c|c|c|}
\hline Fornecedor & "à consignação" & "preço fixado" \\
\hline Agente .. & 74,4 & 67,0 \\
\hline Produtor & 25,6 & 33,0 \\
\hline
\end{tabular}

O papel de embalagem (papel manilha) é sempre fornecido pelo produtor e o seu custo variou de $\mathrm{Cr} \$ 39,00$ a $\mathrm{Cr} \$ 54,00$ a resma de 800 fôlhas; em cada caixa de uva vão $31 \frac{1}{2}$ fôlhas de papel e em cada gaveta de figo 1 fôlha, ou sejam 3 fôlhas por engradado.

Fm virtude do custo dos fretes, os produtores que fazem negócios com a praça do Rio não recebem o vasilhame de volta.

Classificação - A classificação é um dos pontos importantes na comercialização de qualquer produto. Infelizmente, não há padronização oficial para figos e uvas, de modo que o produtor classifica sua fruta segundo critério próprio, obedecendo às normas mais aceitas pelo comércio nas safras anteriores; há, entretanto, uma certa uniformidade nesse critério, o que permite indicar os pontos principais levados em conta nessa classificação.

Para a classificação da uva, os produtores consideram dois pontos: variedade e qualidade. Cada caixa contém uva de uma só variedade ( $\left.{ }^{*}\right)$.

(") As variedades plantadas na zona, são: Niagara branca e rosada, Barbera, Isabel, Golden Queen, Diamante Negro, etc. A Niagara branca é plantada pràticamente em tôdas as propriedades $\theta$ é a que entra com maior volume na produção total da região; a introdução da Niagara rosada é recente, estando os lavradores aumen. tando a sua plantação nestes 2 últimos anos; as uvas pretas (Barbera $\theta$ Corbina) foram plantadas quando os sitiantes faziam e vendiam uma apreciável quantidade de vinho, o que não é mais possível hoje por não poderem satisfazer às atuais exi- 
Como qualidade, os produtores consideram a homogeneidade no tamanho dos cachos e dos bagos, grau de amadurecimento, isenção de bagos estragados e manchados; segundo êstes pontos e para qualquer variedade, a uva é classificada em 3 tipos : 1.a, 2." e "descarte". Qualquer que seja o número de tipos, o produtor faz sempre uma limpesa prévia dos cachos, retirando, com uma tesoura, os bagos estragados. Como vemos pelo quadro VI, mais de $50 \%$ dos produtores só fazem 1 tipo.

Na classificação do figo, os produtores consideram os caraterísticos : tamanho e qualidade. Já vimos que o número de figos que uma

\section{QUADRO VI}

DISTRIBUIÇAO DOS PRODUTORES EM \%, SEGUNDO O NÚMERO DE TIPOS EM QUE CLASSIFICAM SUA FRUTA

$$
\text { (Total de respostas }\left\{\begin{array}{l}
\text { Figo }=25) \\
\text { Uva }=43 \text { ) }
\end{array}\right.
$$

\begin{tabular}{c|c|c}
\hline N.o de tipos (a) & F I G O & U V A \\
\hline & & \\
1 & 44,0 & 53,4 \\
3 & 52,0 & 39,5 \\
7,1
\end{tabular}

(a) Segundo a classificação descrita no texto.

gaveta pode conter varia com o tamanho dos frutos, de modo que êste é um fator que carateriza o engradado. Os produtores procuram arrumar nas gavetas de um engradado frutos do mesmo tamanho, de tal modo que fiquem bem ajustados uns aos outros e apresentem uniformidade no aspecto. O número mais comum de figos numa gaveta é de 28 , havendo produtores que quase só colhem frutos dêsse tamanho para menos.

gências sanitárias. Atualmente, esta uva é em parte vendida no comércio como uva de mesa, (apesar de valer bem menos que a Niagara branca) ou então vendida a cantinas da zona (em 1943 os fabricantes de vinho de Jundiaí pagaram Cr\$ 1,20 ○ $\mathrm{kg}$ de uva para vinho). É êste o motivo por que os produtores estão abandonando as plantações de uva preta para plantar variedades de mesa, como as Niagaras. A Niagara rosada apesar de ser idêntica à branca, em gôsto e qualidade, em geral vale um pouco mais que a branca. As duas últimas variedades, Golden Queen e Diamante Negro, sòmente são encontradas em poucos sítios e são vendidas por preços quase sempre superiores aos das Niagaras. 
Quanto à qualidade, os produtores levam em conta os seguintes pontos : grau e uniformidade de maturação dos frutos do mesmo engradado; frutos isentos de defeitos como bicada de pássaros, etc.

Levando em conta tamanho e qualidade, os produtores classificam o figo em 3 tipos : $1 .{ }^{a}, 2 .^{2}$ e "descarte" ; êste último é constituído de gavetas com frutos de tamanhos diversos, "passados" ou com bicadas de pássaros.

Como vemos pelo quadro VI, mais de $50 \%$ dos produtores classificam a sua safra de figo $\in m$ dois tipos que podem ser: $1 .{ }^{a}$ e 2. ${ }^{a}$, ou 1. a e descarte. Há ainda dcis tipos de fruta: a) "figo inchado", comprado pelas fábricas de doces e constituído de fruta não completamente madura, de côr vermelha ( $\left.{ }^{*}\right)$; b) - figo verde, também destinado à fabricação de doces.

Em geral, o comprador paga ao produtor um preço proporcional ao tipo da fruta, isto é, à classificação feita pelo produtor. Sòmente 12 plantadores de figo e 18 de uva responderam a uma nossa pergunta a respeito, e, por suas respostas, vimos que cêrca de $2 / 3$ dêles são faturados por preço proporcional à classificação feita.

Um ponto que deve ser anotado, desde já, é que as vendas de figo, pelo produtor, são baseadas em engradados, sem considerar o número de frutas em cada engradado, e a compra pelos consumidores é feita, em geral, baseada em dúzias e frações de dúzia de frutos, de modo que varia a unidade de negócio entre os diversos compradores. É verdade que há uma certa relação entre o preço que o produtor recebe por um engradado e o número de frutos que êsse engradado contém : engradados de gavetas com frutos médios, em geral valem mais que os engradados com maior número de frutos.

Outro ponto ligado à classificação, é o da marca da fruta do produtor. Sòmente 9,4\% dos plantadores inquiridos enviam a fruta com marca própria e pela qual já é conhecida nos mercados consumidores.

\section{TRANSPORTES}

A grande maioria da uva e figo desta zona é transportada para São Paulo e outras praças, por estrada de ferro; o transporte por estrada de rodagem, apesar de ser pequeno no momento atual em que a gasolina está fortemente racionada, tende a se tornar volumoso após a guerra, principalmente devido às ótimas condições da "via Anhanguera" que ligará São Paulo a Campinas.

(") O figo próprio para consumo apresenta côr vermelho-parda. 
Na época da safra de uva e figo, os produtores têm que fazer embarques diários de fruta e daí resulta que a distância entre os sítios e as estações de embarque é um ponto de importância neste comércio. A distância está, naturalmente, na dependência da qualidade das estradas e do meio de transporte usado; como em $90 \%$ dos casos a condução que êstes plantadores usam é a carrocinha puxada a um burro ("), conclui-se que êles não podem estar localizados a grandes distâncias das estações de embarque, apesar da existência de boas estradas de rodagem na zona. É isso, aliás, o que acontece, como vemos pelo quadro VII, - qual mostra que mais de $50 \%$ dos plantadores estão localizados a menos de $3 \mathrm{~km}$ das estações de Estrada de Ferro. A distância máxima encontrada foi de $9 \mathrm{~km}$.

\section{QUADRO VII \\ DISTÂNCIA DOS SITTIOS ÀS ESTAÇŌES}

(Total de respostas : 58)

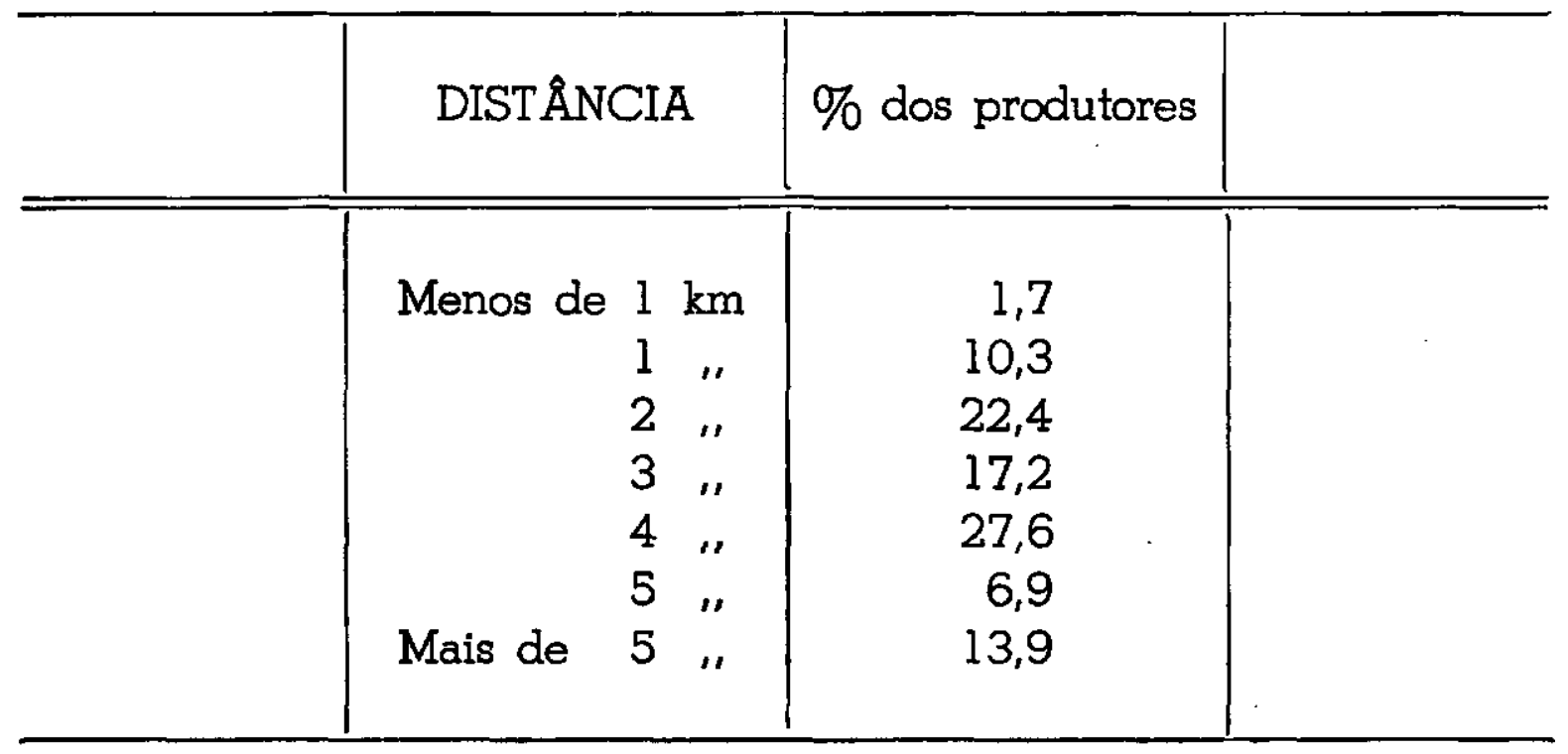

A questão do transporte ferroviário é vital para o comércio destas frutas, devido à facilidade com que elas se deterioram. Pequenos detalhes referentes ao transporte tornam-se pontos críticos para a boa marcha dêste comércio.

Inicialmente, temos o fato de que a fruta deve ser colhida e embarcada no mesmo dia, o que impossibilita o embarque nos primeiros trens

(*) A posse de uma carrocinha e um ou mais animais de tração $e$ típica dêstes produtores e 6 motivada principalmente por dois fatos: a obrigatoriedade de fazer viagens diárias à estação na época da safra e a necessidade de ser obtido estêrco para adubação das plantações. 
que passam por aquelas localidades. Quase todos os trens que param em Valinhos, Rocinha e Louveira carregam um pouco de fruta, mas os principais trens de embarque são os que saem de Campinas às 9,20 e 13,15 (trens de passageiros) e 20,30 (trem de carga), sendo êste último - que leva o grosso dos despachos para São Paulo e o único que pára nas estações de Horto e Corrupira. Em geral, o transporte nesse trem é feito em vagões da Companhia Paulista, próprios para frutas. As frutas para o Rio são embarcadas cedo $(9,20)$ e chegando à estação do Braz (S. P. R.) são baldeadas para o Norte (E. F. C. B.) e enviadas para o Rio pelo noturno das 19,00 horas do mesmo dia; isto é, gastam mais ou menos 24 horas em viagem. Se não fôsse a baldeação em São Paulo, que é demorada, a hora de embarque em Valinhos ou outra estação poderia ser retardada, com desafôgo para os plantadores, que teriam mais tempo para colheita, embalagem e despacho.

Sòmente os produtores que se utilizam da estação de Corrupira têm queixas quanto à hora de embarque, pois nesta estação só há carregamento de frutas no trem que sai de Campinas às 20,30 horas e êsse trem, muitas vêzes, só chega em Corrupira às 23-24,00 horas e como a estação dispõe de pouco pessoal e é exíguo o tempo de embarque, são os próprios produtores que carregam o vagão, com o fim de evitarem atropêlo dos empregados e conseqùente mau trato dos volumes.

Queixaram-se da demora no transporte $85 \%$ dos plantadores, tendo sido relatados casos de despachos que levaram até 4 dias para chegar ao Pari (São Paulo). Nessas condições, a fruła chegou, muitas vêzes, às mãos dos agentes em mau estado, justificando rebaixamento no preço do dia, com o que geralmente os produtores não querem concordar, uma vez que a embarcaram em boas condições. Não foi possível determinar a causa e os causadores dessa demora, porque o trajeto citado é coberto por mais de uma estrada de ferro, sendo difícil apurar a quem cabe a culpa. Para o Rio, também houve muitas queixas quanto a atrasos no transporte e, como se poderá prever, com consequências maiores devido à maior distância e às baldeações.

Outro ponto referente ao transporte, é o que diz respeito ao tipo de vagão empregado: na maioria dos casos, os vagões são impróprios para trutas de fácil deterioração como a uva e o figo, sendo mesmo uma grande parte delas transportada em vagões-gaiolas; êstes têm a única vantagem de serem de pequena tonelagem (Lotação-12.000 kg) e poderem ser ligados a qualquer composição, ao contrário dos vagões de frutas da Companhia Paulista que são de maior tonelagem (Lotação = $30.000 \mathrm{~kg}$ ) e quase só são ligados aos trens de carga. 
Tamkém tem havido queixas quanto à excessiva altura das pilhas de volumes dentro do vagão, havendo ruptura de caixas que se encontram nas camadas inferiores e conseqùente esmagamento de frutas; tamkém do empilhamento mal feito tem resultado muitos desabamentos nas paradas bruscas e desengates de vagões.

Outro fator responsável por muitos prejuizos é a falta de cuidado no manuseio dos volumes de frutas pelos empregados das Estradas, nos embarques e baldeações (principalmente nestas últimas). Pela natureza delicada destas frutas, pode-se imaginar os prejuizos ocasionados por êste desleixo. Para evidenciar a importância da questão, basta dizer que produtores que enviam uva e figo para o Rio, pagam a uma pessoa em São Paulo Cr\$ 0,50, por volume, para tiscalizar a baldeação da fruta, da estação do Braz (S. P. R.) para a do Norte (E. F. C. B.), a fim de impedir que as caixas sejam maltratadas. Para evitar os inconvenientes dessa baldeação, os produtores que enviam fruta para o Rio pediram, em novembro de 1942, que fôsse fornecido diàriamente um vagão da E. F. C. B. até Louveira, para fazerem o embarque direto àquela praça, porém o pedido só foi atendido em meados de fevereiro de 1943, quando já estava pràticamente terminada a safra de uva na zona.

Estas questc̃es de demora no transporte e estragos durante o mesmo, são muito importantes, principalmente para o produtor que é quem corre êsses riscos, fato de que pode aproveitar-se algum agente para depreciar a fruta nas faturas que envia ao produtor; e êste não tem recurso algum de defesa, mesmo porque as estradas de ferro só aceitam despachos de frutas frescas, isentando-se de responsabilidade pela sua deterioração.

Outra queixa que os produtores revelam quanto às estradas, é a deficiência de pessoal e de material em certas estações, como Rocinha e Corrupira; não só o despacho se torna demorado, com perda de tempo para os produtores, como também há maior risco, por falta de lugar abrigado para as frutas que aguardam carregamento.

Com referência aos fretes, há um ponto a anotar: os despachos de volumes até $48 \mathrm{~kg}$ de pêso total, de Valinhos, por exemplo, a São Paulo, pagam um frete fixo de $\operatorname{Cr} \$ 2,00$; para despachos de mais de $48 \mathrm{~kg}$ é cobrado mais ou menos $\operatorname{Cr} \$ 0,06\left(^{*}\right)$ por $\mathrm{kg}$ adicional; se considerarmos um produtor que despacha diàriamente $20,30,50$ ou mais volumes, concluiremos que êste frete é razoável ; se lembrarmos, porém,

(*) Como é complexo o cálculo de fretes, tomamos um despacho de $60 \mathrm{Kg}$, para chegar à quantia acima. 
que a grande maioria dos produtores é constituída por pequenos sitiantes que, em geral, embarcam sòmente 2, 3, 4 caixas de uvas ou de figos por dia, concluiremos que êsse frete vem pesar bastante no custo por caixa. Ora, como a despesa de frete, na maioria dos casos, corre por conta dos plantadores, êste aumento de custo por caixa recai sòmente sôbre o pequeno produtor, que vê assim diminuída sua margem de lucro (*)

As dificuldades de transporte são um dos motivos que concorrem para a pequena venda no interior do Estado, pois não só a demora nas viagens como também a falta de cuidado nas baldeações fazem com que a fruta chegue ao destino "passada" e estragada, o que não anima os produtores e agentes a ter negócios com essas praças.

\section{VENDA}

Agentes de venda - $\bigcirc$ produtor vende sòmente uma pequena quantidade de fruta diretamente aos consumidores; o maior volume da produção entra no mercado por intermédio de agentes de negócios ou sejam atacadistas, retalhistas, produtores-revendedores, fábricas de doces, de vinagre, etc. Para maior facilidade de exposição, vamos grupar êsses agentes em quatro classes:

1.0 - Atacadistas

$2 .^{\circ}$ - Retalhistas

3. ${ }^{\circ}$ - Diversos

$4 .^{\circ}$ - Consumidores

Damos o nome de atacadistas a alguns dos negociantes de frutas estabelecidos nos Mercados Municipais de São Paulo e Rio de Janeiro, que recebem e reunem no mesmo dia lotes de frutas de diversos produtores e os repartem, por venda, entre os retalhistas. Pela execução dêstes serviços e mais, pelo papel preponderante que tomam na determinação do preço do dia, funçc̃es estas próprias dos negociantes atacadistas, acreditamos poder chamá-los por esta forma $\left(^{* *}\right)$. Êstes atacadistas, ou "barraqueiros", como são mais comumente châmados, além

(*) Devemos anotar aqui que, em 1944, houve majoração geral nos fretes ferroviários, prejudicando bastante o comércio destas frutas. (Ver nota à fágina 110).

(**) Entretanto, oficialmente, êles são chamados retalhistas, porque, por uma lei municipal, todos os arrendatários de bancas no Mercado são obrigados a vender a retalho, sempre que solicitados; como alguns dêstes negociantes se especializaram no atacado, sua venda a retalho é nula. 
de uva e figo, geralmente negociam com outras frutas, alguns legumes e, às vêzes, ovos.

Chamamos retalhistas aos proprietários de mercearias, frutarias, feirantes, ambulantes, etc., das cidades de São Paulo, Rio de Janeiro, Santos e interior. Apesar de a função principal dos retalhistas ser a de servir de intermediários entre os atacadistas e consumidores, alguns dêles negociam diretamente com os produtores.

Grupamos sob o título diversos, certos tipos de compradores, como: produtores-revendedores, isto é, alguns produtores que compram frutas de outros produtores para as revender sob seu nome no Mercado; fábricas de doce, fábricas de vinagre, etc..

Alguns produtores costumam vender uma pequena parte de sua produção diretamente a consumidores, em geral conhecidos seus que fazem periòdicamente um pedido de frutas; também se inclui aqui a venda de frutas à margem das estradas de rodagem, a compradores ocasionais.

Convém notar que estas distinções que fizemos entre os tipos de agentes indicam sòmente as tendências mais fortes de sua função e modo de negociar e não excluem a possibilidade de que êles exerçam outras atividades em menor escala.

Durante a mesma safra, os produtores podem enviar a fruta a mais de um agente de negócios; êsse ponto foi objeto de uma pergunta em nosso inquérito e as respostas aparecem no quadro VIII, no qual vemos que $62,6 \%$ dos produtores enviam a fruta para um único agente durante a safra, a metade dêstes $62,6 \%$ é constituída de produtores que

\section{QUADRO VIII}

DISTRIBUIÇAO DOS PRODUTORES SEGUNDO O NÚMERO DE AGENTES COM QUEM NEGOCIAM SUAS SAFRAS, EM \%

(Total de respostas : 56)

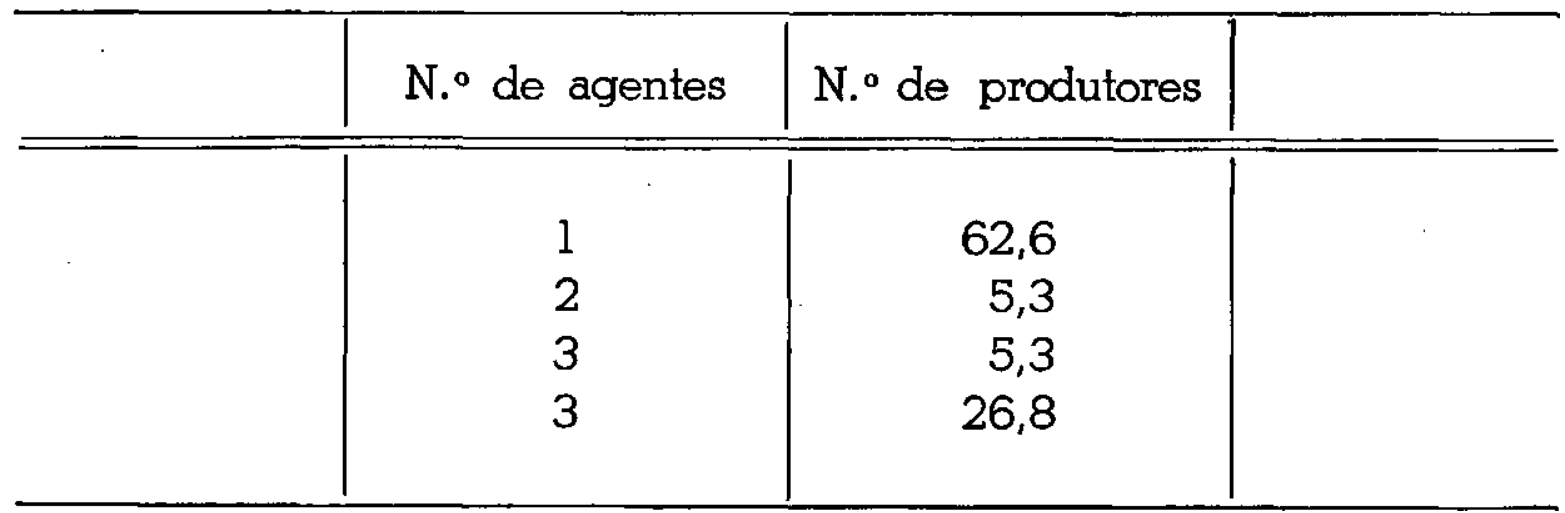


fizeram negócios a "preço fixado" (quase 90\% dos produtores que fizeram negócio neste sistema enviaram a fruta a um único comprador). Os produtores enviam a fruta em consignação a mais de um agente, numa tentativa de alcançarem melhores preços; assim é que enviam no mesmo dia partidas de frutas a dois ou mais agentes e verificam, ao receberem as faturas, dois ou tres dias mais tarde, quais os agentes que lhes faturaram maior preço; na próxima remessa, então, êles consignam uma quantidade maior para êsses agentes. Entretanto, o que geralmente acontece é que nesta remessa o agente já fatura o menor preço. Dessa forma, os produtores vivem despachando maiores partidas, ora a um ora a outro agente, numa justificável, mas quase sempre inútil procura de melhores preços.

Apesar de, em geral, os produtores afirmarem que não estão satisfeitos com seus agentes de negócios, por acharem que não recebem por sua fruta o preço devido, podemos ver no quadro IX que sòmente $23 \%$ dos produtores mudam todos os anos de agente, à procura de um que satisfaça seus desejos de segurança no comércio. Esta aparente contradição pode ser em parte explicada pela pequena concorrência que há entre os agentes, pois, oferecendo êstes as mesmas bases de negócios, os produtores ficam sem alternativa de escolha. Incluimos na classe

\section{QUADRO IX}

HA QUANTOS ANOS OS PRODUTORES NEGOCIAM COM OS MESMOS AGENTES

(Total de respostas : 52)

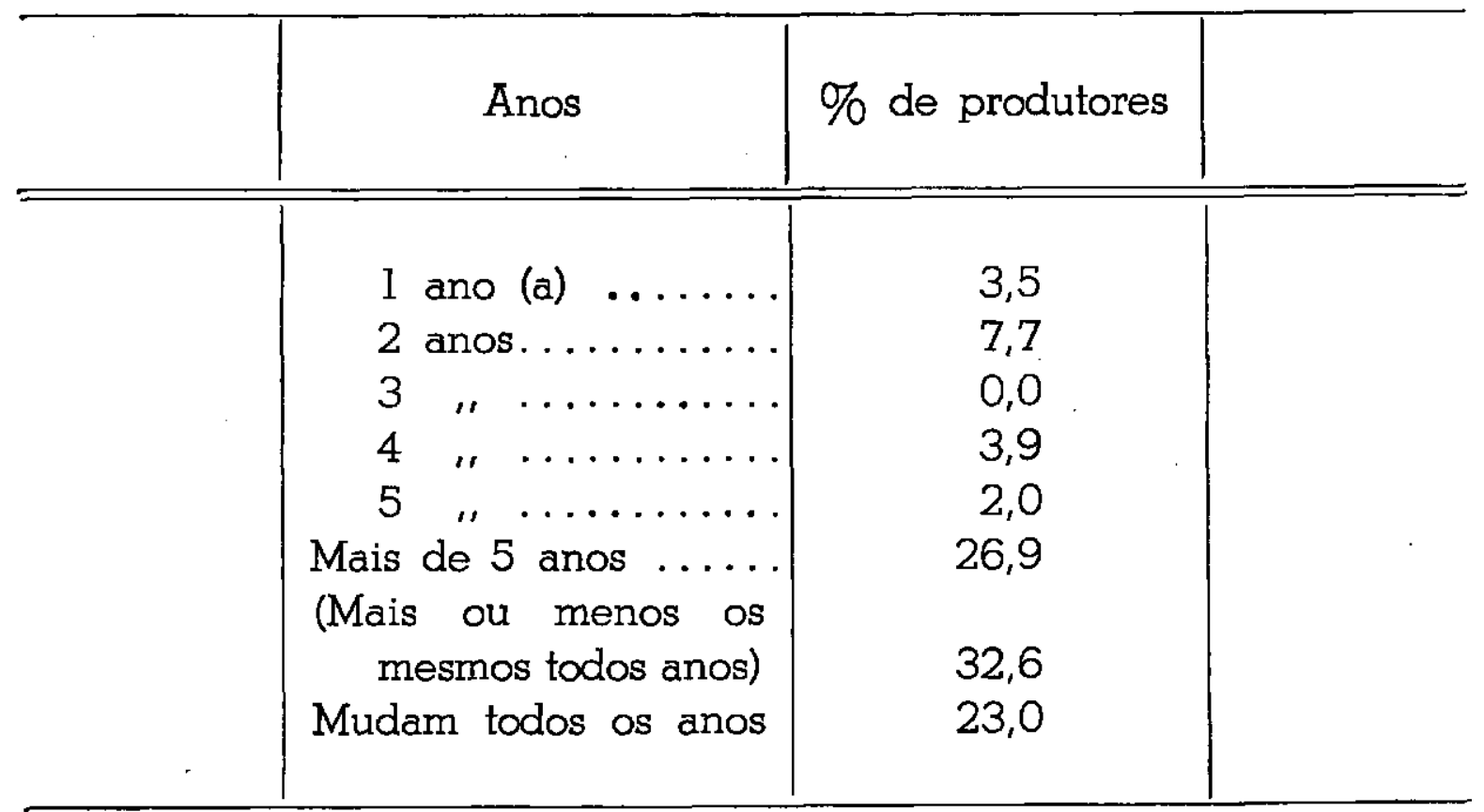

(a) Plantadores que colheram êste ano sua $1 .^{\mathbf{a}}$ safra. 
"mais ou menos os mesmos todos os anos" aquêles produtores que dentro de um grupo de agentes conhecidos enviam a fruta cada ano a um certo número dêsse grupo, fazendo uma espécie de rodízio entre êles : o número de anos que um dêsses agentes negocia com o produtor varia com a satisfação com que o produtor terminou a última safra com êle.

Um ponto interessante que procuramos esclarecer durante o nosso inquérito, é o relativo às razões pelas quais os produtores escolhem os agentes de negócio; as respostas que obtivemos estão condensadas no quadro $X$, no qual essas razões aparecem nos mesmos têrmos em que nos foram dadas. Como vemos, ..... Preço e Honestidade .... foram os principais motivos invocados pelos produtores. Quando o produtor diz que escolhe o agente por uma questão de --- Preço - é preciso acentuar que êle geralmente se refere à prática, descrita há pouco, de enviar a fruta para o agerte que está faturando por melhor preço na ocasião; a não ser que seja o caso de negócio a "preço fixado", no qual o produtor escolhe o agente que apresentar melhor oferta. É significativo que $35,8 \%$ dos produtores' escolham os agentes pela honestidade que demonstram no negócio, o que bem revela como é encarada, por êles, a questão do comércio da fruta.

\section{QUADRO X}

MOTIVOS PEIOS QUAIS OS PRODUTORES ESCOLHEM OS AGENTES DE NEGÓCIOS, EM \%

(Total de respostas : 53)

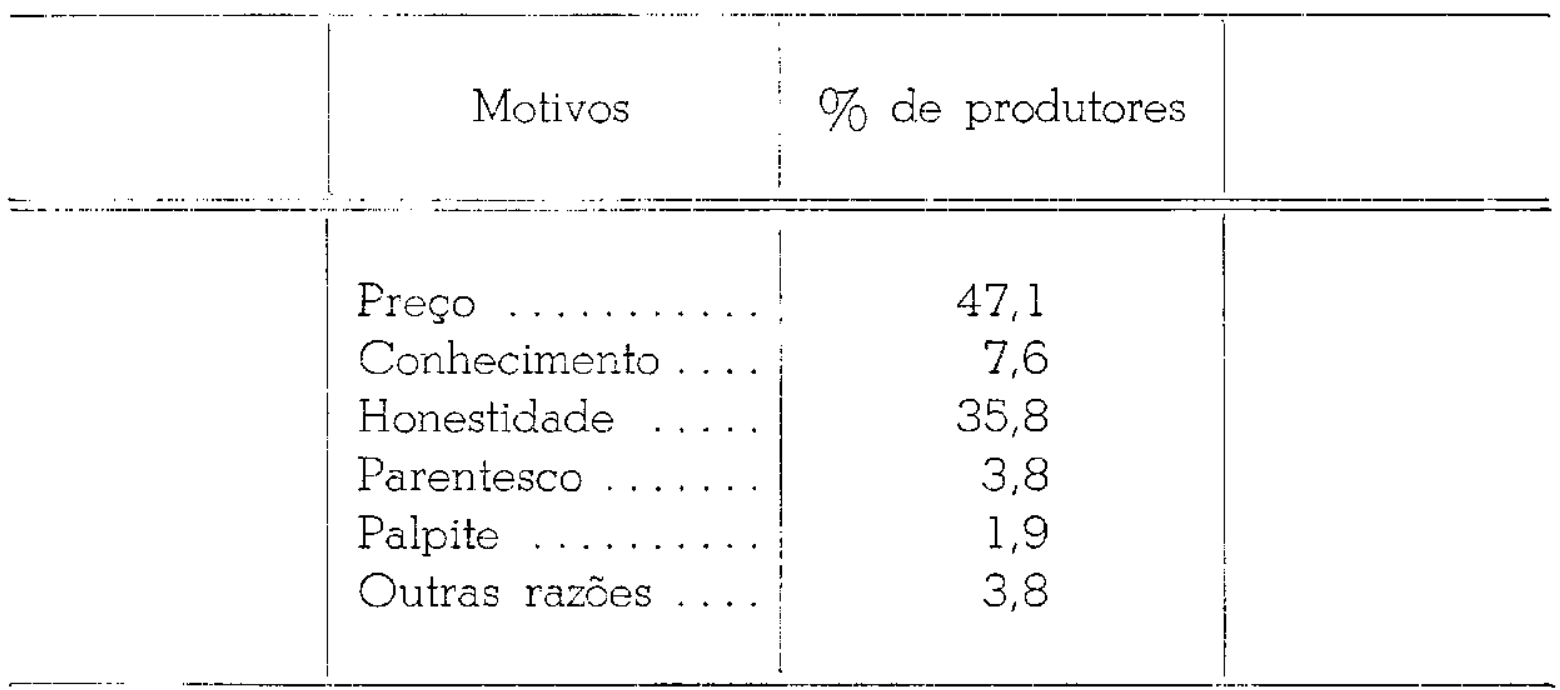

Sistemas de negócio -... São dois os sistemas de negócio usados pelos produtores no comércio destas frutas : à "consignação" e a "preço fixado". Quando o produtor envia a fruta à consignação, o atacadista a recebe e vende pelo melhor preço que alcançar na praça; dêsse 
preço, que chamaremos preço bruto, o atacadista deduz as despesas que teve (carretos, amortização de vasilhame, frete de retôrno dêste, etc.) e mais uma comissão por seu serviço; o que resta é o preço líquido, pelo qual a fruta é faturada ao produtor. $O$ sistema chamado a "preço fixado" é aquêle em que o produtor faz um contrato com um negociante para lhe vender tôda ou parte de sua produção a um preço único, por unidade, preço êsse geralmente determinado antes da safra.

Os produtores negociam com os atacadistas, retalhistas e plantadores-revendedores por qualquer um dêstes dois sistemas, conforme suas. conveniências; porém com as fábricas de doces, de vinagre e consumidores êles só negociam a "preço fixado".

As percentagens de negócios dos produtores com cada um dos tipos de agentes e sistemas de negócio são mostradas no quadro XI e por êle vemos que quase $90 \%$ dos produtores vendem a fruta por intermédio dos atacadistas. Quanto aos sistemas de negócio, vemos que $62,4 \%$ dos produtores negociam à consignação e 33,7\% vendem a "preço fixado". Tomados isoladamente a uva e o figo, encontramos as seguintes percentagens para cada sistema de negócio: da safra de uva, $61,2 \%$ são negociados à consignação e 38,0\% a "preço fixado"; da safra de figo, as percentagens são, respectivamente, 70,5\% e 29,5\%.

\section{QUADRO XI}

DISTRIBUIÇAO DOS NEGÓCIOS DOS PRODUTORES SEGUNDO OS AGENTES DE VENDA E SISTEMAS DE NEGÓCIO, EM \%

(Total de respostas : 77 )

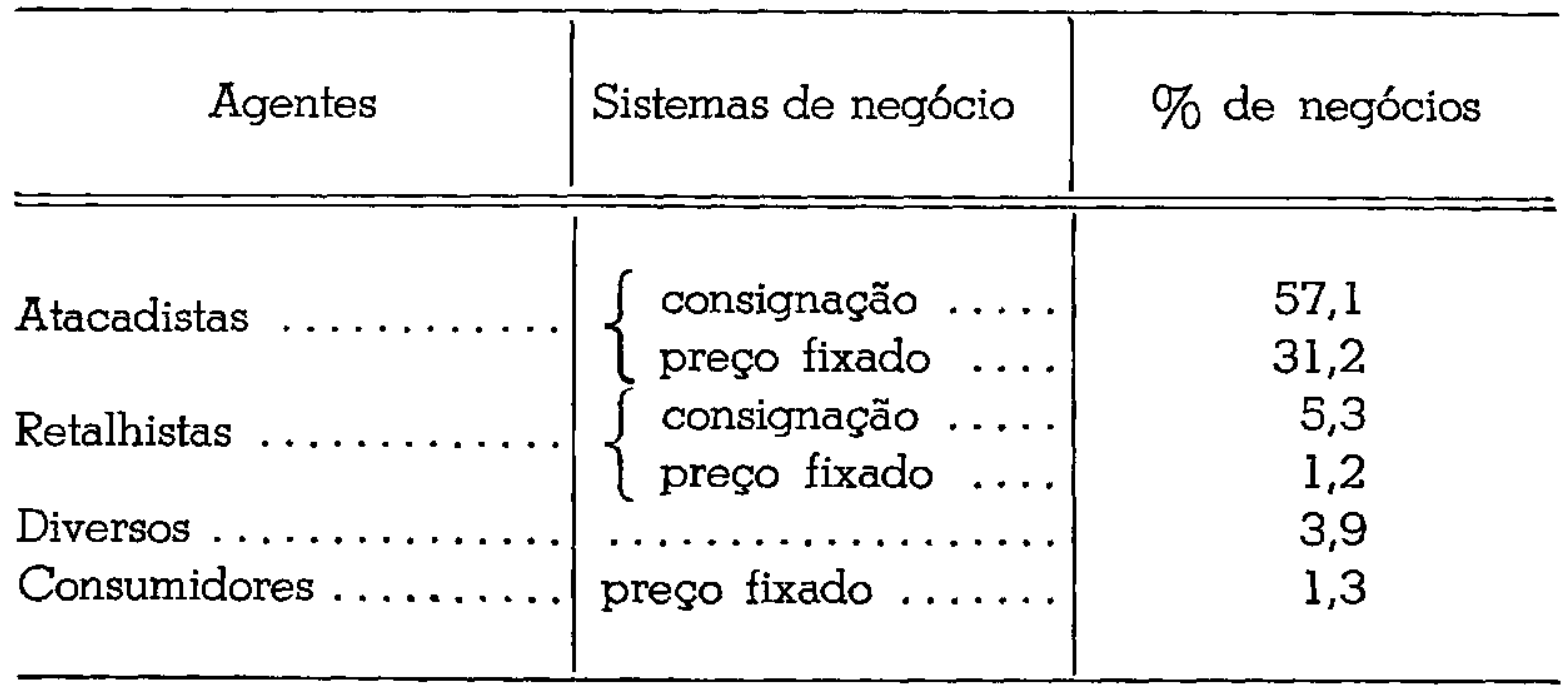

Estas percentagens mostram que os produtores negociam mais ou menos $2 / 3$ de suas safras de uva e figo pelo sistema à consignação. A preferência por êste sistema é determinada mais pelos atacadistas do 
que pelos produtores, o que aliás é explicável, pois, recebendo a fruta à consignação, os atacadistas não correm o risco de deterioração durante ou após o transporte, encalhe na banca e flutuação de preços. Apesar de correrem êsses riscos por conta dos produtores, muitos dêstes também preferem êsse sistema de negócio, por lhes permitir esperar maiores lucros por ocasião da alta dos preços no mercado. Entretanto, êsse sistema apresenta grandes desvantagens para os produtores, como veremos logo mais.

Os produtores que não querem correr o risco de variação de preços, preferem negociar felo sistema a "preço fixado" ; ainda que não possam beneficiar-se com um lucro maior na alta dos preços, obtêm uma situação mais estável e segura. Não são muitos os atacadistas que querem negociar nesta base, pois não podendo prever como se desenvolverá a safra e, portanto, seus preços, o risco que correm será naturalmente grande, a não ser que se resguardem fazendo contratos a "preço fixado" com os retalhistas, o que não é usado. Por êsse motivo, os preços que os atacadistas oferecem para negociar neste sistema não são, em geral, altos. O número de atacadistas que fazem negócio a "preço fixado" varia de acôrdo com o ano; assim, quando calculam que a safra será pequena, há maior número de negócios a "preço fixado", pois os atacadistas, antevendo que será um ano de boas perspectivas de vendas, oferecem um preço convidativo ao produtor; também negociam neste sistema, quando sabem que determinado produtor terá uma safra precoce, pois a fruta entrará no mercado em época de escassez e, portanto, alcançará preços altos. Os atacadistas só fazem negócios a "preço fixado" com produtores bem conhecidos e, muitas vêzes, só depois que a fruta começa a chegar ao mercado, quando então podem verificar sua qualidade, pois mesmo bons produtores não podem apresentar um bom artigo quando o tempo corre mal.

Apesar de maior segurança que traz aos produtores, êstes apresentam diversas queixas contra o sistema a "preço fixado". Entre essas queixas, a mais comum é a seguinte : quando o mercado está abarrotado de frutas e os preços caem abaixo dos fixados, o atacadista, que, geralmente, é o fornecedor do vasilhame, suspende temporàriamente sua remessa ao produtor, que fica impossibilitado de colhêr e enviar a fruta ao mercado, perdendo-a no pé; o atacadista evita, dêste modo, receber fruta que teria que vender com prejuizo. Se o produtor tiver meios e oportunidade, poderá defender-se comprando vasilhame de algum vizinho no qual enviará a fruta; outros, para evitar êsse inconveniente, exigem do comprador um depósito de determinada quantia em dinheiro 
para cobrir o decorrente de um eventual atraso na remessa do vasilhame. Outra queixa que os produtores têm dêste sistema, é que muitos atacadistas pedem, no fim da safra, um abatimento no preço prèviamente fixado, alegando terem tido prejuizos em virtude de imprevistos de tempo, atrasos no transporte, etc.; os produtores geralmente concordam com o pedido, porque, além de não terem feito um contrato escrito, querem liquidar as contas de qualquer maneira, pois, no geral, estão precisando de dinheiro nessa ocasião.

Por outro lado, os atacadistas alegam não fazerem maior número de negócios a "preço fixado" por sofrerem muitos prejuizos devido à má fé de certos produtores; nesse sentido, dizem que quando o preço da fruta no mercado está abaixo do estipulado num negócio a "preço fixado", o produtor, que negociou por esta forma, compra truta do vizinho ao preço do dia e a envia ao atacadista como se fôsse sua, ganhando assim a diferença; quando o preço do mercado está acima do fixado, êle desvia uma parte de sua fruta, enviando-a à consignação a outro atacadista e ganhando, também aqui, a diferença. Outra alegação dos atacadistas, é que certos produtores, uma vez feito ajuste a "preço fixado", desleixam no trato e embalagem da fruta, de modo que esta chega em más condições ao Mercado e é vendida com prejuizo.

Os negócios a "preço fixado" são feitos para fruta de uma só qualidade, geralmente a de primeira, e a fruta pior o produtor vende à consignação a outros atacadistas. (*)

Nos negócios à consignação, o produtor entrega a fruta na estação de destino; quando o negócio é a "preço fixado" pode variar o lugar

\section{QUADRO XII}

LUGAR DE ENTREGA DA FRUTA PELOS PRODUTORES

(Total de respostas : 53)

Lugar

$\%$ dos produtores

Estação de destino $\ldots \ldots \ldots \ldots$
Estação de embarque $\ldots \ldots \ldots$
No sítio $\ldots \ldots \ldots \ldots \ldots \ldots \ldots \ldots$

92,7
5,7
1,9

(*) Encontramos um produtor que fêz um contrato interessante, pois vendeu sua uva ao preşo fixado de $\operatorname{Cr} \$ 16,50$, tanto a de $1 .{ }^{2}$ como a de $2 . "$, mas com a condição imposta pelo comprador, que a fruta de $2 .^{a}$ não ultrapassasse de $7 \%$ da de $1 . .^{\text {; }}$; se a $\%$ de fruta de 2.a fôsse maior que a combinada, o produtor receberia sòmente $\operatorname{Cr} \$ 10,00$ por essa qualidade. 
da entrega. Como vemos pelo quadro XII, a quase totalidade dos produtores entrega a mercadoria na estação de destino, de modo que ficam a seu cargo as despesas de carreto à estação e o frete; como se verá mais adiante, nos negócios à consignação, o carreto da estação de destino à banca do agente, serviço executado por êste último, também corre por conta do produtor. Encontramos uma pequena percentagem de produtores que vendem a fruta no sítio; um grupo de sitiantes vizinhos, que negociaram suas safras com um único comprador que fazia diàriamente uma viagem de caminhão de São Paulo aos sítios, a fim de transportar a fruta.

Um serviço que muitos atacadistas prestam aos produtores é o adiantamento de várias quantias para custear diversas despesas da entresafra. Pelos dados do nosso "survey" verificamos que $75 \%$ dos atacadistas tinham diversas quantias emprestadas aos produtores. Este serviço é prestado de uma forma bastante primitiva, pois não há uma determinação de praso, nem assinatura de algum documento por parte do tomador de empréstimo; a maioria dos atacadistas não cobra juros e o pagamento da dívida é sempre por desconto no valor da fruta que o produtor se compromete enviar ao atacadista que o financiou.

Prestação de contas - $A$ forma pela qual se dá o ajuste de contas entre produtores e agentes de negócio depende do sistema usado. Quando o negócio é a "preço fixado", o produtor guarda o conhecimento. de embarque de cada partida e ùnicamente com êste documento é que faz o encontro de contas com o atacadista durante ou no fim da safra ; a única coisa que lhe interessa saber é o número de volumes enviados, já que o preço unitário de cada volume foi anteriormente fixado.

Quando, porém, o produtor negocia à consignação, é de seu interêsse. saber, não só o número de caixas e engradados despachados, como também o preço pelo qual foram vendidos. Por êsse motivo, além dos conhecimentos da Estrada, o produtor também guarda as faturas que o agente sempre lhe remete após a venda de cada partida recebida.

A única informação que os produtores que vendem à consignação. têm sôbre o preço da fruta, é a constante dessas faturas que recebem dos consignatários, pois não há divulgação dos preços correntes no mercado. Êste fato coloca os produtores em posição de grande inferioridade perante seus agentes de negócios, pois têm êles que aceitar, sem. mais discussão, o preço que lhes foi faturado e que muitos produtores. acreditam não ser o verdadeiro preço de venda. Outra desvantagem dêste sistema é que poucos agentes enviam uma fatura em ordem, isto 
é, com todos os detalhes da venda, inclusive o preço bruto pelo qual foi vendida a fruta, tornando o produtor ainda mais ignorante de seus negócios. É o que se comprova com os números do quadro XIII, no qual vemos que sòmente $12 \%$ dos produtores recebem de seu consig-

\section{QUADRO XIII}

INFORMAÇŌES SÔBRE OS PREÇOS ÇONTIDOS NAS FATURAS QUE OS PRODUTORES RECEBEM QUANDO NEGOCIAM EM CONSIGNAÇAO

(Total de respostas ; 47)

Tipo de informação

$\%$ de produtores

Fatura com preço bruto e deduções detalhadas

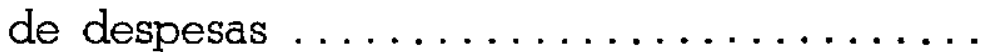

Fatura com preço líquido e sem outra informação 12,7 Fatura com preço líquido, sendo a venda controlada por parente ou sócio ............

natário uma fatura com o preço por que foi vendida a fruta e detalhes de despesas referentes à amortização do vasilhame, carretos e comissão, finalizando com o preço líquido que cabe ao produtor (ver no apêndice um modêlo dessa fatura). Quase $90 \%$ dos produtores que negociam à consignação recebem na fatura ùnicamente o preço líquido. Uma pequena percentagem de plantadores $(12,7 \%)$, apesar de só receber o preço líquido na fatura, sente-se, entretanto, bem resguardada quanto à lisura do negócio, por manter um parente ou sócio junto à banca do consignatário, controlando a venda durante tôda a safra e garantindo assim, ao produtor, o faturamento do preço realmente obtido. Este modo de operar é usado principalmente na praça do Rio de Janeiro e os produtores pagam, ao consignatário, comissões de 10 a 15\%, conforme o serviço por êle prestado: se o representante do produtor apenas fiscaliza a venda, a comissão é maior ; se, ao contrário, é o próprio representante que faz a venda, sob sua responsabilidade, a comissão é menor ; neste último caso, pode-se dizer que a comissão se torna apenas um equivalente ao aluguer da banca. Êste sistema só pode ser adotado, e de fato está assim acontecendo, pelos grandes produtores, cuja produção compensa os gastos extras que acarreta. 
preço faturado, nem sempre é o preço real de venda, pois, em geral, uma partida de frutas de um produtor é vendida em lotes de preços diversos e, segundo informações dos atacadistas, êsses enviam ao produtor um único preço na fatura e que é mais ou menos a média dos preços extremos alcançados; não há uma proporção certa para a fixação dêsse preço único, dependendo ùnicamente da vontade dos atacadistas. É claro que êste costume pode gerar muitos abusos em que os produtores serão os prejudicados.

Os atacadistas alegam que mencionam sòmente o preço líquido na fatura que enviam aos produtores devido à preferência dêstes por êsse modo de operar, o que nos parece não ser verdadeiro para a maioria dos produtores. Em geral, o atacadista nem sabe com precisão a quanto montam as despesas por unidade, apesar de possuir os elementos necessários para êste cálculo; é que, devido sua posição, não se vêm obri. gados a prestar conta dêsses detalhes; o resultado é que descontam os atacadistas dos produtores, e sem o conhecimento dêstes, quantias que imaginam compensar a despesa que tiveram no negócio, e que muitas vêzes se tornam excessivas.

A forma pela qual o consignatário de frutas calcula e cobra a comissão nem sempre é a usual no comércio e, por isso, vamos detalhá-la aqui. São duas essas formas : como uma percentagem fixa sôbre o preço de venda, ou como uma quantia variável com êsse preço. No primeiro caso, as percentagens que encontramos variavam de 7 a $12 \%$, sendo a mais comum, 10\%; quando assim calculada, a comissão pode ou não englobar as despesas que os atacadistas tiveram no negócio e, em caso positivo, a percentagem é a maior. A comissão cobrada como uma quantia variável com o preço de venda, é a forma mais usada pelos consignatários, como mostramos no quadro XIV e, neste caso, sempre engloba as despesas que os consignatários tiveram no negócio. Foi grande a variação que encontramos nas comissões calculadas por esta última forma, pois não há uma base muito real sôbre a qual os consignatários calculam êstes descontos, sendo a menor quantia cobrada aquela que, no mínimo, dá para cobrir as despesas diretas de venda, e isso só acontece quando o preço da fruta está muito baixo, ou quando o mercado está abarrotado. Em compensação, quando o preço da fruta é alto (40 cruzeiros o engradado, por exemplo), chegam a descontar metade dêsse preço como comissão (é "meio a meio" como dizem os consignatários). Essas quantias variam de um atacadista para outro e conforme o produtor, se muito conhecido, freguês antigo, etc.. Pelo que nos informaram diversos atacadistas, podemos estabelecer, em números aproximados, 


\section{QUADRO XIV \\ FORMAS DE CALCULAR E COBRAR A COMISSAO \\ (Total de respostas: 8 )}

FORMAS

$\%$ de consignatário

\begin{tabular}{|c|c|}
\hline $\begin{array}{c}\% \text { fixa sôbre o } \\
\text { preço } . . . . .\end{array}$ & $\begin{array}{l}\text { comissão engloba despesas ... } \\
\text { comissão não englob̆a despesas }\end{array}$ \\
\hline $\begin{array}{l}\text { quantia variável } \\
\text { com o preço }\end{array}$ & $\begin{array}{l}\text { comissão engloba despesas .. } \\
\text { comissão não engloba despesas }\end{array}$ \\
\hline
\end{tabular}

a seguinte proporção dos descontos mais comuns, de acôrdo com o preço da fruta :

\begin{tabular}{|c|c|}
\hline Preço de venda da fruta & Comissão èm Cr\$ \\
\hline até 8,00 & 2,00 \\
\hline de 8,00 a $10,00 \ldots$ & 3,00 \\
\hline " 10,00 a 15,00 . & 4,00 \\
\hline
\end{tabular}

Se deduzirmos dessas comissões as despesas diretas de venda feitas pelo atacadista (que detalharemos mais adiante), veremos que a comissão, pròpriamente dita, alcança, muitas vêzes, 30 e $40 \%$ do preço bruto da fruta.

Praças compradoras - As principais praças compradoras das frutas desta zona são as anotadas no quadro XV, no qual aparecem as percentagens dos produtores que negociam com cada uma delas $\left({ }^{*}\right)$. Explica-se a grande percentagem dos produtores que vendem para a cidade de São Paulo, devido à proximidade da zona produtora, relações mais fáceis com os intermediários e facilidade de transporte. Para o Rio, por exemplo, existem dificuldades quanto à duração de viagem, impossibilidade de devolução do vasilhame etc. Para o interior, a maior dificuldade é ainda o transporte. Quase $80 \%$ dos produtores inquiridos negociam em uma só praça.

(") Ver nos quadros XXIII a XXVI, as estatísticas de embarques pelas estações da Cia. Paulista de Estradas de Ferro, por praças de destino. 


\section{QUADRO XV}

NEGÓCIOS REALIZADOS COM AS PRINCIPAIS PRACGAS COMPRADORAS EM \% DE PRODUTORES

$$
\text { (Total de respostas }\left\{\begin{array}{l}
\text { Figo - 34) } \\
\text { Uva }-59)
\end{array}\right.
$$

\begin{tabular}{l|c|c|c|c}
\hline & São Paulo & $\begin{array}{c}\text { Rio de } \\
\text { Janeiro }\end{array}$ & Santos & $\begin{array}{c}\text { Interior } \\
\text { do Estado }\end{array}$ \\
\hline \hline FIGO $\ldots \ldots \ldots \ldots \ldots \ldots \ldots \ldots$ & 76,5 & 8,8 & 5,9 & 8,8 \\
UVA $\ldots \ldots \ldots \ldots \ldots \ldots \ldots \ldots \ldots$ & 72,9 & 16,9 & 5,1 & 5,1 \\
\hline
\end{tabular}

\section{DESPESAS DO PRODUTOR NA COMERCIALIZAÇÃO}

Cabe aos produtores grande parte das despesas da sua comercialização da uva e figo, não só porque a êles compete pagar carretos e fretes até a banca dos agentes, como ainda porque lhes são descontadas, felos agentes, as despesas de fornecimento de vasilhame, imposto de vendas e consignaçc̃es, fretes de vasilhame em retôrno, etc.

Essas despesas variam, não só devido à natureza de cada um dêsses itens, como também em virtude de serem calculadas de diferentes modos pelos agentes de negócios.

Por êsses motivos, precisamos dar, em detalhes, o cálculo de alguns itens, para que a despesa final seja bem compreendida; devemos esclarecer também que as quantias incluidas nos quadros finais representam as que deviam servir de base para os descontos feitos pelos agentes, mas que nem sempre são as realmente feitas.

Entre os primeiros itens de despesa estão os fretes ferroviários ; êstes variam não só com a distância como também com o número de volumes despachados, pois já vimos que os despachos menores de 48 $\mathrm{kg}$ pagam um frete fixo ( $\operatorname{Cr} \$ 2,00$ de Valinhos a São Paulo), de modo que, dentro de certos limites, quanto maior é o número de volumes em. barcados em um dia por um produtor, menor é o frete que vai pesar por unidade.

Outro ítem variável de despesa é relacionado à praça compradora, pois já dissemos que, para o Rio de Janeiro, por exemplo, além de maior frete, ocorrem certas despesas inexistentes para outras praças: perda do vasilhame e pagamento de $\operatorname{Cr} \$ 0,50$ por volume para uma pessoa fiscalizar a baldeação do Braz (S. P. R.) para Norte (E. F. C. B.) 
Finalmente, o ítem referente à amortização do vasilhame é que apresenta as maiores variações. Já vimos que, em mais ou menos $2 / 3$ de negócios destas frutas, o fornecimento de vasilhame é feito pelos agentes e poucos dêstes calculam a amortização na base de custo e duração reais; a maioria dos agentes cobra dos produtores uma quantia que imaginam suficiente para indenizar a despesa tida, e essa quantia varia de agente para agente. Por êsse motivo, vamos fazer um cálculo correto dêste ítem, baseado em elementos que nos foram fornecidos ( ${ }^{*}$ ).

A amortização do vasilhame é, naturalmente, função de seu custo e tempo de uso. O preço da caixa para uvas variou nesta safra (1942-43) de $\operatorname{Cr} \$ 2,90$ a $\operatorname{Cr} \$ 4,00$, sendo $\operatorname{Cr} \$ 3,50$ o preço mais comum para a caixa pronta. $O$ engradado para figos ficou de $\operatorname{Cr} \$ 3,50$ a $\operatorname{Cr} \$ 5,00$, sendo de $\operatorname{Cr} \$ 4,50$ o preço mais comum para o engradado pronto. Os preços mais baixos aqui apresentados se referem a atacadistas que compraram a madeira e montaram, êles próprios, as caixas e engradados, não tendo sido computado o custo do trabalho da montagem $\left({ }^{\star *}\right)$.

A duração do vasilhame, isto é, o número de viagens que êle suporta, é também um ponto sujeito à grande variação, pois, mais cedo ou mais tarde, uma certa parte se perde entre os produtores, retalhistas e consumidores. A caixa para uvas suporta até 20 viagens, ou seja mais ou menos duas salras e as perdas são pequenas. $O$ engradado para figos suporta até 15 viagens, porém as gavetas, apesar de terem uma duração física de 6 a 8 viagens, não duram mais que 2 , em média. A causa desta pequena duração é que o consumidor geralmente fica com ela ao comprar a fruta; como poucas vêzes o retalhista indeniza o atacadista no valor correspondente, êste último irá rehaver essa quantia do produtor; entretanto, êste deveria sòmente pagar uma amortização relativa ao custo e duração física de vasilhame, pois não é responsável pela sua perda nas mãos dos consumidores. Estas razões foram por nós levadas em conta no cálculo do ítem: amortização do vasilhame.

(") Os poucos ccmpradores que enviam fatura com preço bruto e deduçčes de despesas, debitaram em cada viagem, à conta de "amortização de vasilhame" - as quantias de $\operatorname{Cr} \$ 0,30$ e $\operatorname{Cr} \$ 1,50$, respectivamente, para as caixas e engradados; essas quantias representam 10 e $45 \%$ do custo.

(**) O custo do vasilhame tem aumentado bastante nestes últimos anos, concorrendo para isso a dificuldade de transporte de madeira do Paraná e o regime de quotas a que atualmente estão sujeitas as serrarias, quotas estas que parecem ser inferiores às suas capacidades de trabalho, de modo que elas se vêm obrigadas a aumen. tar os preços de seus artigos para compensar a diminuição de volume nos negócios. (As gavetas de figos, que há 2 anos custavam $\operatorname{Cr} \$ 0,30$, estão hoje a $\operatorname{Cr} \$ 0,70$ e até $\operatorname{Cr} \$ 1,00$ cada). 
Damos agora os cálculos das despesas da comercialização que, em média, devem recair sôbre os produtores, segundo a fruta negociada e a praça consumidora:

a) - Despesas do produtor na comercialização de uma caixa de uvas, de Louveira para o Rio de Janeiro:

Cr $\$$

Custo do vasilhame ............. 3,50 (*)

Papel de embalagem .............. 0,18

Frete $\ldots \ldots \ldots \ldots \ldots \ldots \ldots \ldots \ldots, 3,50{ }^{(*)}$

Fiscalização da baldeação no Braz

(S. P. R.) $\ldots \ldots \ldots \ldots \ldots \ldots \ldots, 0,50$

Carreto no Rio $\ldots \ldots \ldots \ldots \ldots \ldots, 0,40$

Cr. $\$ 8,08$

b) - Idem, idem, de uma caixa de uvas de Valinhos a São Paulo:

Cr\$

Amortização do vasilhame .......... 0,18 (")

Papel de embalagem .............. 0,18

Frete $\ldots \ldots \ldots \ldots \ldots \ldots \ldots \ldots \ldots, 0,50$

Carreto em São Paulo ........... 0,30 (***)

do vasilhame vasio em retôrno $0,10\left(^{(* \star}\right)$

Frete do vasilhame vasio em retôrno. . 0,07

Cr. $\$ 1,33$

c) - Idem, idem de um engradado de figos de Valinhos a São Paulo: $\mathrm{Cr} \$$

Amortização do vasilhame.......... 1,21

Papel de embalagem .............. 0,15

Frete $\ldots \ldots \ldots \ldots \ldots \ldots \ldots \ldots \ldots, 0,50{ }^{(*)}$

Carreto em São Paulo ........... 0,30 (***)

do vasilhame vasio em retôrno $0,10\left(^{(* *}\right)$

Frete do vasilhame vasio em retôrno. . 0,07

Cr. $\$ 2,33$

(*) Preço base do vasilhame: Caixa $\operatorname{Cr} \$ 3,50$; engradado $=\operatorname{Cr} \$ 4,50$.

Duração do vasilhame: Caixa $=20$ viagens; engradado $=15$ viagens ; gaveta $=2$ viagens.

("*) Fretes calculados para despachos de $60 \mathrm{~kg}$ de frutas.

(*+*) Carretos com agências e carregadores tratados para todos os transportes da banca, durante 0 ano. 


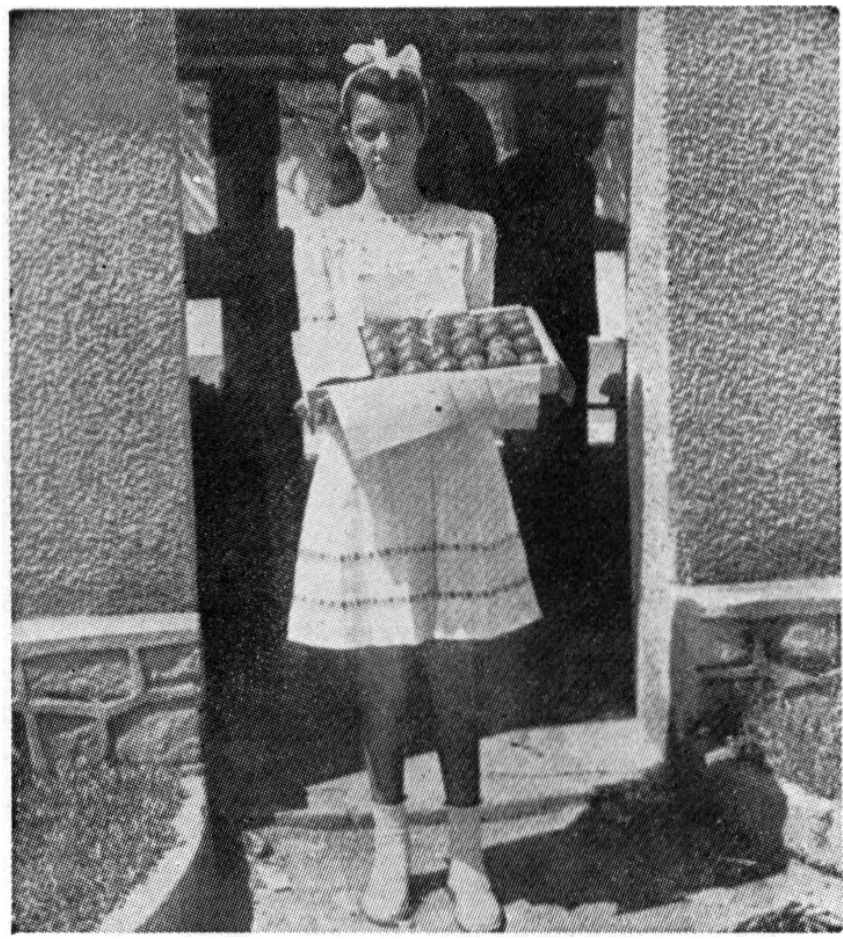

Fig. 5 -... A classificação e embalagern são, em geral, cuidadosas e a apresentação final é boa. Esta gaveta de tigos é classificada como de l." qualidade. (Foto Paulo Cuba)

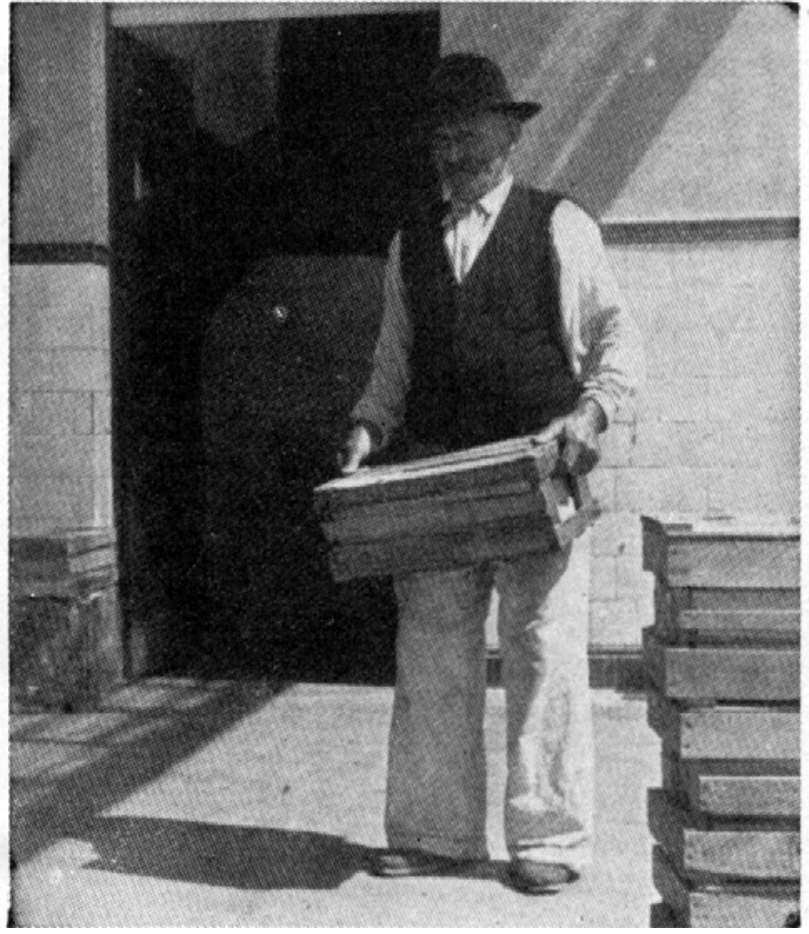

Fig. 6 -- $O$ engradado de figos possui 3 gavetas e pesa, em média, $9 \mathrm{Kg}$. (Foto Paulo Cuba)

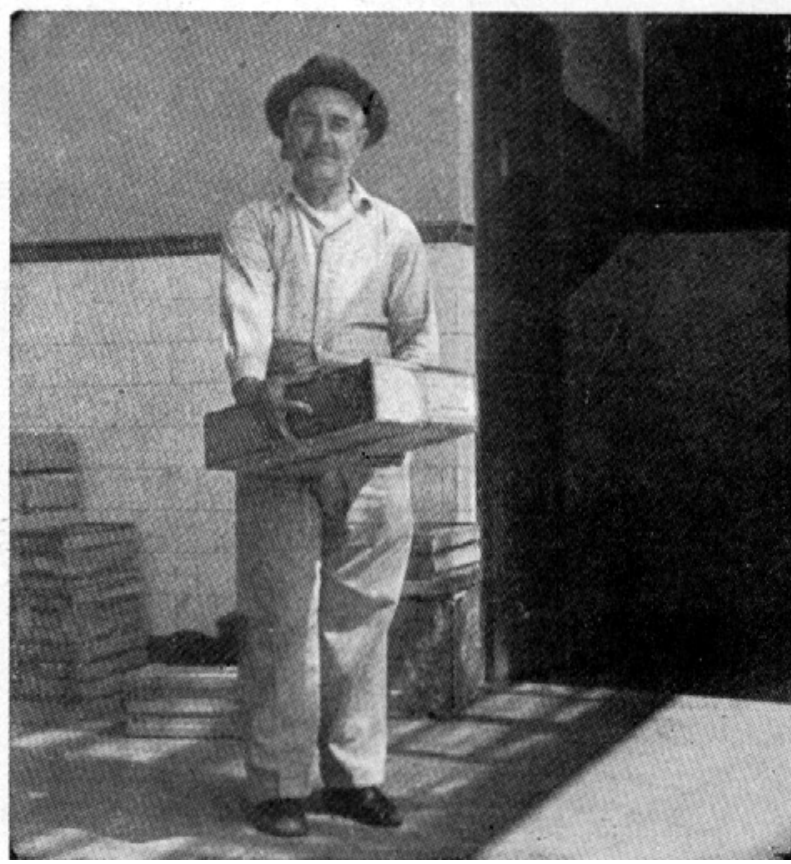

Fig. 7 ... A caixa de uvas é de modêlo padrão e pesa 10 a $11 \mathrm{Kg}$. (Foto Paulo Cuba) 


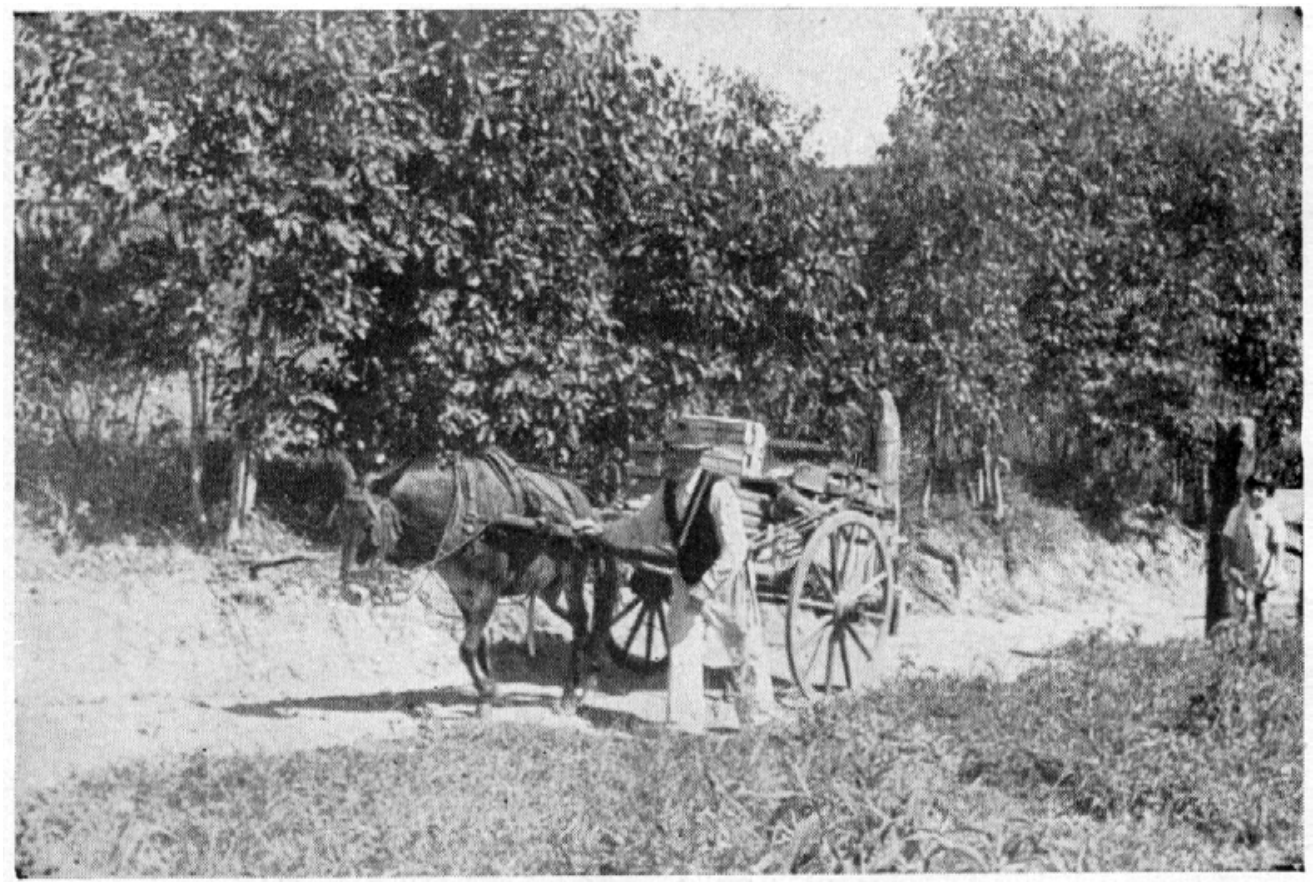

Fig. 8 - Sitiante e sua carrocinha a caminho da estação para o despacho diário. (Foto Paulo Cuba)

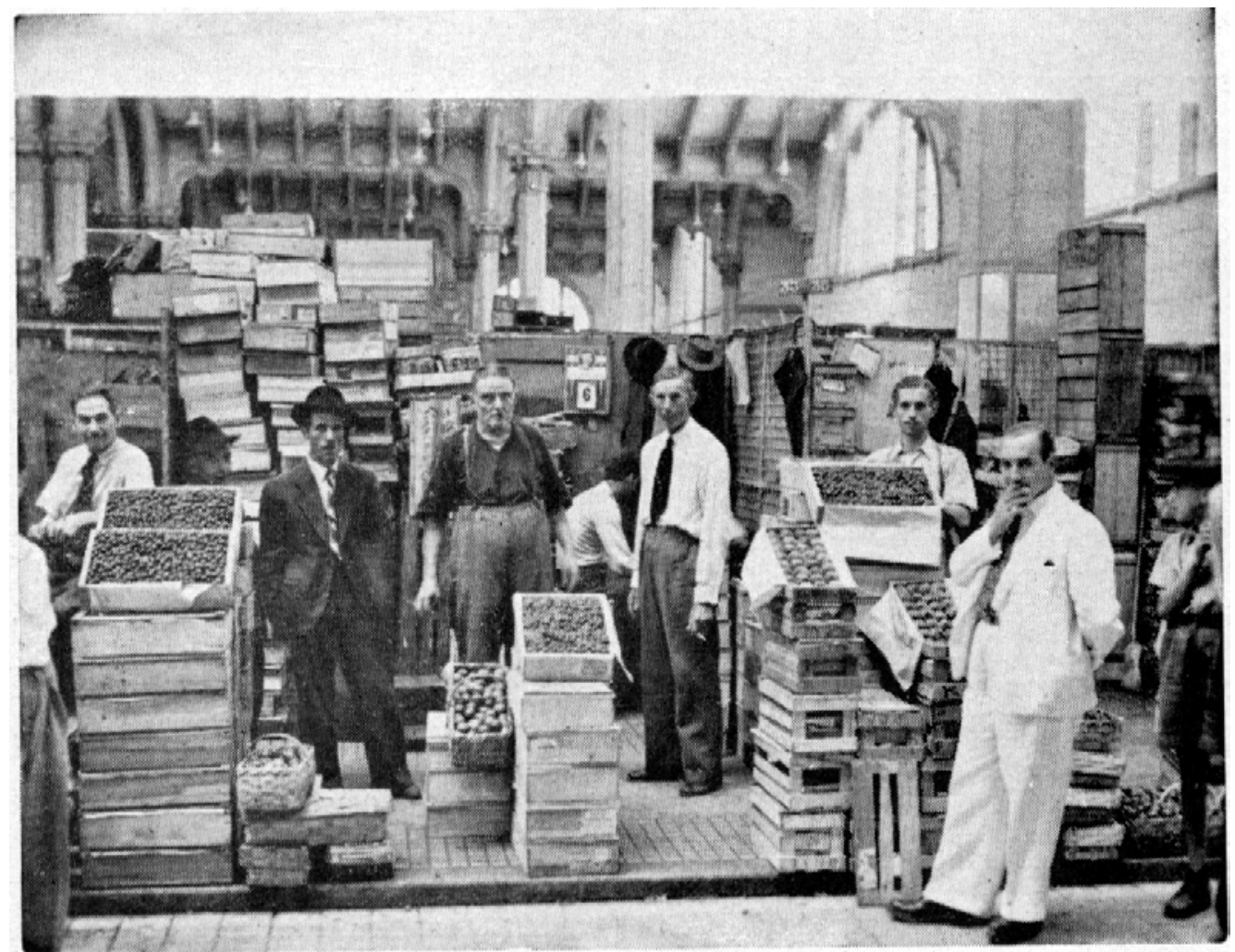

Fig. 9 -.. A banca de um atacedista no mercado municipal de S. Paulo. De cada tote de frutris sian abertos um on dois volumes para verificação da qualidade. (Fontı $G$. Comparini) 
Não foram computados, nestas despesas, mais os ítens adiante enumerados, pelos seguintes motivos : 1) carreto dos sítios às estações de embarque, geralmente feito pelos próprios produtores e para o qual não há base de cálculo; 2) imposto de vendas e consignações $(1,40 \%$ sôbre o valor da venda) que o agente cobra do produtor, e comissão do agente - que por serem quantias variáveis com o preço da fruta, não puderam ser incluídas aqui.

\section{COOPERATIVA DE VENDA}

Muitas queixas que os produtores têm do comércio poderiam ser sanadas se êles se reunissem em cooperativas de venda que executariam alguns dos serviços prestados pelos intermediários. Essa solução foi tentada em 1940 por alguns plantadores de uva de Louveira, que se reuniram em uma Cooperativa, cujo fim principal era a venda de sua fruta $\left(^{*}\right)$. A Cooperativa esteve em atividade desde aquela data até a safra de 1943-44, qundo os cooperados resolveram suspender, por um ano, sua operação, isto é, só recomeçar a trabalhar na safra de 1944/45. O motivo determinante desta atitude parece ter sido o pequeno número de produtores - 5 apenas - que negociaram por intermédio da Cooperativa durante tôda esta safra, e isso num total de 53 cooperados cotistas.

A Cooperativa funcionava como um agente de vendas, pois tinha representantes em São Paulo e Rio de Janeiro; êstes, alugavam bancas no Mercado mediante uma comissão de 10 a $15 \%$ paga ao "barraqueiro". Estes representantes telefonavam diàriamente à sede da Cooperativa em Louveira, comunicando as condições de cada um dêsses mercados; dêsse modo, os produtores consignavam sua fruta para o representante da Cooperativa, na praça que mais lhes conviesse no momento. Após a venda, o representante enviava ao produtor uma fatura com o preço bruto alcançado por sua fruta e, na sede da Cooperativa, eram descontadas comissões de 10 ou $15 \%$ e mais uma taxa de $\operatorname{Cr} \$ 0,50$ por volume, que entrava para o fundo de reserva da Cooperativa, uma vez deduzidas as despesas de venda. Além dêsse serviço, a Cooperativa vendia a preço de custo, aos seus associados, o vasilhame $e$ inseticidas de que êstes necessitassem.

(") Em Valinhos também já foi fundada uma cooperativa de produtores de figo, de pequena duração, porém. Cabe mencionar aqui, ainda, que alguns associados da Cooperativa Agrícola de Cotia, são plantadores de figo e uva e negociam estas frutas, por intermédio de sua Cooperativa. Entretanto, é pequena sua produção total. 
Não fizemos, e não caberia mesmo aqui, um estudo detalhado a respeito dos negócios desta Cooperativa, de modo que não podemos precisar os motivos porque a maioria dos cooperados não se utilizou da associação, na venda de suas frutas. Entretanto, queremos divulgar aqui alguns fatos que tivemos ocasião de observar em nossas visitas aos produtores os quais mostram, a nosso ver, algumas causas dos insucessos de certas cooperativas de produtores entre nós.

Em primeiro lugar, é necessário acentuar que o posso agricultor vive em grande isolamento, tanto físico como espiritual, o que é motivo para nêle se desenvolver um grande espírito individualista, tornando-o pouco interessado em um movimento cooperativista. Por êsse motivo, acreditamos que as cooperativas, para vencerem, precisam oferecer uma grande soma de vantagens aos agricultores, sem o que êstes preferirão continuar a agir sòzinhos.

Para mostrar que êstes agricultores não estão ainda identificados com o verdadeiro espírito cooperativista, basta citar o seguinte fato que tivemos ocasião de presenciar: bastava um produtor cooperado saber que um vizinho não cooperado obtivera, naquele dia, um preço melhor que o da Cooperativa, para ficar de prevenção e, na primeira oportunidade em que tal se repetisse, deixar de enviar sua fruta para a Cooperativa, consignando-a a um atacadista do Mercado, sem procurar esclarecimentos, com outros cooperádos, sôbre as causas daquele fato e modo de remediá-lo.

Outro fato significativo, também por nós presenciado, é que muitos prcdutores não concordam que as cooperativas paguem de 600 a 800 cruzeiros mensais ao seu gerente, pois acham que são quantias excessivas. Não compreendem êles que essa pessoa precisa ser bem qualificada, um perito nesse ramo de negócios e, portanto, deve ser remunerada de acôrdo com seu serviço. Êste caso sem importância na aparência, é restritivo à adesão de muitos produtores à Cooperativa.

Para caraterizar melhor como é encarada, por êstes lavradores, a questão das cooperativas, queremos citar o círculo vicioso em que ela cai, conforme tivemos ocasião de constatar: quando interrogávamos pequenos produtores, porque não entravam para a Cooperativa, respondiam citando que fulano ou sicrano, grandes plantadores, não haviam entrado, de modo que êles também não se sentiam seguros em fazer karte. Quando, por sua vez, interrogávamos os grandes plantadores, êstes alegavam, com razão, que colocavam fàcilmente sua fruta, e, alguns, por sua própria conta, de modo que não tinham queixas do negócio e não se interessavam por cooperativas. 
Além da falta de espírito cooperativista, outros fatos concorrem para acentuar mais a frieza dos produtores ante êste movimento. É o caso, por exemplo, das vantagens de que, por lei, gozam as cooperativas; na prática, entretanto, qualquer cooperativa esbarra numa porção de embaraços que legalmente não deveria encontrar; podemos citar o fato de as cooperativas funcionarem sob isenção de impostos mercantis e, no entanto, muitas delas são taxadas pelas repartições arrecadadoras, como se fôssem casas comerciais, e são obrigadas ou a gastar dinheiro ou a perder tempo em demandas, a fim de fazer valer seus direitos, sem que possam chegar, muitas vêzes, a uma solução satisfatória. Outro ponto, é o relativo ao crédito agrícola, que deveria ser de mais fácil obtenção por meio das cooperativas; estas, entretanto, têm muita dificuldade em obtê-lo nos bancos oficiais. Disso resulta, como no caso dêstes produtores de figo e uva, que sejam êles obrigados a tomar dinheiro emprestado aos agentes de negócios, ficando, assim, na dependência econômica dêstes.

Além destas dificuldades, outras mais se apresentam às cooperativas de venda de produtos, como figos e uvas, e de cuja resolução depende o bom êxito do negócio. Entre essas dificuldades, está a da escolha do agente de vendas no Mercado: êsse agente, não só deve ser conhecedor da parte agrícola, como deve possuir bastante prática comercial, pois a cooperativa irá concorrer com negociantes veteranos, conhecedores de pequenos detalhes e "manhas" próprias dêste comércio; ora, a tendência geral é colocar um cooperado neste cargo o que, na maioria dos casos, concorre para o fracasso da cooperativa, pois êste agente, não tendo prática do comércio, será fàcilmente sobrepujado na concorrência com os atacadistas do Mercado.

Outra desvantagem da Cooperativa é que ela só entra no mercado na época da safra de figo e uva, ao contrário dos atacadistas, que negociam com diversos produtos durante o ano todo e criam, dêsse modo, uma freguesia certa para muitos produtos. Êstes compradores só abandonarão seus atacadistas habituais se a Cooperativa puder oferecer boas vantagens quanto a preço e qualidade. A Cooperativa poderia vender seus produtos por um preço menor que os atacadistas, baseada em um menor custo de operação; acreditamos, entretanto, que essa diferença ainda é pequena para provocar o deslocamento de frequesia, o que só se daria se a Cooperativa também apresentasse vantagens quanto à 
qualidade, isto é, se apresentasse ume produto padronizado. É, aliás, o que tem feito a Cooperativa de Cotia com a produção de tomate de seus associados, tôda ela rigorosamente classificada, obtendo preços melhores que a de qualquer outra procedência.

\section{COMERCIALIZAÇÃO PELOS ATACADISTAS}

\section{Caraterísticos do comércio atacadista}

Como já dissemos, os atacadistas de figos e uvas se acham localizados quase exclusivamente no Mercado Municipal de São Paulo, onde alugam "bancas" para depósito e venda de frutas. Para a instalação dos negociantes que aí se estabelecem, o Mercado Municipal está todo dividido em compartimentos, comumente chamados "bancas" ou "barracas", separadas entre si por telas metálicas de 2 metros de altura. A área destinada ao comércio de frutas e hortaliças está situada na parte sul do edifício, entre as ruas internas $\mathbf{H}$ e $\mathbf{O}$. $O$ tamanho das bancas varia com o tipo de produto negociado; as bancas típicas dos atacadistas de frutas têm, na generalidade, as dimensões de 3,50 × 3,20 metros. $O$ atacadista pode alugar mais de uma banca, segundo as exigências de seu volume de negócios, sendo grande o número dos que alugam duas bancas, geralmente contíguas. Atualmente, é difícil conseguir uma banca, motivo por que alguns atacadistas se vêem impossibilitados de aumentar seu volume de negócios.

Os atacadistas geralmente se especializam no comércio de sòmente uma ou duas de nossas frutas de produção comercial, ou, então, importadas; assim, encontram-se alguns atacadistas que são especializados no comércio de laranjas, outros, no de figos e uvas ; outros, no de pêras e maçãs estrangeiras, etc. Entretanto, além dêsses produtos que formam a base de seus negócios, os atacadistas ainda negociam com outras frutas (abacate, abacaxi, mamão, manga, caqui, etc.) algumas hortaliças (tomate, pepino, alcachofra, etc.) e, raramente, ovos. Esstes produtos, porém, são quase sempre negociados em pequeno volume, formando a parte subsidiária do negbcio, pois sua produção (com exceção da de tomate), é esparsa e intermitente, isto é, produção de tipo não comercial, não comportando, pois, organizações especializadas. Em virtude disso, quando termina a safra dos produtos básicos do negócio - de figo e uva, por exemplo - diminui bastante o volume de negócios dêsses atacadistas. 
A inclusão de outras frutas e algumas hortaliças no negócio dos atacadistas, durante a época de venda dos seus produtos básicos, torna-se uma necessidade neste comércio, por dois motivos: $1^{\circ}{ }^{\circ}$ - assim procedendo, o atacadista diminui o custo de operação; $2 .{ }^{\circ}$ ) - porque, assim, êle poderá servir aos compradores com uma série de artigos durante todo o ano, formando, então, uma freguesia certa e evitando que seu comércio sofra solução de continuidade.

O número de atacadistas que negociam com figo e uva é variável, de ano para ano. Nesta safra, eram mais ou menos 15 os atacadistas que tinham, nestas duas frutas, a base de seus negócios; além dêsses, mais uns 10 também negociaram com figo e uva, sendo, porém, estas frutas sòmente a parte subsidiária de seu comércio.

\section{VEND A}

$O$ atacadista vende a fruta às seguintes classes de retalhistas: feirantes, fruteiros, ambulantes, quitandeiros, hotéis e restaurantes ; ocasionalmente, vende diretamente a consumidores e, algumas vêzes, a representantes locais de atacadistas do Rio de Janeiro.

Não nos foi possível obter dados sôbre as quantidades escoadas através de cada uma dessas classes de retalhistas; entretanto, pela ordem em que foram colocadas, podemos considerar como decrescente com relação ao volume de negócios de cada uma.

Hora da venda - $\mathrm{O}$ atacadista recebe diàriamente, em sua banca, fruta enviada por diversos produtores; o período mais comum em que essa mercadoria chega às bancas, é o da manhã ; entretanto, devido à atual irregularidade nos transportes ferroviários, a chegada pode ocorrer a qualquer hora do dia, havendo mesmo dias em que não há descarregamento de frutas. Em virtude da variação na hora da chegada, a venda também se processa durante todo o dia, obrigando o atacadista permanecer na banca das 6,00 às 18,00 horas.

De um modo geral, cada classe de retalhista tem preferência por um certo período do dia para fazer suas compras. Assim, os feirantes, geralmente, compram à tarde a mercadoria que irão revender no dia seguinte. Já os ambulantes de frutas preferem fazer suas compras bem cedo, pela manhã, a fim de lhes sobrar tempo para visitar a freguesia até mais ou menos o meio do dia, que é o período de maior venda. As frutarias, hotéis e restaurantes também dão preferência ao período da manhã para suas compras. Ùltimamente, devido às irregularidades de transporte, êsses hơórios não têm sido estritamente observados pelos compradores. 
Unidade de venda - Apesar de, por lei, ser denominado retalhista e, portanto, estar sujeito às normas dêsse comércio, o atacadista não se interessa e nem é solicitado, na prática, a vender a retalho, pois, existindo no próprio Mercado muitos retalhistas é a êstes últimos que se dirigem os que querem comprar pequenas quantidades de frutas. Dêsse modo, as menores unidades em que os atacadistas vendem a uva e o figo, são caixas e engradados, ịsto é, na embalagem em que recebem essas frutas dos produtores.

Como vendem - Uma vez chegada a fruta na banca, o atacadista separa os volumes em lotes de tipos diferentes e abre um ou dois volumes de cada lote que são, assim, deixados em exposição aos compradores. Geralmente, os retalhistas vêm, diàriamente, ou de 2 em 2 dias, ao Mercado, a fim de comprar frutas; gostam de, êles próprios, inspecionar a mercadoria. Os interessados em maiores partidas, à vista da fruta exposta, fazem suas compras sem abrir os demais volumes e, dêsse modo, a fruta vai ao comércio retalhista na embalagem original dos produtores. Os pequenos retalhistas, entretanto, gostam de abrir todos os volumes que pretendem comprar, no que os atacadistas não fazem objeção.

Encontramos sc̀mente um atacadista fazendo a venda de um modo diferente : for já ter um certo número de fregueses regulares, da estação de desembarque êle já sai com um caminhão carregado de frutas e as vai distribuindo na cidade e nos bairros; sòmente a fruta que não foi colocada entre êsses fregueses é que o atacadista leva para sua banca no Mercado, para venda a compradores eventuais.

São em pequeno número os retalhistas que fazem compras pelo telefone; só usam êste meio, aquêles que são afreguesados com um único atacádista, e, assim, êste já sabe o tipo de fruta que o freguês deseja ; em geral, hotéis e restaurantes são fregueses que compram dêste modo.

O atacadista vende geralmente a dinheiro, mas também faz algum fiado a fregueses conhecidos; neste último caso, o prazo de pagamento é de alguns dias ou uma semana. Não pudemos obter a percentagem de negócios feitos a crédito, mas todos os atacadistas, por nós inquiridos, haviam sofrido prejuizos com êste sistema de negócio, podendo-se calcular êsse prejuizo em $5 \%$ sôbre o volume total negociado.

O atacadista não se encarrega do carreto da fruta, a não ser nas compras por telefone, mas, em qualquer caso, o carreto é sempre pago pelo comprador. Este carreto é feito geralmente por carregadores com 
ponto no Mercado, sendo usado, no transporte de poucos volumes a pequenas distâncias, um tipo de carrinho de mão e para maiores quantidades e distâncias longas, carroça e caminhão.

Risco - O risco que o atacadista corre varia com seu sistema de negócio. Quando o atacadista negocia à consignação, o risco é menor, pois a qualquer prejuizo que ocorra, o maior dano recai sôbre o produtor consignante, que é o dono da fruta; nesse caso, o atacadista ùnicamente tem diminuído o seu lucro. $O$ maior risco é o de encalhe da mercadoria, mas êste também é pequeno, pois a maioria da fruta é vendida no mesmo dia da chegada. Pelo que nos informaram os atacadistas, podemos afirmar que $90 \%$ da uva e $80 \%$ do figo são vendidos no mesmo dia em que chegam ao Mercado. Não foi possível determinar as quantidades de figo e uva perdidas por encalhe ou por chegarem as frutas estragadas ; entretanto, pelas informações que nos foram dadas, verificamos que o máximo atingido foi de $5 \%$ do total recebido; em média, essa quantidade é de 2-3\%. Assim mesmo, o prejuizo só é completo quando as frutas chegam esmagadas, devido à falta de cuidado nas estradas de ferro, pois a uva "passada", imprópria para consumo, é geralmente vendida para fábrica de vinagre e, mesmo, de vinho ( ${ }^{*}$ ); o figo "passado" já é mais difícil de colocar, mas, como dizem os atacadistas, "tôda fruta encontra comprador" e, neste caso, êle é, em geral, o ambulante modesto, que só pode pagar um preço menor que o vigente para a fruta boa.

Já o atacadista que negocia a "preço fixado" corre maior risco, porque a qualquer preço de mercado igual ou inferior ao preço de compra, êle está perdendo dinheiro; e, apesar de pouco numerosas, situações como esta têm causado grandes prejuizos a alguns atacadistas. E é êste um dos motivos por que não é maior o número de atacadistas dispostos a negociar por êste sistema.

Informações de mercado - Certas informações de mercado seriam de grande utilidade aos atacadistas de figo e uva, pois possibilitariam que trabalhassem com maior segurança ; tais seriam, por exemplo, estimativas de safra, feitas de tempos a tempos; estatísticas de embarques para as diversas praças ; estudos sôbre as tendếncias da procura, etc. Como não existem essas informações, os negociantes são obrigados, ao fazerem seus negócios, a se valerem ùnicamente da experiência obtida nos anos anteriores o que, muitas vêzes, é insuficiente e conduz

(*) Essas fábricas chegaram a pagar, em 1943-44, Cr\$15,00 por caixa, para fruta em qualquer estado. 
a enganos que se traduzem em prejuizos, os quais sòmente poderão concorrer para a instabilidade dêsse comércio.

A única informação de mercado, que é mais ou menos sistemàticamente utilizada, é a estatística dos desembarques diários de figo e uva em São Paulo que, como veremos, tem grande influência na determinação do preço do dia. Não que exista uma estatística especialmente levantada para êsse fim; mas os atacadistas se valem dos motoristas da agência que se encarrega do transporte das frutas, para conhecerem, aproximadamente, a quantidade chegada; essa agência de transportes faz o serviço para quase todos os atacadistas, de modo que, ao realizarem os primeiros carretos, os motoristas informam aos negociantes sôbre o número e tipo dos vagões chegados e carregados com frutas. Conhecendo essa quantidade, os atacadistas ficam com melhor base para julgarem as condições do mercado naquele dia e seus prováveis reflexos sôbre os preços.

\section{DESPESAS DOS ATACADISTAS}

Já vimos que são diversas as despesas diretas que os atacadistas têm no comércio de figo e uva, mas, de quase tôdas, êles são posteriormente reembolsados, direta ou indiretamente pelos produtores. A única exceção é a despesa com o imposto de vendas e consignações. Já vimos que êste imposto é pago duas vêzes pelos atacadistas: a 1.a quando recebe a fruta do produtor, pois são obrigados a registar a transação em seu livro de compras; e a 2. ", quando vendem a fruta e fazem o registo no livro de vendas à vista. $O$ imposto de compra o atacadista desconta do produtor, como já dissemos; resta, pois, como despesa direta do negócio, ùnicamente 0 imposto cobrado pela venda da fruta.

Além dessa, o atacadista tem outras despesas que podemos chamar de fixas, pois onera o negócio quase que independente do volume de vendas e do número de artigos negociados. Não nos foi possível calcular exatamente a percentagem destas despesas que recaem sôbre uvas e figos, xorque elas incidem globadamente sôbre todos os artigos vendidos pelos atacadistas e seria necessário um exame minucioso em seus livros comerciais para se poder fazer êsse cálculo e isso não foi possível. Entretanto, em outro capítulo, quando tratarmos das margens e lucros dos intermediários, usaremos os dados que aqui apresentamos numa tentativa para determinar a despesa do atacadista por unidade de venda de figo e uva. 
Vamos relacionar, em seguida, a quantia anual referente a essas despesas fixas, dispendida por um atacadista que pode ser considerado como típico da classe.

\section{QUADRO XVI}

DISCRIMINAÇAO DAS DESPESAS FIXAS DOS ATACADISTAS
Í T E N S
DESPESAS

Aluguer da banca no Mercado (a) ..........

Cr\$2.310,00

Salário de um empregado (b)

$4.320,00$

Impostos :

Sindical. ...................

20,00

Indústrias e Profissões . . . . . . . . . . 1.200,00

Renda . . . . . . . . . . . . . . . . . 150,00

Guerra ..................... 150,00 1.520,00

Taxas

Alimentação Pública ... . . . . . . . . . 100,00

Instituto de Aposentadorias . . . . . . . 324,00 424,00

Escrituração Comercial .............. 180,00

Total. . . . Cr $\$ 8.754,00$

(a) A Prefeitura de São Paulo cobra Cr\$ 17,50 mensais, por metro quadrado, sendo de $11 \mathrm{~m}_{2}$ a área de uma banca comum.

(b) À base do salário mínimo estatuído pelo Decreto Federal n.* 5.919 de 1944.

Não estamos computando nesse quadro as despesas com telefone (que nem todos atacadistas possuem) e as com rótulos e faturas que são enviadas aos produtores.

\section{COMERCIALIZAÇÃO PELOS RETALHISTAS}

\section{Caraterísticos do comércio retalhista}

A principal função do comércio retalhista é colocar a mercadoria à disposição dos consumidores nos lugares apropriados, em tempo oportuno e nas quantidades e qualidades desejadas. Pela execução desta função (que, de certo modo, pode ser considerada como a de um agente de compra dos consumidores) é que as atividades dos retalhistas são geralmente analisadas, pois são as que interessam à maior parte da população. 
Para executar a contento essa função, o retalhista precisa desenvolver uma atividade múltipla, pois diversos serviços precisam ser desempenhados. Em maior ou menor grau o retalhista executa todos os serviços da comercialização, tais como os de reunião, venda, transporte, armazenamento, responsabilidade de risco, classificação e financiamento. Principalmente quanto ao modo como é executado um dos principais serviços - a venda — os retalhistas podem ser grupados em classes distintas.

$\mathrm{Na}$ cidade de São Paulo podemos grupar os retalhistas de frutas, em geral, em 5 classes; Feirantes, Fruteiros, Ambulantes, Quitandeiros e Hotéis e Restaurantes. Cada uma dessas classes de retalhistas apresenta caraterísticos próprios, que passaremos a descrever de modo rápido.

Feirantes - Esta é uma classe importante no comério retalhista de figos e uvas, pois, provàvelmente, é a que vende maior quantidade dessas frutas; além disso, por se localizar nos mais diversos bairros da cidade, o comércio das feiras serve a um grande número de consumidores e das mais diversas classes sociais.

Os feirantes formam uma classe bem uniforme, pois não só usam as mesmas normas de comércio, como ainda têm poucas possibilidades de diferençar seu "estabelecimento" do de seus colegas (") ; também contribui para essa uniformidade, o fato de se distribuirem êles durante a semana entre as diversas feiras da cidade, isto é, entre as boas e más, as dos bairros ricos e pobres, etc.

No ano de 1943 existiam 256 feirantes licenciados pela Prefeitura(**) para a venda de frutas nacionais e estrangeiras nas 36 feiras semanais do Município da Capital $\left(^{* * *}\right)$. Ao obter a licença, cada feirante se inscreve em uma das feiras diárias, podendo haver transferências, a juizo da Prefeitura. O número médio de feirantes de frutas é de 30, em cada feira.

A banca do feirante é a mais simples possível, constando de cavaletes sôbre os quais são colocadas algumas tábuas e onde fica exposta

(*) Com exceção da localização, que é um grande elemento diferençador, como veremos logo mais.

(**) Informação da Secção de Feiras Livres da Prefeitura Municipal de São Paulo.

(***) São os seguintes os bairros ou locais, em que se realizam feiras livres: largo Guanabara, Av. Tiradentes (duas), Vila Pompéia, Pinheiros, Cambucí, Áv. Angélica, Freguesia do O', Morais Barros, Praça Almeida Jr., Largo do Arouche (duas), Mobca, Barra Funda, Casa Verde, Belém, Jardim América, São Caetano, Piratininga, Perdizes, Bexiga, Santo André, José Maria Lisboa, Sant'Ana, Aclimação, Pari, São Bernardo, Lapa, Penha, Vila Carrão, Vila Prudente, Indianópolis, Bosque da Saude, Ipiranga, Tucuruvi, Jabaquara. 
a mercadoria; na sua maioria, as bancas possuem um tôldo de cobertura para proteção das intempéries.

Estes feirantes vendem exclusivamente frutas, das mais variadas espécies, conforme a época do ano. Alguns são mais especializados, pois só vendem bananas, por exemplo, ou, então, só pêras e maçãs (estas são frutas encontradas no mercado em qualquer época) ; entretanto, na época de figo e uva, estas duas são, com exceção da banana, as frutas mais encontradas em quase tôdas as bancas das feiras.

A fruta vendida pelos feirantes, em geral, é de 1.a qualidade, mas êles sempre têm algumas caixas e engradados com fruta de $2 .{ }^{a}$ e com a qual atendem os fregueses menos abastados, ou a venda de frutas avulsas ou cachos para consumo imediato, que é bastante generalizado nas feiras. Muitas vêzes, essa fruta de pior qualidade é o "encalhe" do dia anterior.

Fruteiros - Esta é outra importante classe de retalhistas de figos e uvas, tendo um volume de vendas que, provàvelmente, iguala ao dos feirantes. Os fruteiros diferem bastante entre si, quanto ao tipo do estabelecimento, localização, espécie de fregueses servidos, volume de vendas, etc., motivo por que não constituem uma classe uniforme como a dos feirantes ( ${ }^{*}$ ).

Os estabelecimentos que vendem exclusivamente frutas, são em pequeno número e se localizam, de preferência, no centro da cidade. $O$ tipo mais comum de frutaria são as bancas situadas nas portas dos cafés, bares, mercearias, etc., existentes em grande número, tanto no centro da cidade como nos bairros. Estas bancas são muito simples, em geral constituídas de um balcão com prateleiras, onde são colocadas as frutas; o arranjamento do estande de frutas é feito com maior ou menor capricho conforme o tipo do estabelecimento; uns procuram dispô-las de modo a despertar a atenção dos fregueses e outros expõem simplesmente a fruta na própria embalagem original.

Com relação aos artigos vendidos, encontram-se desde frutarias que vendem sòmente algumas frutas nacionais, como bananas e laranjas, até as que negociam diversos artigos: frutas nacionais e estrangeiras,

(*) Segundo informações prestadas pela Diretoria da Receita da Secretaria da Fazenda e baseadas no pagamento do imposto de Indústrias e Profissz̃es, existiam 1.281 estabelecimentos licenciados para a venda de frutas e hortaliças na cidade de São Paulo, no ano de 1943. O número acima engloba tanto as frutarias como as quitandas, pois, para efeito de pagamento dêsse imposto, não há separação entre essas duas classes de retalhistas; por ésse motivo, não nos foi possível verificar o número de frutarias, exclusivamente. 
queijos, doces enlatados e em pacotes, conservas, balas etc. ; geralmente as frutarias dos bairros se assemelham ao tipo mais simples des. crito, ao passo que as do centro da cidade são as que apresentam maior variedade de produtos. As frutarias também variam relativamente à direção do negócio: assim, algumas, apesar de se localizarem na porta de um café ou bar, podem não ter nenhuma ligação com êsses outros negócios, sendo o espaço alugado ao fruteiro que dirige independentemente seu estabelecimento; outras frutarias são parte de um negócio que compreende bar, café, charutaria, tudo de um só proprietário, que coloca em cada uma dessas seç̧ões um gerente "interessado", que a dirige com certa independência. Outra modalidade de frutarias que se está desenvolvendo ùltimamente é a venda nas mercearias, constituindo uma secção nos negócios desta e sob a direção do proprietário ou do gerente geral.

A qualidade da fruta vendida por êstes retalhistas é bastante variável, pois, enquanto as frutarias do centro da cidade em geral apresentam à venda fruta de 1.a qualidade, já nos bairros, o mais comum, é a frutaria modesta que expõe à venda fruta mais barata, de $2 .^{a}$ ou pior, porque, geralmente, seus fregueses são pessoas de menores posses.

Ambulantes - Esta classe de retalhistas, colocada em 3.0 lugar em volume de vendas de figo e uva, apresenta-se de grande interêsse, pois é a que, por seu sistema de negócio, està adaptada para, mais fàcilmente que qualquer outra, servir ao consumidor. $\bigcirc$ volume relativamente pequeno de negócios dêstes retalhistas com figos e uvas é um dos sinais mais evidentes do pequeno consumo dessas frutas entre as classes menos afortunadas da população, pois são êstes ambulantes que, em grande parte, as suprem diàriamente com frutas e hortaliças.

Os ambulantes não formam uma classe uniforme de retalhistas, podendo-se separá-los em diversos tipos, segundo seu modo de venda. O mais comum é o ambulante que possui uma carrocinha puxada a animal e com a qual corre diàriamente (em geral pela manhã) a freguesia do seu bairro, vendendo as frutas da época; até pouco tempo, figos e uvas eram frutas que raramente se encontravam nestes retalhistas, mas hoje já fazem parte do negócio de grande número dêles. Outro tipo de ambulante é o que possui uma carrocinha de mão e estaciona durante todo o dia, habitualmente nos mesmos lugares, em pontos de grande movimento, como sejam : junto ao portão das fábricas, nas esquinas ou praças centrais, etc.. Na época de figo e uva, essas duas frutas são as mais vendidas por êsses ambulantes. Após o decreto que isentou 
os ambulantes de frutas dos impostos e taxas estaduais, tem aparecido com maior frequência, que antes, um outro tipo de ambulante : é aquêle que, com um caminhão ou carrocinha de tração animal, percorre em certos dias (principalmente aos sabados e domingos) ora um, ora outro bairro da capital, vendendo as frutas de maior produção no momento (laranjas, figos, uvas, abacaxi, etc.). Finalmente, outro tipo de ambulante, o mais modesto e menos comum, é o que estaciona em algum ponto movimentado da cidade com uma ou duas cestas de frutas, geralmente pêras e maçãs $e$, no tempo de figo e uva, também com essas duas frutas ; a venda de figo e uva por êstes retalhistas é bem pequena. Devemos incluir também na classe de ambulantes, os chamados verdureiros, que vão diàriamente de porta em porta da freguesia de seu bairro, vendendo principalmente hortaliças e algumas frutas; ainda que a venda de figo e uva por êstes ambulantes seja pequena, pois, em geral, só as frutas mais comuns (banana e laranja) é que são oferecidas, muitos verdureiros já introduziram essas duas frutas em seu negócio e as oferecem, principalmente, em certos dias, como os sabados e domingos.

Em 1943 existiam 561 ambulantes de frutas na cidade de São Paulo, incluindo todos os tipos atrás descritos (*).

Com relação à qualidade da fruta vendida por êstes retalhistas já dissemos, em outro lugar, que ela é em geral de 2. a, não só porque os consumidores por êles servidos são das classes menos abastecidas, como também devido ao sistema de negócio usado, que é o retalho nas menores quantidades possíveis, prática usada principalmente por certos tipos de ambulantes que vendem o figo em unidades e a uva em cachos.

Quitandeiros - Nesta classe incluimos os pequenos estabelecimentos situados principalmente nos bairros e que vendem hortaliças e frutas, além de alguns outros poucos artigos, como fósforos, doces baratos, pão, salame, etc. $\left(^{* *}\right)$. Êsses estabelecimentos geralmente estão situados em pequenas salas, e a mercadoria é exposta sem nenhum arranjamento especial, em balcões simples, prateleiras, caixões, etc. A importância dêstes retalhistas é pequena na venda de figos e uvas, pois, em geral, só vendem as frutas mais comuns e baratas, como banana,

(') Informações prestadas pela Diretoria da Receita da Secretaria da Fazenda, com base no pagamento do imposto de Indústrias e Profissões. Em 2-3-1944, os ambuJantes foram isentados dêsse imposto pelo Decreto n. ${ }^{\circ} 13.859$ da Interventoria Federal.

(**) Ver nota (*) na página 483. 
laranja, mamão, etc. ; figo e uva só são encontrados nas quitandas dos melhores bairros residenciais. De um modo geral, a fruta vendida nas quitandas é de 2. " qualidade.

Hotéis e Restaurantes - Esta classe de retalhistas vende figo e uva sob a forma especial de sobremesa nas refeições. Ela é de pequena importância na venda dessas trutas, pois só os estabelecimentos mais caros apresentam essas frutas em seus cardápios, sendo servida, em geral, fruta de $1 .^{a}$ qualidade.

\section{VENDA}

A venda de figo e uva a retalho é processada de vários modos, segundo a classe de retalhistas. Por êsse motivo, ao descrevermos os diversos aspectos da venda, iremos salientando tais diferenças.

A quem vendem - Os compradores dos feirantes e ambulantes de bairro são, na maioria, pessoas das classes médias e proletária, mas, também, representantes das classes mais abastadas e daí observar-se entre êsses retalhistas grande variação quanto à qualidade e apresentação das frutas ; êsses consumidores são, em geral, fregueses regulares, apesar de, como já acentuamos, não ser hábito da nossa população adquirir assiduamente essas frutas. A maior parte dos compradores das frutarias do centro da cidade são consumidores ocasionais, aos quais chamou a atenção o aspecto da fruta exposta; por serem, em geral, das classes mais abastadas, êstes compradores são mais exigentes quanto à qualidade e embalagem da fruta. Os fruteiros de bairro e quitandeiros quase só vendem aos seus fregueses habituais, os moradores nas vizinhanças.

Hora - A hora da venda também varia com a classe de retalhista. Assim, os feirantes só vendem das 6 às 12 horas. Os fruteiros e quitandeiros vendem desde cedo até a noite, porém a maioria das vendas se efetua antes da hora do almôço. Os ambulantes vendem desde cedo até a tarde, com maiores vendas no período da manhã.

Como vendem - Uma vez com a mercadoria em suas bancas, os feirantes e fruteiros separam a fruta em tipos de diferentes preços e a expõem aos consumidores; as gavetas de figo são retiradas dos engradados e assim expostas; as caixas de uva são abertas e, ou deixadas como foram arrumadas pelos produtores, ou os cachos são retirados para formar pilhas, marcados com diferentes preços. Os ambulantes e quitandeiros, em geral, só abrem os volumes para expor as frutas à venda. 
Nos dias em que a venda é grande e o estoque se escoa ràpidamente, os retalhistas vendem a fruta no estado em que a recebem dos atacadistas sem fazer um arranjamento especial; quando, entretanto, a fruta passa de um dia para outro, êles precisam ir fazendo uma seleção, a fim de separar a fruta que está boa da que já está se estragando: esta última é marcada com um preço mais baixo, se seu estado ainda permite que seja vendida, ou, então, é jogada fora.

A maioria dos consumidores compra a fruta pessoalmente, sendo raras as encomendas por telefone; estas só são feitas pelos poucos fregueses habituais das maiores frutarias e mercearias, e, neste caso, o retalhista entrega a fruta a domicílio por sua conta. Em geral, porém, êles não fazem e nem se encarregam da entrega da fruta na casa do consumidor. As compras são a dinheiro, sendo muito raros os negócios "fiado". O retalhista não cobra nem exige a devolução do vasilhame, quando êste é levado pelo freguês.

Unidades de venda : $O$ figo é vendido no retalho, em gavetas, dúzias e frutos avulsos e a uva a $\mathrm{Kg}$. Para a venda do figo em unidades menores que a gaveta, os retalhistas escolhem as que possuem maior número de frutos, pois, assim, seu ganho é maior. Alguns retalhistas, principalmente os fruteiros do centro da cidade, não vendem quantidades menores que a dúzia de figos e um $\mathrm{Kg}$ de uvas, pois os compradores de pequenas quantidades querem escolher a fruta, apalpam-na inúmeras vêzes e a estragam; sòmente quando os frutos de alguma gaveta já estão meio "passados" é que êsses fruteiros os vendem em qualquer quantidade. Os ambulantes que estacionam em certos pontos da cidade, quase só vendem em pequenas quantidades, isto é, um ou mais figos e um cacho de uvas, pois seus fregueses as consomem no próprio local.

Risco - Os riscos que os retalhistas correm na venda do figo e uva é variável com diversos fatôres. A época de venda é um dêles: no início da safra, por exemplo, quando essas frutas são novidade, sua venda é fácil e quase não há encalhe ; com o avançar da safra, os consumidores já começam a preferir outras frutas, a venda já se torna mais difícil, a fruta "encalha" na banca do retalhista por 2 ou 3 dias, os frutos deterioram ràpidamente, podendo, assim, haver regular prejuizo; esta ocorrência é mais comum com o figo, cuja safra se prolonga por quase 6 meses. Outro fator responsável por perdas e que, portanto, aumenta o risco na venda dessas frutas, é o tempo; assim, um engradado de figos 
colhidos com tempo chuvoso, pode chegar até o retalhista aparentemente em bom estado; basta, porém, uma exposição de algumas horas na banca, para as frutas começarem a se desmanchar e decompor ; neste caso, o prejuizo do retalhista é total se, em tempo, êle não "empurrou" a fruta para algum comprador desavisado. Com relação à uva, o principal prejuizo que têm os retalhistas é com o desbagamento que começa a ocorrer um ou dois dias após a colheita; principalmente as camadas inferiores das caixas, apresentam, depois dêsse período, regular quantidade de cachos desbagados; não só o consumidor exigente reluta em aceitar essa qualidade de fruta que precisa, então, ser vendida a preço mais barato, como há, ainda, a perda total dos bagos sôltos.

Pelas informações que nos prestaram alguns retalhistas, podemos avaliar a média de perdas como sendo de $12 \%$ para o figo e $10 \%$ para a uva.

A fruta imprópria para o consumo é, em geral, jogada fora, pois a quantidade é muito pequena para cada retalhista vendê-la para outros fins.

Volume de vendas - $O$ volume diário de vendas de figo e uva, de cada retalhista, varia segundo sua classe, localização, apresentação das frutas, etc. Já dissemos que os feirantes são os que mais vendem e, segundo algumas informações que dêles obtivemos, na época da safra a venda média é de 20 engradados de figo e 30 caixas de uva, havendo, entretanto, variações, conforme a localização das feiras : assim, os feirantes do largo do Arouche, em geral, vendem mais, pois essa é a feira mais frequentada na cidade; assim também, nas feiras de certos bairros proletários, é provável que a venda dessas frutas seja menor.

A variação do volume de vendas já é maior no caso das frutarias, pois estas diferem bastante umas das outras, seja pela localização, pela variedade de produtos à venda, etc. As pequenas bancas de frutas do centro da cidade, vendem, em média, de 2 a 5 engradados de figo e 5 a 10 caixas de uva, diàriamente ; encontramos, entretanto, algumas dessas bancas bem localizadas em ponto de grande movimento, cuja média diària de venda, em período de plena satra, era de 25 engradados de figo e 50 caixas de uva. É de notar ainda a existência de uma rede de mercearias (Chain-stofes), com secção de frutas em quase tôdas as suas filiais e cuja venda diária atinge, em média, 100 engradados de figo e 200 caixas de uva. As demais classes de retalhistas também apresentam grande variação na quantidade vendida diàriamente, por isso, deixamos de mencionar qualquer número a respeito; devemos notar, entretanto, 
que certas classes, como o ambulante que estaciona em determinado ponto da cidade, chegam a vender quantidades apreciáveis dessas frutas, diàriamente.

\section{DESPESAS DOS RETALHISTAS}

Devido às grandes variações existentes entre as diversas classes de retalhistas com relação aos sistemas de negócio, volume de vendas, classe de fregueses e, principalmente, devido ao variado número de produtos oferecidos à venda, juntamente com figo e uva, as despesas de comercialização dêsses dois produtos variam bastante de um para outro retalhista, mesmo entre os da mesma classe. Por êsses motivos, sòmente por meio de aproximações grosseiras, poderemos determinar - custo dessa comercialização, como faremos em capítulo posterior. Baseados em algumas informações que obtivemos dos retalhistas, iremos apresentar aqui, ùnicamente dados aproximados referentes às despesas de sua comercialização, mostrando, sempre que possível, as que recaem exclusivamente sôbre figos e uvas e as que oneram todo o negócio.

Feirantes - As despesas desta classe de retalhistas são, com maior aproximação que as de qualquer outra, representativas para a classe em geral, pois, como já dissemos, os feirantes apresentam condições de negócio mais ou menos uniformes entre si.

As despesas dos feirantes podem ser grupadas sob dois títulos:despesas fixas - incluindo aquêles itens que, dentro de razoáveis limites, oneram o feirante quase independentemente da espécie de produtos vendidos e do volume de vendas; e - despesas de venda - que estão na estrita dependência do número de volumes vendidos. No quadro XVII estão enumeradas, ítem por ítem, as suas despesas anuais e diárias; considerando como venda média dos feirantes durante a safra de figo e uva, o total de 50 volumes (20 engradados e 30 caixas), apresentamos na última coluna do quadro, as despesas por volume, incluindo os ítens de despesas fixas e de venda. 


\section{QUADRO XVII}

DISCRIMINAÇAO DAS DESPESAS DOS RETALHISTAS

\begin{tabular}{|c|c|c|c|}
\hline \multirow{2}{*}{ I T EN S } & \multicolumn{2}{|c|}{ DESPESAS FIXAS } & \multirow{2}{*}{$\begin{array}{l}\text { Despesa por } \\
\text { volume }\end{array}$} \\
\hline & Anuais & Diárias & \\
\hline \multirow[t]{2}{*}{ 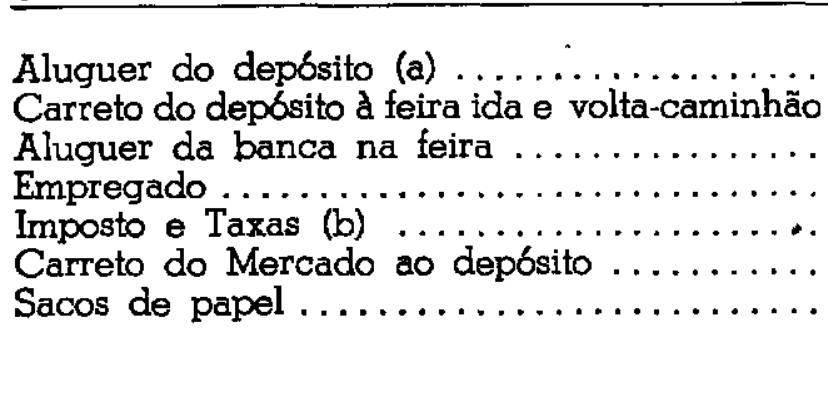 } & $\begin{array}{c}\text { Cr\$ } \\
1.080,00 \\
10.800,00 \\
792,00 \\
4.320,00 \\
131,50 \\
=\end{array}$ & $\begin{array}{c}\text { Cr. } \$ \\
3,00 \\
30,00 \\
2,17 \\
11,83 \\
0,36 \\
-\end{array}$ & $\begin{array}{l}\text { Cr.\$ } \\
0,06 \\
0,60 \\
0,043 \\
0,24 \\
0,005 \\
0,20 \\
0,64\end{array}$ \\
\hline & $17.123,50$ & 47,36 & 1,788 \\
\hline
\end{tabular}

(a) Os feirantes se reunem em grupos e alugam um depósito perto do Mercado Municipal, onde guardam seus apetrechos, depositam a mercadoria que compram à tarde no Mercado para revender no dia seguinte e a que sobra de um dia para outro.

(b) Estes impostos e taxas compreendem: Alvará de registo de Alimentação Pública ; Licença Municipal; imposto de Indústrias e Profissões.

Êste cálculo de despesa por volume não é bem exato, pois os feirantes, ao mesmo tempo que figos e uvas, vendem outras frutas; como, entretanto, nessa ocasião o volume de vendas dessas outras frutas é pequeno, podemos, sem grande êrro, fazer recair sôbre essas duas frutas o total da despesa diária ; convém, entretanto, ter em mente que a quantia encontrada - Cr\$ 1,788 - seria menor se a despesa total fôsse convenientemente repartida entre todos os produtos vendidos.

Por uma rápida análise, vemos que alguns ítens são dos que mais sobrecarregam essas despesas; assim, o carreto do depósito à feira é um dos maiores, principalmente devido ao racionamento de gasolina que fêz triplicar o preço dêsse serviço: Antes da guerra, os motoristas cobravam $\mathrm{Cr} \$ 300,00$ mensais para fazer êsse serviço e transportavam o material de um único feirante; hoje, cobram Cr\$900,00 mensais e fazem num só carreto, o transporte de 3 e 4 feirantes. Outra despesa elevada é a com empregado, apesar de a termos computado à base do salário mínimo; muitas vêzes, o salário é maior que o mínimo estatuído por lei, por ser um trabalho pesado e que exige bastante atividade. Finalmente, a despesa mais elevada, é a com sacos de papel, nos quais a fruta é entregue ao consumidor ; também êsse ítem de despesas aumentou a guerra, com o encarecimento enorme que teve o papel. Um ponto a notar é que as despesas com impostos e aluguer da banca são as menores de tôdas, sendo mínima a incidência de impostos. 
Fruteiros - Já se apresenta mais difícil dar as despesas da comercialização dos fruteiros devido às grandes variações que apresentam em seus negócios. Principalmente a localização e o número de produtos expostos à venda, são fatôres que concorrem para tornar quase impossível dar uma quantia que seja representativa das despesas dos fruteiros em geral ; assim, conforme a localização da frutaria, variam bastante o aluguer, os impostos, o custo da embalagem, o volume de vendas, etc.; também a diversidade dos produtos expostos à venda faz variar a percentagem de despesas que deve recair sôbre cada artigo. Por êsses motivos, é difícil calcular o custo da comercialização dêstes retalhistas. As informações que tivemos a respeito das despesas dos mesmos, além de serem poucas, não cobriram todos os tipos de fruteiros. Entre. tanto, a fim de mostrar o que representam essas despesas, vamos transcrever os dados que obtivemos de um fruteiro estabelecido no centro da cidade, com banca à porta de um café e bar e que, além dessas duas frutas, vendia outras, nacionais e. estrangeiras, doces em pacotes e em latas, queijos e conservas ; o movimento médio de suas vendas, era de 10 caixas de uvas e 5 engradados de figos por dia, além de venda de outros artigos. Esse volume de vendas pode ser considerado representativo para grande parte dos fruteiros da cidade, que têm condições de negócio mais ou menos semelhante às do nosso informante.

Aqui vamos separar essas despesas em dois quadros: a) dados relativos às despesas fixas anuais que oneram todo o negócio; b) dados referentes às despesas diretas provenientes da venda de figo e uva.

\section{QUADRO XVIII}

DISTRIBUIÇAO DAS DESPESAS FIXAS DE UM FRUTEIRO DO CENTRO DA CIDADE

Despesas anuais

Aluguer da banca $(20 \mathrm{~m}$ ')

Empregados (dois)

$\mathrm{Cr} \$$

Impostos e taxas :

Indústrias e Profissões

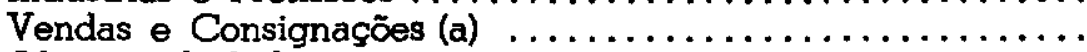

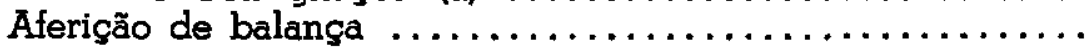

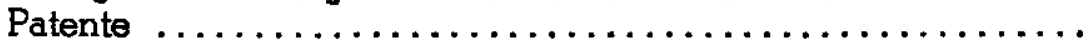

Sindical

Instituto de Aposentadorias

Âlimentação Pública.

$15.000,00$

$12.000,00$

Licença da Prefeitura

$3.000,00$

$2.200,00$

42,50

140,00

20,00

756,00

75,00

363,00

Total

Cr.\$33.596,50

(a) Cálculo aproximado. 
Como se vê, não é pequena a despesa de um fruteiro nas condições acima, devendo-se notar que grande parte delas são, dentro de certos limites, independentes do volume de vendas. Entre outras despesas não relacionadas no quadro XVII, estão as com iluminação, anúncio (letreiro), avental branco para os empregados (obrigatório), telefone, etc.

Com relação a certos ítens, devemos fazer alguns esclarecimentos. aluguer da banca, por exemplo, é um ítem bastante variável, pois, só no centro da cidade, encontramos preços que variavam de 50 a 250 cruzeiros o metro quadrado, conforme melhor ou pior localização e as dimensões da banca; também nos bairros, os preços variam segundo a classe. $O$ ítem empregado é obrigatório em quase tôdas as frutarias, pois o dono da banca não pode aí permanecer durante todo o tempo: além das horas de refeições, êle é obrigado a se ausentar diàriamente durante algumas horas para a compra de frutas no Mercado; ao menos um empregado, as frutarias têm que manter.

Os impostos de "Indústrias e Profissões" e "Vendas e Consignações", assim como a taxa devida ao Instituto de Aposentadorias, são variáveis com o volume de negócios do estabelecimento; além disso, o de Indústrias e Profissões também varia conforme os artigos vendidos : o imposto é lançado sôbre a venda de uma classe de artigos (a principal) sendo cobrada para as demais uma taxa adicional, variável com o número e classe de artigos. Esta última disposição tem favorecido o estabelecimento de bancas de frutas em certos negócios como as mercearias que, mediante o pagamento de um pequeno adicional, ampliam sua linha de produtos à venda, estabelecendo, contudo, uma concorrência desvantajosa para as frutarias, pròpriamente ditas, que pagam um imposto proporcional bem mais alto.

No quadro XIX estão relacionadas as despesas provenientes diretamente da venda de figo e uva: são as despesas com transportes e embalagem. $\left(^{*}\right)$

Também essas despesas não são iguais para todos os fruteiros, pois, conforme o estabelecimento, varia a qualidade dêsses serviços ; assim, as frutarias do centro da cidade, em geral, fazem uma boa embalagem, pois sua freguesia é mais exigente: nas compras superiores a duas dúzias de figos e $2 \mathrm{Kg}$ de uvas, a fruta geralmente é colocada num prato de papelão, cujo custo atual não é baixo; já os fruteiros dos bairros, geralmente, só fornecem um saco de papel.

(") Está excluída a despesa com o imposto de vendas e consignações, já computado no quadro de despesas fixas. 
As quantias aqui apresentadas são as que oneram uma caixa de uvas e um engradado de figos vendidos a $\mathrm{Kg}$ e dúzias, respectivamente, sendo os serviços computados aos preços vigentes no ano de 1944.

QUADRO XIX

DISCRIMINAÇAO DAS DESPESAS DIRETAS DE VENDA DOS FRUTEIROS

I T E N S $\quad . \quad$ Despesas por volume (a)

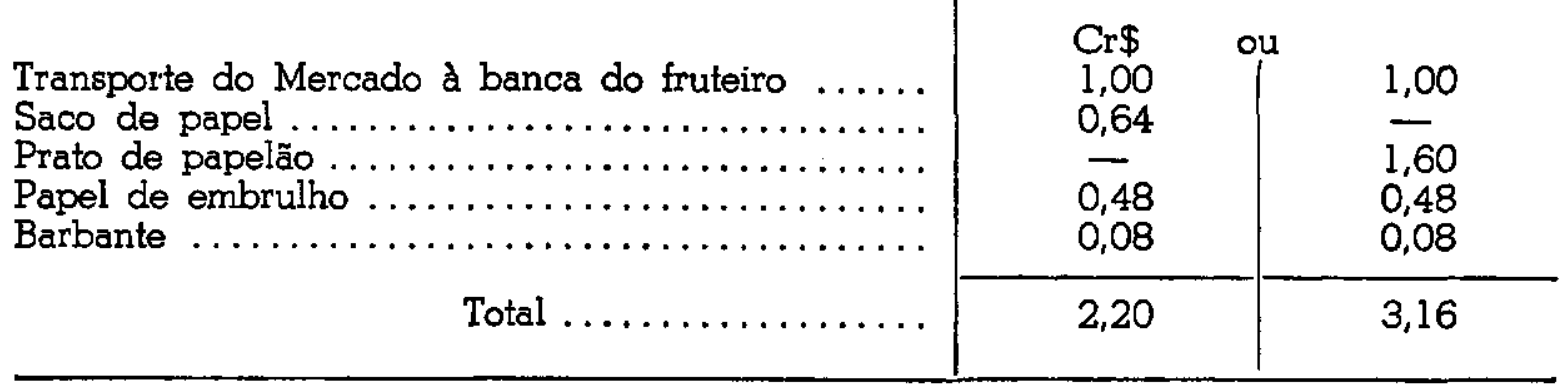

(a) Essas despesas vão relacionadas em duas colunas porque quando é usado um prato de papelão, em geral, é dispensado o saco de papel.

Ambulante - As despesas desta classe de retalhistas se resumem na amortização de uma carrocinha e um animal, e aos impostos e taxas. Não ocorrem aqui, as despesas de venda (transporte, embalagem), já que os retalhistas vão buscar a fruta no Mercado e a vendem sem qualquer embalagem, pois ou são consumidas na hora da compra (ambulante com ponto de estacionamento) ou a venda é feita à porta dos consumidores. A maior parte dos impostos estaduais e municipais que sôbre êles pesavam foram abolidos em $1944\left(^{*}\right)$; só restam algumas taxas : Instituto de Aposentadorias ( $\mathrm{Cr} \$ 294,00$ anuais) e sindical ( $\mathrm{Cr} \$ 20,00$ mensais).

Quitandeiros - Nada poderemos dizer sôbre as despesas dos quitandeiros por ser um cálculo ainda mais difícil do que aquêle apontado para os fruteiros (variação de despesas decorrentes da localização, variedade de artigos vendidos, impostos, etc.), além de ser esta classe de pequena importância na venda de figos e uvas.

Como vemos, são poucos os dados que conseguimos obter a respeito das despesas dos retalhistas na comercialização de figos e uvas, devido

(*) Decretos n. 13.859, de 2-3-1944 da Interventoria Federal e n. 256 de agôsto de 1944, da Prefeitura Municipal. Foram abolidos os impostos de : Indústrias e Profissões, Vendas e Consignações, Licença Municipal e Imposto de Véículos; alem disso, foi dispensado de selagem, o Alvará de registo na Inspetoria de Alimentação Pública. Até a decretação dessas medidas, o montante de despesas com impostos era de $\operatorname{Cr} \$ 676,00$ anuais para os ambulantes com tração manual e $\mathrm{Cr} \$$ 988,00 anuais para os ambulantes com tração animal. 
aos motivos já apontados anteriormente. Como em capítulo posterior trataremos do custo de comercialização geral de figo e uva, limitamo-nos agora a essas indicações sôbre as despesas dos retalhistas. Todavia, podemos notar, desde já, a grande diferença entre as despesas dos fruteiros e feirantes, pois enquanto os $1 .^{\text {os }}$ têm grande despesa fixa, a dos feirantes lhes é inferior em mais de 50\%; de tal modo é essa diferença que a despesa total por volume de feirante $(\mathrm{Cr} \$ 1,79)$ é ainda menor, que só a despesa de venda do fruteiro $(\operatorname{Cr} \$ 2,20)$. Com relação aos ambulantes, então, as diferenças são ainda maiores, pois as despesas dêstes são, atualmente, mínimas.

\section{PREÇOS}

Uma vez descrito como se processa a comercialização de figos e uvas, poderemos, então, tratar da questão dos preços destas frutas.

Infelizmente, são escassos os dados de que dispomos sôbre preços, - que nos impede de fazer uma análise mais aprofundada da questão; entretanto, com os poucos dados que possuimos e mais com o conhecimento das práticas dêsse comércio, poderemos fazer algumas conside. rações sôbre os aspectos mais importantes do assunto em aprêço.

Devemos, primeiramente, distinguir as diversas classes de preços existentes nesse comércio e precisar as relações existentes entre elas.

Despresando as variações devidas às diferentes variedades, tipos, unidades de venda, etc. $\left(^{*}\right)$, pcdemos distinguir no comércio de figo e uva, três classes de preços: há o preço que o lavrador recebe do atacadista (preço do produtor), o preço que êste recebe do retalhista (preço do atacado), e o preço que o retalhista recebe do consumidor final (preço do retalho). Se limitarmos a expressão "mercado" ao local onde se dá uma transferência de título da mercadoria, podemos distinguir, nesse comércio, três mercados, a cada um dos quais corresponde um daqueles preços e que podemos chamar de mercado do produtor $\left(^{\star \star}\right)$, do atacadista e do retalhista.

Apesar de diferentes, essas três classes de preços não são independentes entre si, porque os três mercados se distribuem de tal modo que o preço de um dêles tem uma certa relação com o do mercado que o antecede e com o que o segue no canal de distribuição. Tanto é assim,

(") Analisaremos mais adiante algumas destas variações.

(") Este mercado só existe no caso de venda, a "preço fixado", pois, quando em consignação, a transferência de título só se dá no mercado atacadista; entretanto, para os fins desta análise, não há inconveniente em generalizar êsse conceito para todos os negócios dos produtores, sejam a "preço fixado" ou não. 
Gráfico I

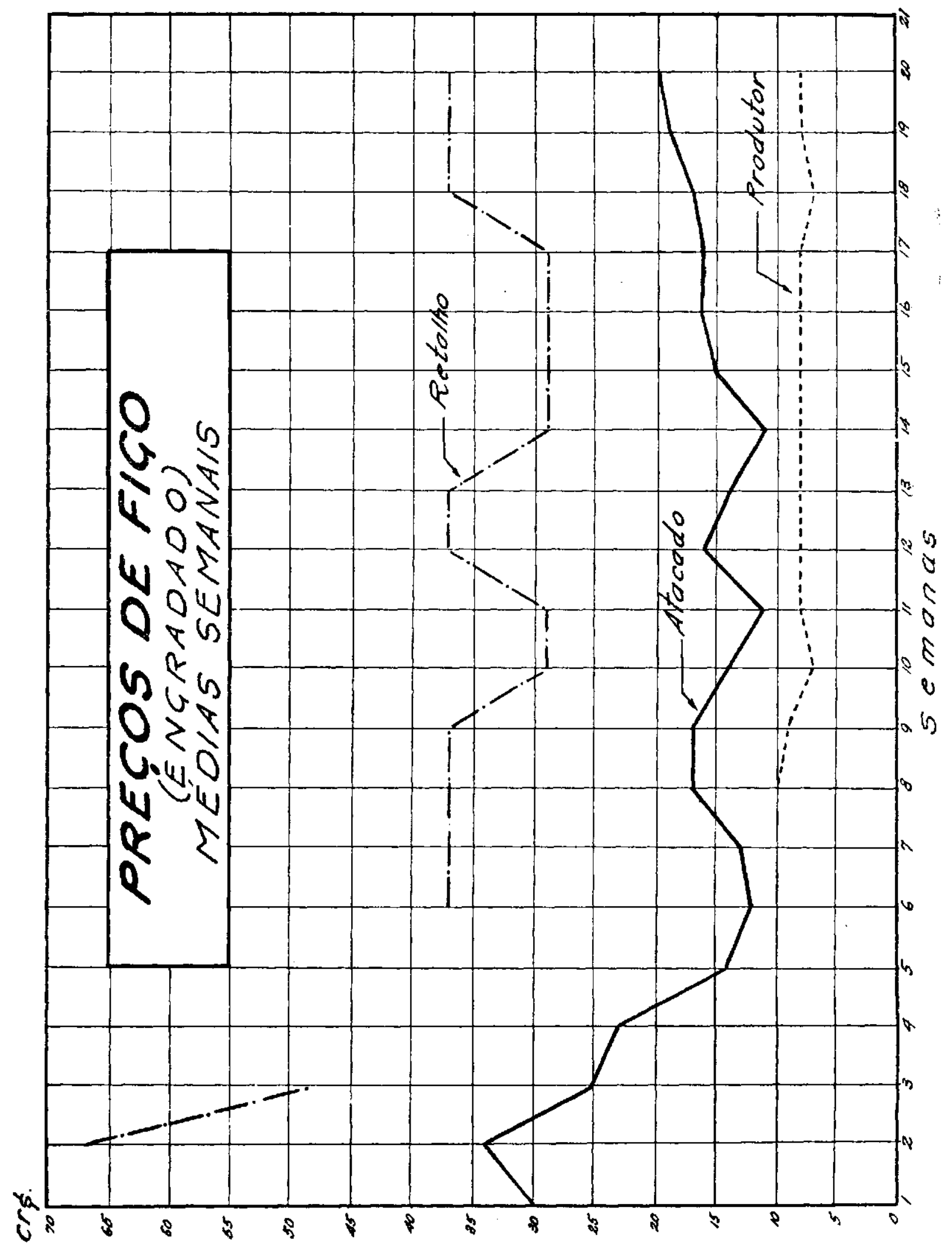


Gráfico II

Cri

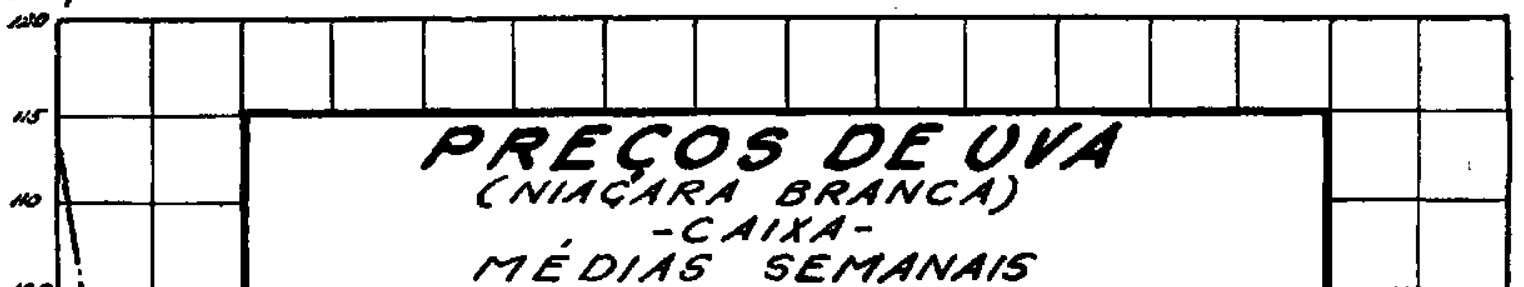

10

8

35

90

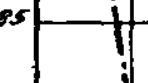

.

$$
\text { ; }
$$

5

6

5

5

$\infty$

2

$$
2
$$

10

10

5

MEDIAS SEMANAIS 
que se pode dizer que o preço do atacado é igual ao que o produtor recebeu, mais o custo da comercialização do atacadista, e também, que - preço do retalho é igual ao do atacado mais o custo da comercialização do retalhista; ou, ainda, que o preço pago pelo consumidor final, diminuído dos custos da comercialização (transportes, vasilhame, impostos, etc. e lucro dos intermediários), é igual ao preço recebido pelo produtor.

Essa dependência entre os preços dos diversos mercados nem sempre pode ser expressa por uma relação bem definida; é o que acontece, por exemplo, quando as margens de negócio variam com os preços do produto no mercado. E é isso que se dá com o figo e a uva, conforme se pode verificar nos gráficos I e II, que representam as médias semanais de preços recebidos pelos produtores, atacadistas e retalhistas, durante a safra de 1943-44 ( $\left(^{*}\right)$. Observando-se êsses gráficos, verifica-se que apesar de os preços dos diferentes mercados guardarem um relativo paralelismo entre si (o que é indício da dependência há pouco descrita), existem épocas (início da safra, por exemplo) em que as diferenças entre os preços de dois mercados contíguos são maiores e outras (meio de safra, por exemplo) em que essas diferenças diminuem. $\left(^{* \star}\right)$

Pode-se notar também na relação de preços diários (quadros XXVII e XXVIIJ), que durante períodos mais ou menos longos, que vão até mais de uma semana, os preços do retalho permanecem os mesmos a despeito das variações quase diárias que ocorrem no atacado, ou, então, que a amplitude das variações do retalho são bem menores que suas correspondentes no atacado. Esta pequena variação dos preços, é típica do mercado retalhista e, no caso dessas duas frutas, pode ser explicada por diversos motivos: um, é que o consumidor não segue as variações do mercado e por isso oferece tôda resistência a variações nos preços dos artigos que compra e êsse fato precisa ser levado em consideração pelos retalhistas ao marcarem seus preços de venda; outro motivo é que para ficar a coberto de prejuizos com as variações dos preços no atacado, já é suficientemente grande a margem cobrada pelo retalhista; geralmente, as variações de preço do atacado representam uma percentagem mínima quando expressa nas unidades de venda do retalhista e a margem dêstes já é suficiente para cobrir pequenas quantias como essa. Finalmente, a remarcação diária dos preços de todos seus produtos é dificultosa e causa confusão aos próprios retalhistas.

Se se observar a linha dos preços do retalho, constata-se que mesmo no período de plena safra o preço da uva não desceu a menos de $\mathrm{Cr} \$$

(') Ver a origem dêstes dados à página 44 ?.

(*) Ver adiante, o capítulo referente a margens e lucros dos intermediários. 
5,00 ० $\mathrm{Kg}$ e o figo, a menos de $\operatorname{Cr} \$ 7,00$ a gaveta, sendo a maioria dos preços superiores a essas cotações. Comparando-se êsses preços com os de outras frutas de maior consumo entre nós (banana, laranja), verifica-se que, na realidade, os preços de figo e uva são bastante elevados para a maioria de nossa população, que só ocasionalmente poderá consumí-las.

As causas dêste preço elevado são, aliás, das questões mais discutidas entre os interessados neste comércio, e, também, principalmente entre os consumidores. Assim é que êstes, em geral, estão propensos a acreditar que o alto preço não só dessas duas frutas como também o de outras, tem sua principal origem na ganância dos intermediários que, aproveitando-se de sua posição privilegiada e de circunstâncias favoráveis, controlam de tal forma os mercados de modo a auferir altos lucros, ou, então, na ambição dos produtores, que querem amortizar o capital empatado em suas plantações à custa de uma única safra.

De outro lado, já mostramos, no estudo da comercialização pelos produtores, que êstes pouco aproveitam com a elevação de preços, devido ao seu fraco poder de negociações frente aos intermediários.

Em virtude dessas controvérsias, é de todo interesse que se tente elucidar agora as causas do alto preço e o motivo por que os produtores. não lucram quanto deviam, quando há elevação de preços. Para isso, entretanto, seremos obrigados a esclarecer diversas questões preliminares, cuja análise nem sempre está ao alcance da maioria do público. Ainda que nos tome um longo espaço, acreditamos que isso se justifique. pela importância do assunto.

Sabemos que os preços de um produto são, principalmente, a resultante da interação de fôrças ou fatôres que se estudam sob os nomes de oferta e procura e seus níveis dependem da posição que guardam entre si essas duas curvas. Dêsse modo, as causas do alto preço dessas frutas devem ser pesquisadas em primeiro lugar entre as fôrças que afetam a forma e a posição dessas curvas. E é o que faremos a seguir, ao estudar os fatôres que compõem a oferta e procura de figo e uva entre nós.

Em seguida, devemos pesquisar o sistema em que se estabelecem. os preços, como, por exemplo, se o mercado funciona sob competição pura ou não, pois sabemos que existem certas condições que possibilitam um contrôle do mercado por parte de certas pessoas, o que dá em resultado uma elevação nos preços. 
Iremos, então, estudar separadamente cada um dêsses setores, e no decorrer dêstes estudos as razões do alto preço e do fraco poder de barganha dos produtores ficarão patentes por si mesmas.

\section{FATÔRES QUE COMPÕEM A OFERTA E PROCURA}

Sendo os preços, principalmente, uma resultante da interação de fôrças ou fatôres que compõem a oferta e procura, é de se esperar que as variações que ocorrem contìnuamente nessas fôrças sejam as principais responsáveis pelas alterações nos preços.

Daí o interêsse em verificar quais as principais fôrças que compõem a oferta e procura de figo e uva e como, por suas variações, são afetadas a posição e a forma dessas curvas. Só iremos fazer considerações sôbre as fôrças que nos parecem ser as de maior importância, pois são escassos os dados estatísticos de que dispomos para medir a ação de cada uma delas sôbre a oferta e procura de figos e uvas.

É fato de fácil constatação que os preços de figo e uva variam, não só entre períodos longos de tempo, como de uma safra para a seguinte, como, ainda, de um dia para outro, e, em mais curto espaço de tempo, ou seja, dentro do mesmo dia. Devido sua importância, ao menos duas espécies de variações nos interessa estudar aqui : a) a variação do preço médio da safra e que podemos chamar de "variação do preço anual" ; b) a variação que ocorre de um dia para outro e que chamaremos de "variação do preço diário".

Não temos dados para mostrar a ocorrência da variação do preço anual, mas é bem sabido que os preços médios dessas frutas são ora baixos e ora mais altos em uma safra do que em outras. Com relação à variação dos preços diários, os dados dos quadros XXVII e XXVIII mostram bem sua amplitude.

Como as fôrças que afetam os preços anuais de figo e uva nem sempre são as mesmas que influem nos preços diários, vamos mostrar, separadamente, quais os principais fatôres que afetam cada um dêsses preços.

\section{Fatôres que afetam os preços anuais}

Entre os mais importantes fatôres que afetam os preços anuais destas frutas e são, portanto, responsáveis pelas variações que nêles ocorrem, podemos apontar os seguintes: 
a) - Quantidade total produzida no ano - E o principal fator da oferta dessas frutas, porque não existe "carry over", nem importação apreciável do estrangeiro nessa época. A influência dêsse fator sôbre os preços é por todos reconhecida, tanto que a chamada "lei de procura", expressa: "quanto maior a quantidade de um produto oferecida no mercado em um dado momento, menor será o preço unitário pelo qual tôda a produção será vendida". Devido à insuficiência de dados, é difícil não só medir a relação existente entre a produção e o preço anual dessas frutas, nos anos passados, bem como mostrar a simples confirmação da tendência anunciada acima, entre volume da produção e preço. Entretanto, é nossa observação pessoal, aliás confirmada pela dos negociantes, que a oferta dessas frutas tem aumentado bastante nos últimos anos; e, ao contrário do que então se deveria esperar, os preços de figo e uva se têm elevado; como se verá logo mais, isso se deve ao fato de que a procura também tem aumentado, e em maior proporção que a oferta.

b) - Duração da safra - Por estar muito dependente das condições de clima, a duração da safra destas frutas varia bastante e isso pode afetar o preço anual. Assim, o amadurecimento muito rápido da safra de uva da zona, pode causar, durante certo período, um congestionamento do mercado, além dos limites de consumo, causando uma baixa nos preços durante êsse período e isso afetará o preço médio da safra. A safra de figo também pode, em certos anos, se estender além do normal, devido às condições de clima; quando isto acontece, essa prcdução tardia já vai concorrer com outras frutas, em plena produção, e o resultado pode ser um abaixamento do preço médio da safra.

c) - Poder aquisitivo da população - As variações dêste fator da procura podem também causar variações nos preços anuais. Atualmente, ainda que o figo e uva pareçam ser muito do gôsto do nosso povo, o seu preço é elevado para grande parte da população que ainda possui baixo poder aquisitivo; êste fato pode ser comprovado por serem estas frutas consideradas "sobremesa" entre nós, não podendo ser comparadas com a banana, por exemplo, que faz parte da refeição diária da maioria de nossa população. Apesar disso, acreditamos que tenha havido nestes 2 ou 3 últimos anos um aumento na procura destas, devido à entrada de novos consumidores, no mercado, que tiveram suas rendas aumentadas em virtude da atual situação financeira criada pela guerra. $O$ aumento da renda de algumas classes da população, resultou num 
aumento da procura em proporção maior que a oferta de figo $e$ uva, 0 que concorreu sobremaneira para elevar bastante o preço anual.

d) - Hábito de consumo - É outro fator da procura, cujas mudanças podem causar variações no preço anual. Qualquer mudança nos hábitos de consumo de frutas da população se traduzirá em mudança na procura, o que, por sua vez, afetará os preços. Acreditamos que o hábito de consumo de figos e uvas tem aumentado contìnuamente entre nosso povo e isso devido à ação de diversos fatôres.

Um dêles, por exemplo, é o instinto de imitação. É sabido que uma elevada percentagem de nossa população é constituída por estrangeiros, principalmente italianos, portugueses e sírios, em cujos países de origem, estas frutas são muito populares; êsses estrangeiros tornaram-se não só grandes consumidores de nosso figo e uva, como transmitiram êste hábito a seus descendentes $e$, ainda, pelo exemplo, têm incentivado os nacionais e se habituarem ao seu consumo. Outro fator tem sido a pro. paganda, pois essas duas frutas se beneficiam de um modo indireto, com a campanha dietética que tem sido feita, mostrando as vantagens da inclusão de frutas no regime alimentar da população. Finalmente, o aumento é também o resultado da apresentação cuidadosa e mais ou menos estandardizada com que figos e uvas têm sido oferecidos ao consumo de alguns anos a esta parte o que, indiscutivelmente, contribuiu para despertar a atenção e o desejo de muitos novos consumidores que se habituaram, desde então, a comprar estas frutas.

e) - Concorrência que oferecem frutas semelhantes produzidas na mesma época - É outro fator cujas variações afetam a procura e, por conseguinte, o preço anual. Se duas ou mais frutas semelhantes são vendidas no mercado na mesma época, é natural que o consumo de uma delas se faça em prejuizo do consumo da outra; e o aumento do hábito de consumo de uma, resultará, no fim, em uma baixa no preço da outra. Às vêzes, essa concorrência pode ser momentânea ; assim, duas frutas podem tornar-se concorrentes devido apenas à precocidade eventual na maturação de uma delas. Outras vêzes, a ação dêste fator perdura por um tempo maior : é o que ocorreu com a uva de procedência americana e portuguêsa, que concorriam em nosso mercado com a uva argentina ; devido à guerra, aquelas duas desapareceram do mercado, beneficiando, assim, a uva argentina, cujos preços se elevaram.

A uva nacional sofre pequena concorrência, pois a época de sua safra é muito curta e nessa ocasião quase não existem frutas nacionais 
em franca produção a não ser o figo, também produzido em Valinhos, e que talvez seja a sua concorrente mais séria. A uva argentina que lhe poderia fazer maior concorrência, só tem entrado no mercado no fim da safra da zona de Valinhos e Louveira; além disso, a uva argentina é de preço sempre mais elevado que a nacional, só podendo ser consumida quase ùnicamente por pessoas de classes econômicas mais elevadas. Devemos ainda anotar que, na opinião dos comerciantes de uva, a maior parte da população tem, atualmente, preferência decidida pela uva nacional tipo Niagara, não só por seu sabor como pela sua maior quantidade de caldo.

O figo já se apresenta em situação um pouco diferente da uva quanto à concorrência. A duração de sua safra é maior (dezembro a maio), de modo que concorre com outras frutas que já estão em produção nesse período; entre estas, encontram-se a laranja, produzida em larga escala entre nós e vendida a preço relativamente baixo, o que a torna bastante popular. A uva argentina, que entra no mercado no fim da safra da uva nacional, também concorre para desviar do figo uma parte dos consumidores, principalmente os das classes mais ricas. No início de abril, os consumidores, em geral, já estão cansados de figo e desejam variar de frutas; e êste desejo coincide com a entrada da safra de outras frutas, como laranjas, abacates e caquis, para os quais os consumidores são desviados. Talvez o maior concorrente do figo seja a uva também produzida na zona, pois, apesar de, por unidade, ser mais cara que o figo, é de maior consumo entre nós, o que se comprova com as estatísticas de desembarque em São Paulo e que representam bem o consumo da Capital. Devemos, entretanto, pôr em destaque o fato de que é re. cente a introdução do figo em nosso mercado consumidor, de modo que a maior preferência do público é para as frutas a que está mais acostumado, como a uva.

f) - Variações no poder aguisitivo da moeda - Independentemente de sua oferta e procura, o preço anual destas frutas também varia devido às mudanças no poder aquisitivo da moeda. A variação que tem ocorrido no valor interno de nossa moeda, principalmente durante o estado de guerra, é uma das principais responsáveis pela alta dos preços em geral, inclusive de figo e uva. Por não termos índices de preços anuais de figos e uvas, não nos é possível analisar até que ponto a alta em seus preços é devida à variação no poder aquisitivo interno da moeda; como, entretanto, os índices dêste último valor mostram que nêle houve grande queda, é muito provável que a alta que se 
verificou nos preços dessas frutas nos dois últimos anos, seja, além da situação da oferta e procura já aqui exposta, também, e, principalmente, um reflexo da baixa no poder aquisitivo interno da moeda.

Fatôres que afetam os preços diarios - Entre os fatôres que afetam os preços diários de figos e uvas e, portanto, são responsáveis pelas suas variações, podemos assinalar os seguintes:

a) - Quantidade de figo e uva desembarcada diàriamente em São Paulo : É êste fator da oferta, o mais decisivo no estabelecimento do preço diário o responsável por suas variações. Sabemos que as condições de produção variam de um para outro agricultor, de modo que a quantidade total de fruta colhida e embarcada varia bastante de um dia para outro. Como o consumo diário é mais ou menos constante e como não há armazenamento destas frutas, a quantidade chegada diàriamente é o principal fator que vai afetar o preço do dia.

b) - Estoque - Apesar de estas frutas não poderem ser guardadas mais que 2 ou 3 dias, pelo perigo de deterioração, a ação dêste fator da oferta é notada na determinação do preço do dia. $O$ atacadista, ao fazer o prognóstico do preço do dia, leva em conta, não só a quantidade desembarcada na data, como, também, o estoque do mercado (que é mais ou menos conhecido). Em certas ocasiões excepcionais, por exemplo, quando os trens de frutas atrasam um dia ou mais, o estoque existente no mercado, assume, então, um papel preponderante no estabelecimento do preço do dia.

c) - $\mathbf{A}$ aproximação de datas festivas - É fator que acusa aumento de procura, e que, naturalmente, exerce marcada influência nos preços diários. No quadro de preços de figo e uva de 1943-44, que apresentamos em apêndice, se poderá notar que há uma elevação de preços nas vésperas de datas comemoradas por todo o povo; tais são os casos de Natal e Ano Bom, quando aumenta a procura dessas frutas, pois todos querem adquirir alguma coisa melhor que o comum de todo o dia para a festa em família; da mesma forma, aos sábados e domingos, há maior procura, tendendo os preços para alta nesses dias.

d) - O estado do tempo - É outro fator que, causando modificações na procura, resulta em variações nos preços diários. Em dias chuvosos, por exemplo, os atacadistas sabem que haverá menor pro- 
cura, pois os feirantes e ambulantes que são fregueses habituais, quase não compram devido a dificuldades que têm na venda, em tais dias; daí o preço tender a cair nessas ocasiões.

Com essa análise dos vários fatôres que afetam os preços anuais e diários de figo e uva, verifica-se que os altos preços atingidos atualmente por essas frutas são devidos, em grande parte, às próprias condições da oferta e procura. A oferta anual desta fruta tem sido insuficiente para satisfazer a procura; esta última tem aumentado bastante recentemente, devido, em particular, ao maior poder aquisitivo de certas classes da população, aliado ao aumento do hábito de consumo de frutas; alterou-se então a situação entre as curvas da oferta e procura, estabelecendo-se os preços em níveis mais altos. Apesar de também estar em aumento a oferta, seu crescimento é mais demorado, pois os produtores, em geral, estão pouco informados sôbre as condições do mercado, porque são necessários 3 a 4 anos para que os produtos de uma plantação nova sejam postos no mercado; e, também, porque nem todos os produtores tomam, ao mesmo tempo, a resolução de aumentarem suas plantações.

Por essa análise, somos também levados a concluir que a queda do valor aquisitivo interno de nossa moeda é um dos fatôres que mais devem ter contribuído para a elevação de preços dessas frutas.

\section{SISTEMAS EM QUE SE ESTABELECEM OS PREÇOS}

Já dissemos que as causas do alto preço também devem ser pesquisadas no estudo dos sistemas em que êsses preços são estabelecidos, pois o livre jôgo das fôrças da oferta e procura pode ser alterado por diversos modos, dependendo das condições em que os mercados funcionam.

É sabido que os preços de um produto se estabelecem diferentemente em um mercado, conforme funcione êsse mercado sob condições de monopólio, de competição monopolística ou de competição pura. Assim, dadas as mesmas condições de oferta e procura, o preço de equilíbrio será um, sob condições de monopólio, outro, sob competição monopolística, e ainda outro sob competição pura. 


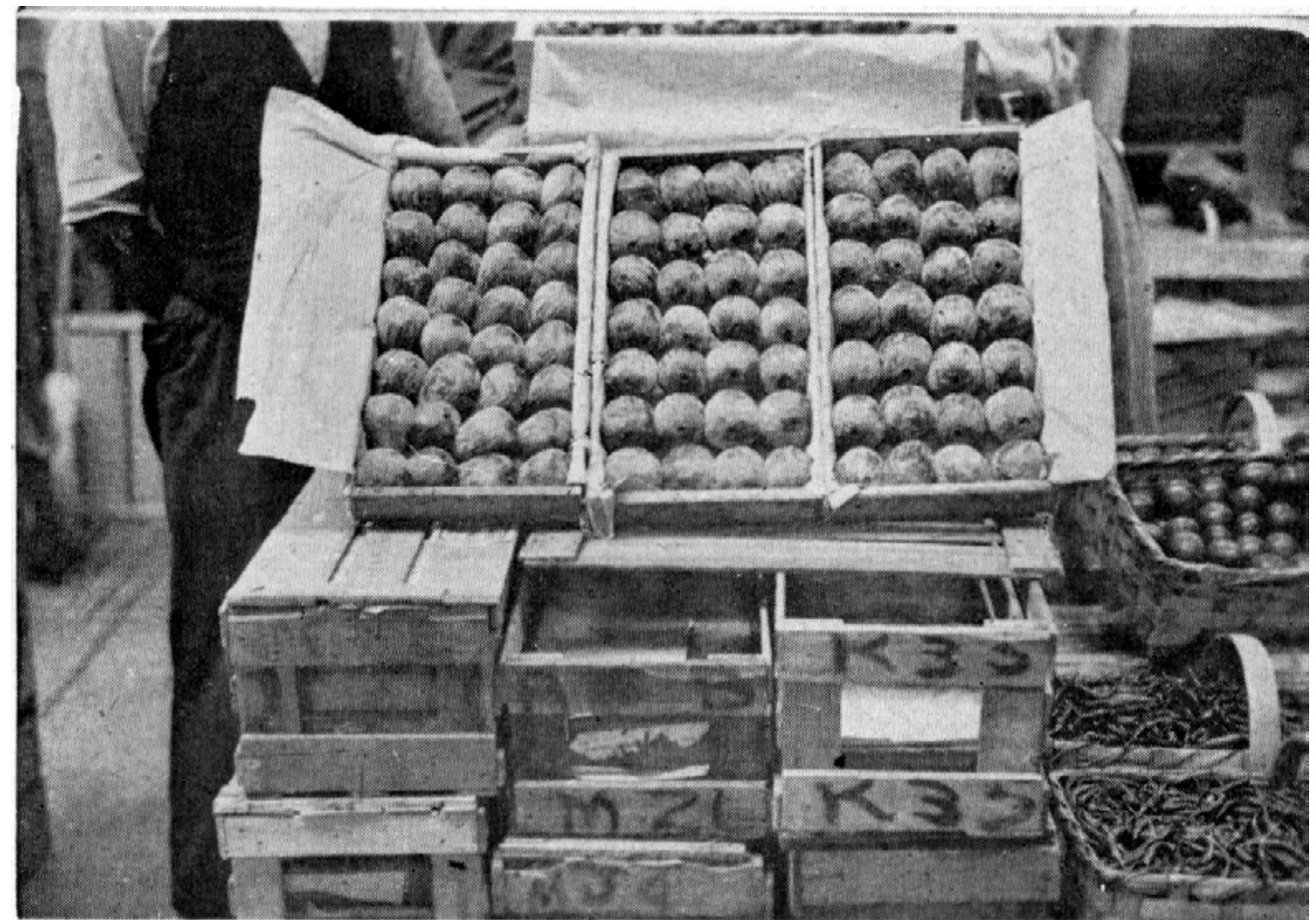

Fig. 10 - As três gavetas de um engradado de figos expostos na banca do atacadista. Embalagem boa, apesar de a gaveta da esquerda pessuir maior número de frutos gue es outras duas. (Foto G. Comparini)

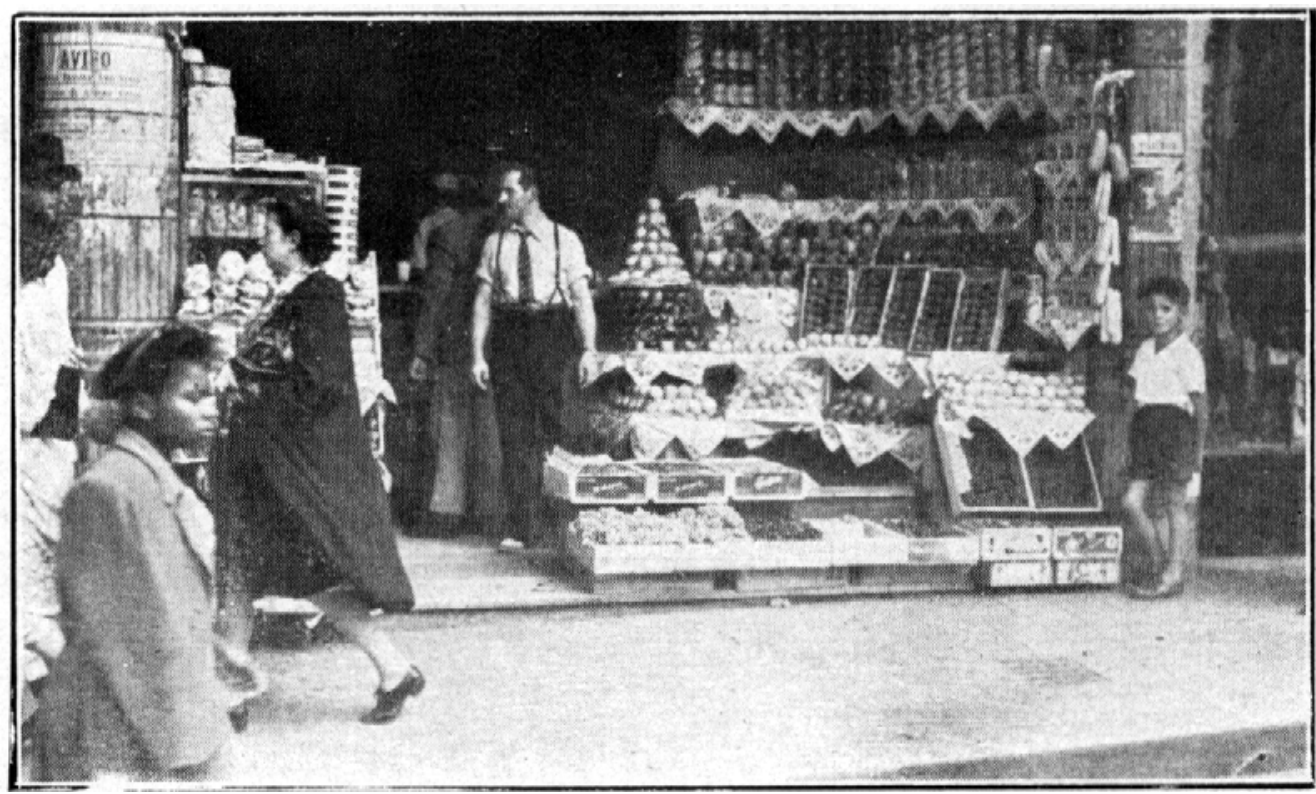

Fig. 11 - Banca típica de um fruteiro no centro da cidade. Pode-se notar a variedade de produtos expostos à venda. (Foto G. Comparini) 


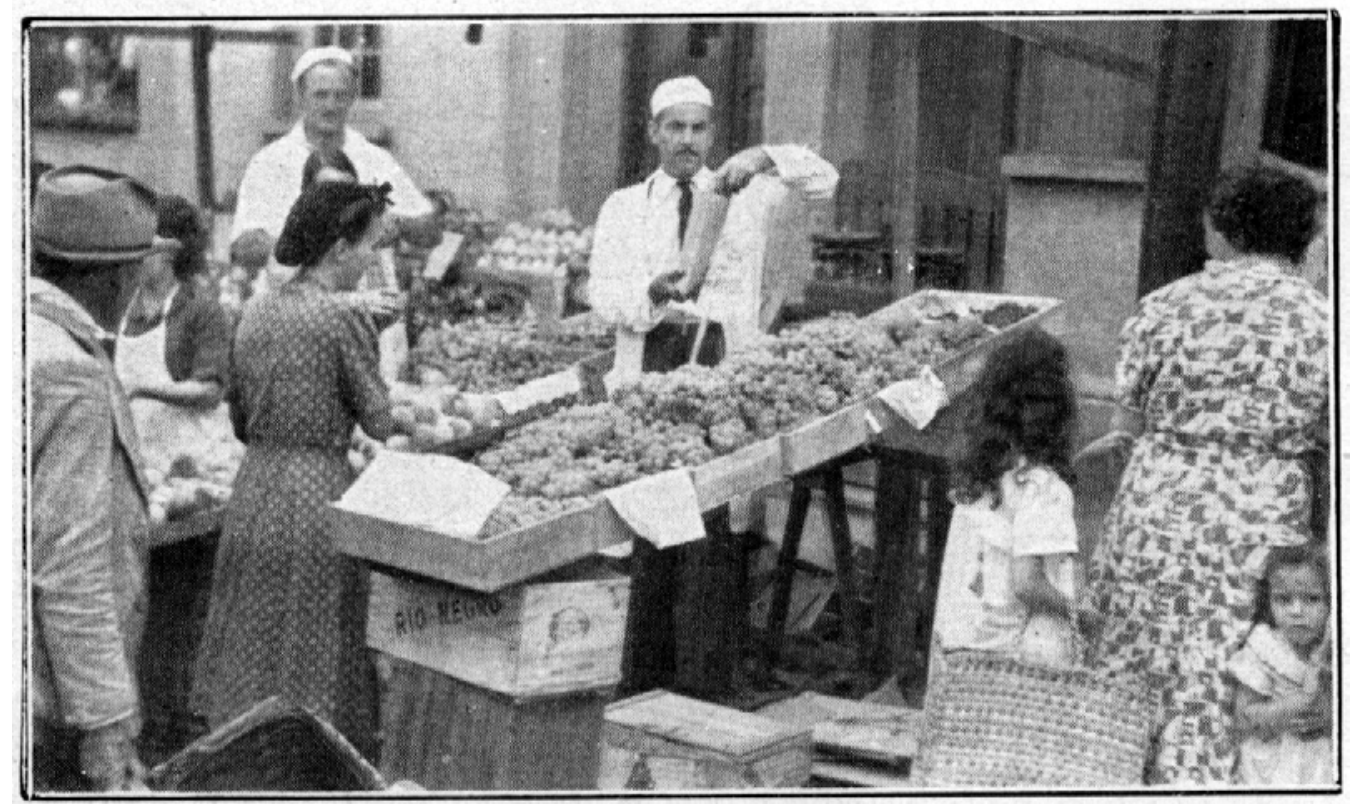

Fig. 12 - Banca de um feirante de frutas. (Foto G. Comparini).

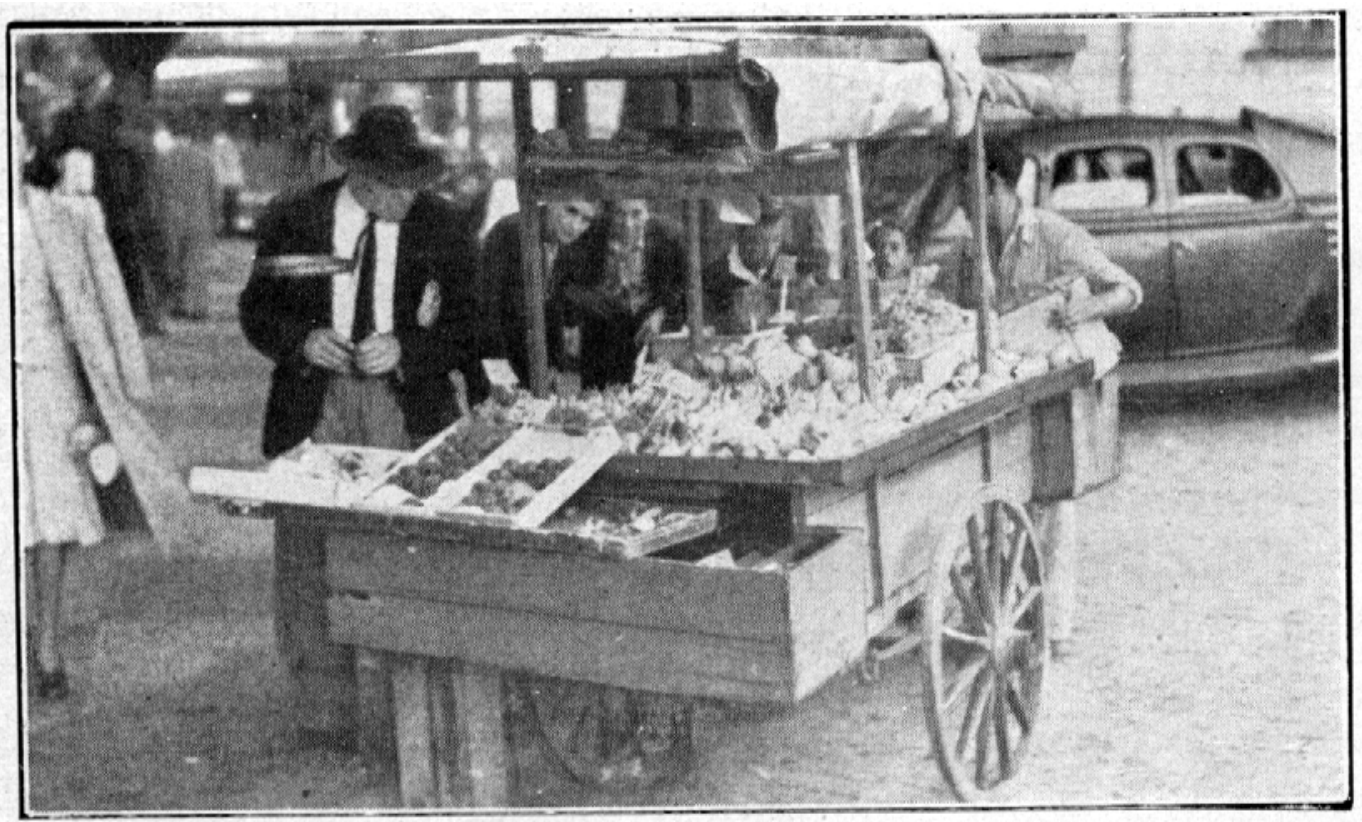

Fig. 13 - Ambulante com estacionamento em ponto central da Cidade. (Foto. G. Comparini). 
Nem sempre é fácil determinar qual dêsses sistemas é o vigorante no comércio de um produto em um mercado, pois, nesse caso, prestam pouco auxílio os dados estatísticos disponíveis. Para elucidar essa questão, somos obrigados a nos valer de conhecimentos teóricos e no conhecimento pessoal das práticas do comércio do produto. E é o que pretendemos fazer ao tratarmos dêste problema.

Como as condições do mercado atacadista são diferentes das do retalhista, vamos estudar separadamente o estabelecimento dos preços para cada um dêles.

\section{Mercado atacadista}

O estudo dos preços de figo e uva no mercado atacadista é de grande importância dentro da pesquisa da comercialização destas duas frutas, pois, como se verá a seguir, os preços dos demais mercados estão, em grande parte, na dependência dos estabelecimentos no atacado.

Já vimos que no comércio de figo e uva se encontram três mercados distintos e que a cada um dêles corresponde uma classe de preços : o do produtor, o do atacado e o do retalho. Mostramos também que essas três classes de preços têm uma certa dependência entre siı, pois o preço de um mercado tem sempre relação com o mercado que o antecede ou com o que lhe segue no canal de distribuição. Daí a necessidade de se saber, para que se possa analisar o mecanismo do estabelecimento dêsses preços, qual dêles é o que reage em primeiro lugar às variações da oferta e da procura, e, pois, qual dêles é que serve de base para o esta. belecimento dos outros dois.

O simples conhecimento de como se processa a comercialização dessas frutas nos indica que tôdas as pessoas envolvidas no comércio de frutas, desde os produtores até os consumidores, são os atacadistas que, por sua posição tôda especial, estão colocados para sentir, mais diretamente e em primeiro lugar, os efeitos tanto da oferta como da procura. Aos atacadistas, devido sua posição central no canal de distribuição, vêm ter diàriamente a soma da produção e a soma das procuras do produto. Por êsse motivo, o mercado atacadista está num contínuo processo de ajustamento entre ofertas e procuras sempre variáveis e 0 resultado dêsse ajustamento é o preço do atacado $\left(^{*}\right)$ que, por sua importância, é geralmente referido como "preço no mercado".

(*) Este pode ser o preço pelo qual o atacadista compra ou pelo qual vende o produto. Em nosso estudo, sempre que nos referimos a êles, trata-se do preço pelo qual o atacadista vende a fruta. 
Podemos dizer, então, que no caso dessas duas frutas, o preço do mercado atacadista é que servirá de base para que seja estabelecido quanto vai ser pago ao produtor e quanto vai ser cobrado do consumidor final. Isso ocorre, não só porque êsse é o preço que melhor reflete as tendências da oferta e procura, mas, também, porque o comércio atacadista tem fôrça, devido à posição central que ocupa no canal de distribuição, para impô-lo como preço-base para os produtores e retalhistas.

Com relação ao sistema em que se estabelecem os preços no atacado, é comum ouvir-se dizer que funciona sob um sistema de monopólio, ou, melhor, sob um regime de combinação de grandes atacadistas, dando em resultado um contrôle dos preços por parte dessas pessoas.

Estudando, porém, êste mercado atacadista, somos levados a acreditar que não há uma combinação tácita entre os negociantes, com o fim de contrôle de preços, mas que a sua situação se assemelha muito à dos mercados que funcionam sob o sistema de competição monopolística, isto é, aquêles em que cada negociante possui monopólio do produto que vende $e_{\text {, a }}$ a mesmo tempo, compete com os monopólios dos demais atacadistas, o que dá como resultado um contrôle parcial da oferta $e$, consequentemente, dos preços, ao contrário de uma combinação entre os negociantes, que resultaria em contrôle total da oferta e dos preços.

A teoria da competição monopolística explica perfeitamente todos os casos de estabelecimento de preço sob condições que não são nem as de competição nem as de monopólio puros. Como esta teoria é relativamente nova e pouco conhecida, e também por que a acreditamos explicativa do que no mercado atacadista de figos e uvas, tentaremos expor, em poucas palavras, sua significação, valendo-nos da argumentação de Chamberlin, que foi o primeiro a explaná-la. (*)

Lembraremos, em primeiro lugar, a diferença entre monopólio e competição puros. $O$ único requisito para haver monopólio puro de um produto, é que um só vendedor controle a oferta total dêsse produto, o que dá como resultado o contrôle sôbre seu preço. De outro lado, para que haja competição pura, é necessário apenas não haver qualquer grau de tal contrôle e isto só se dá quando: $1^{\circ}$ ) existe um grande número de compradores e vendedores, de modo que a influência de qualquer um sôbre a oferta total é desprezível ; $2 .^{\circ}$ ) todos negociam com artigo indêntico e no mesmo mercado. Se atentarmos bem para as condições

(") E. H. Chamberlin. Em "The theory of monopolistic competition", Ath edition, Horward University Press, 1939. th. VII +241 . 
necessárias à existência de competição pura, veremos que enquanto a primeira (grande número de negociantes) pode ser encontrada com certa facilidade em muitos mercados, a segunda já é mais difícil de ser preenchida devido à diferenciação ( $\left.{ }^{*}\right)$ que sempre existe nos produtos negociados. E, sempre que aparece diferenciação, há presença de monopólio, porque desde que um produtor ou negociante diferencia, por pouco que seja, o seu produto dos demais, êle pode controlar a oferta dêsse produto e, pcrtanto, o seu preço, tornando-se assim um monopolista. Quanto maior fôr a diferenciação do produto, com relação a seus mais próximos substitutos, maior é a fôrça do monopólio. Dá a existência de monopólios puros, onde não é possível a substituição de um produto por outro. $\left({ }^{\star *}\right)$ Entretanto, entre os extremos dêsse monopólio puro e da competição pura, situam-se inúmeros casos (os mais numerosos na vida real), em que um produto monopolizado pode ser substituído, com maior ou menor facilidade, por outros também monopolizados. Podemos definir êsse conceito de outra forma, dizendo que cada vendedor tem um monopólio absoluto da quantidade total de seu produto, e, ao mesmo tempo, está sujeito à competição de substitutos mais ou menos imperfeitos. Há, pois, nesse caso, uma mistura de elementos competitivos e monopolísticos, agindo em conjunto. $O$ sistema em que os preços se estabelecem em situações como essa, não é nem o de compe. tição nem o de monopólio puro, mas um outro em que são considerados tanto os elementos de monopólio como os de competição e que foi denominado de "competição monopolística" por E. W. Chamberlin.

Para melhor compreensão do que iremos expor mais adiante, a respeito do mercado atacadista de figos e uvas, vamos dar, de modo resumido, os principais caraterísticos do estabelecimento de preços neste sistema. $\left(^{(\star \star}\right)$

Quando sob competição pura, já dissemos que cada competidor não pode alterar o preço do produto por fôrça de sua oferta ; devido a isso

(") A expressão "diferenciação do produto" tem aqui significação bastante ampla. Ela pode indicar, não s6 mudança na qualidade do próprio artigo, ou mudança de embalagem, como ainda, diferenças no sistema de negccił-lo; prestação de um serviço mais adequado; uma localização mais apropriada do negociante; ou melhor reputação sôbre seu modo de negociar. Basta que, por qualquer um dêstes motivos, - comprador prefira adquirir o produto de um negociante em vez do de outros, imaginando que está obtendo vantagem, para diferençar o produto dêsse negociante dos demais.

("*) Essa afirmação é feita em teoria, pois, como qualquer bem ou serviço pode ser substituído por outros com maior ou menor facilidade não se admite a existência de monopólios puros na vida real. (Ver, por exemplo, Richard T. Ely-Monopolies and Trusts, citado por Chamberlin.

("*) Para tornar mais compreensível esta nossa exposição, apresentamos na página seguinte dois gráficos elucidativos sôbre o estabelecimento de preços. 


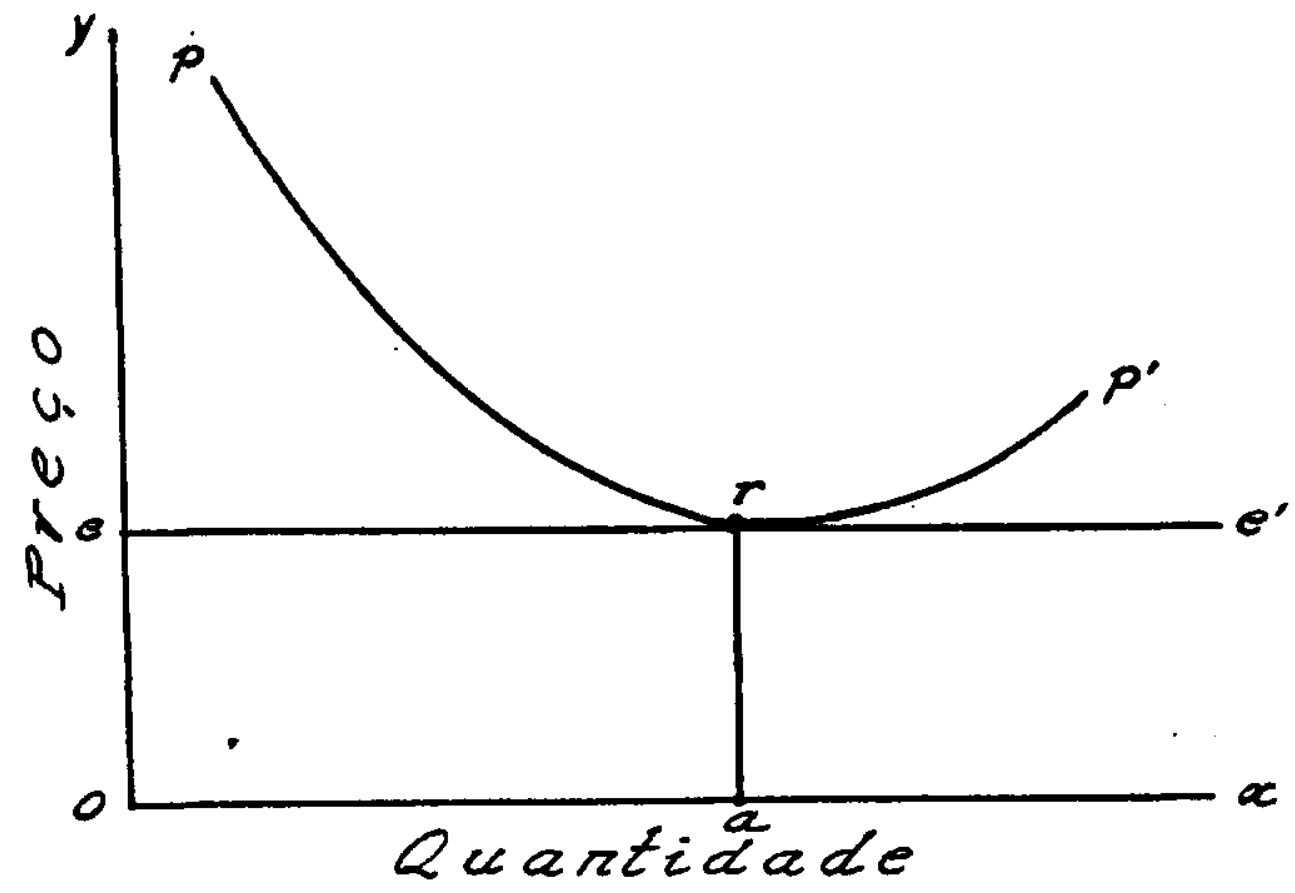

\section{A - Competição pura}

$\mathrm{pp}^{\prime}$ = curva de custo de operação do produtor marginal

$\theta e^{\prime}=$ " " procura do produtor marginal

$\mathbf{r}=$ ponto de menor custo

ar $=$ preço

oa $=$ quantidade produzida

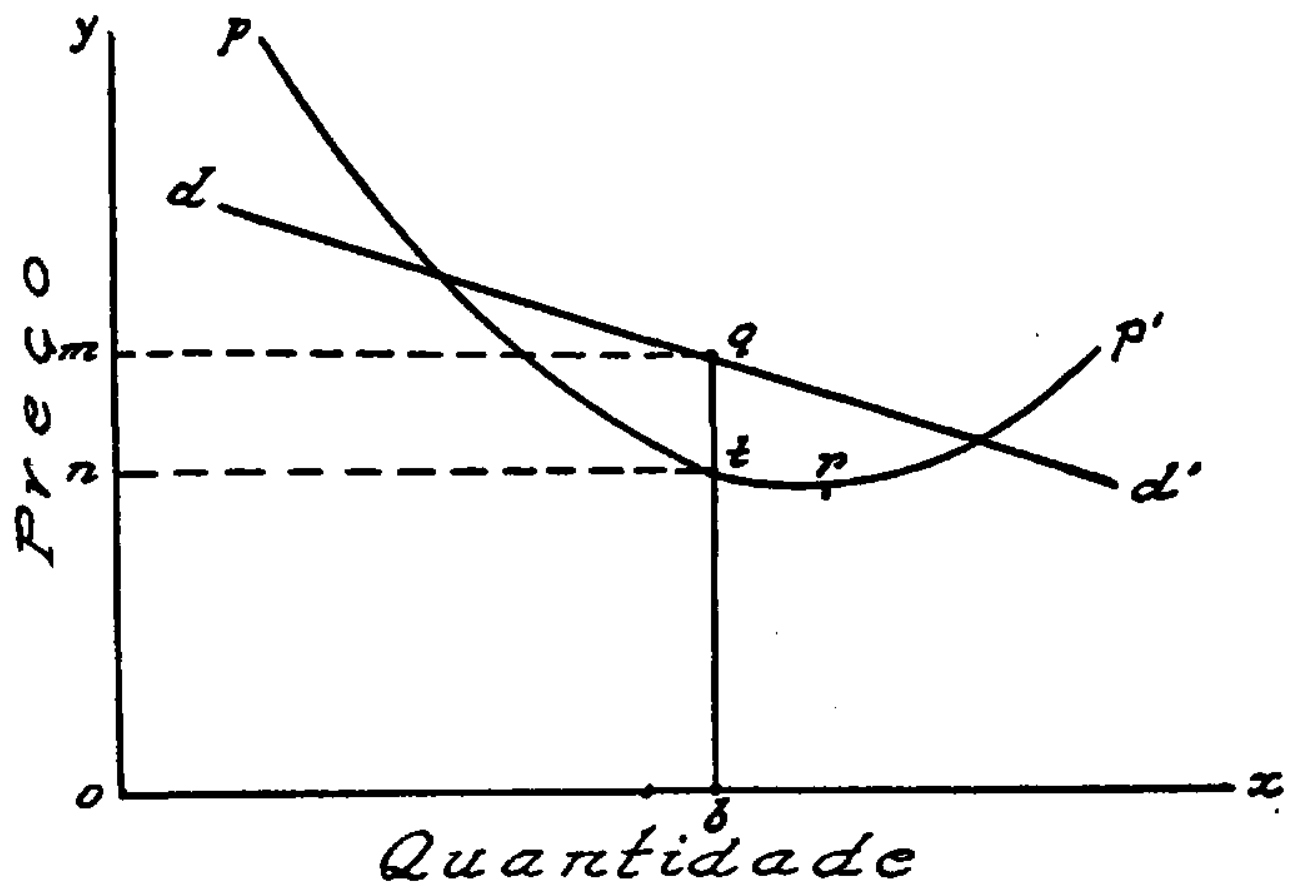

$B$ - Competição monopolística

$\mathrm{pp}^{\prime}$ = curva de custo de um produtor de artigo diferençado (competidor monopolista)

dd' = curva de procura do produtor de artigo diferençado (competidor monopolista)

$r=$ ponto de menor custo

$\mathrm{bq}=$ preço (que proporciona maior lucro)

$\mathrm{ob}=$ quantidade produzida

mqtn = área de lucro máximo (lucro de monopblio). 
a curva de procura do artigo de cada competidor é uma horizontal que passa pela interseção das curvas da oferta e da procura totais dêsse artigo, ou seja, pelo preço corrente do mercado. Quando, porém, existe qualquer grau de monopólio de um produto, a curva de procura dêsse produto é inclinada, o que quer dizer que diferentes quantidades serão compradas por diferentes preços, motivo por que o monopolista pode escolher o preço que lhe traga o maior lucro, variando a quantidade que coloca no mercado. Ainda mais, sob competição pura, o preço de equilíbrio cobre exatamente o custo de produção do produtor marginal (*), isto é, a curva de procura dêste, além de horizontal, é tangente ao.ponto de menor custo da sua curva de custo de produção. Sob competição monopolística, ao contrário, apesar de a curva da procura do monopolista poder ser tangente à sua curva do custo (o que significa que o preço cobre exatamente o custo), ela nunca é tangente ao ponto de menor custo e, sim, num ponto qualquer antes que aquêle seja atingido; isto se dá por contingência da própria inclinaçãoda curva da procura do monopolista. Em outros casos, a curva da procura do monopolista se sobrepõe no todo ou em parte à curva do custo (aparecendo como secante a esta) o que significa que o monopolista está obtendo lucros superiores ao normal.

Principalmente devido a essas duas diferenças (quanto à horizontalidade e ponto de tangência), o preço sob condições de competição monopolística é sempre mais alto, a escala de produção é sempre menor $e$, consequentemente, o número de competidores é maior do que sob condições de competição pura. $\left.{ }^{* *}\right)$

A simples comparação entre as condições atuais do mercado atacadista de figos e uvas e as que se apresentam em um mercado sob competição monopolística, já evidenciam a semelhança existente entre ambas. Acreditamos que duas condições prevalecentes nesse comércio e que podem ser fàcilmente verificadas, já fornecem suficiente evidência de que êle funciona sob o sistema de competição monopolística. Queremos nos referir ao número de atacadistas e à diferenciação que êstes fazem no produto negociado, como procuraremos pôr em relêvo a seguir.

(") Está inclú́do nesse custo um lucro normal para o negociante.

(*) A existência de um maior número de negociantes no sistema de competição monopolística, parece ser uma incoerência, pois isso deveria impossibilitar a existência de qualquer grau de monopblio, isto é, deveria levar o comércio a uma condição de competição pura. Lembremos, entretanto, que devido à diferenciação do produto, - mercado fica de tal forma subdividido, que nenhum negociante consegue produzir na escala mais eficiente $\theta$, assim, para atender d̀ procura total do artigo, existe maior número de negociantes, cada qual com pequena escala de produção. 
$\bigcirc$ primeiro fato a ser pôsto em evidência, é que o número de atacadistas que negociam com figos e uvas, é pequeno em relação ao de produtores e retalhistas, que se situam de ambos os lados dos atacadistas na comercialização. Só esta circunstância, aliada ao fato de ocuparem os atacadistas uma posição central na comercialização, já lhes confere uma fôrça monopólica, pois a oferta ou a procura de cada um dêles não pode ser considerada desprezível em relação às dos demais e, assim, elas afetam sensivelmente a oferta e procura totais dessas frutas e, consequentemente, o preço que se estabelece no mercado. E já vimos que para haver competição pura (único sistema oposto a qualquer grau de monocólio) é condição essencial, que a oferta ou procura de um, não afete de nenhum modo o preço estabelecido no mercado. Ora, no comércio de figo e uva, para venderem sua fruta, as centenas de produtores só podem escolher entre duas ou três dezenas de atacadistas, do mesmo modo que milhares de retalhistas, só a êstes poucos atacadistas podem recorrer para refazerem seus estoques. Êste fato coloca cada atacadista em posição favorável para influenciar sensìvelmente o mercado, isto é, os preços aí estabelecidos por fôrça de sua procura ou oferta individual.

Outro fato muito significativo da atuação dos atacadistas como competidores monopolísticos é a diferenciação que cada um dêles faz no produto que tem à venda.

Acabamos de ver que, devido ao pequeno número (em relação aos produtores e retalhistas) e à posição central que ocupam na comercialização, os atacadistas ficam investidos de fôrça monopólica. Dois casos poderiam, então, ocorrer nesse mercado: ou o estabelecimento de um monocólio puro (os atacadistas fariam uma combinação entre si com o fim de controlar os preços) ou a existência de competição monopolística. Desde que há possibilidade de diferençar o produto negociado, ocorre, naturalmente, a competição monopolística. Êste caso de competição monopolística é o que Chamberlin denominou de "olipólio mais diferenciação", isto é, o número de competidores é pequeno e a ação de um afeta a posição dos demais e, além disso, há diferenciação no produto negociado por cada um dêleș.

A diferenciação feita pelos atacadistas é tão patente, que se poderia, mesmo, caraterizar cada um dêles, pelo modo como conduz suas operações de compra e venda de figos e uvas. Uma explanação mais detalhada desta diferenciação dará uma melhor idéia de como ela se estabelece e quais suas consequências. 
Preliminarmente, convém esclarecer que, devido sua posição central na comercialização, os atacadistas precisam diferençar o produto, tanto na compra aos produtores, como na venda aos retalhistas, isto é, êles são monopolistas na compra e na venda da fruta ("). $A$ diferenciação na compra é feita com o fim de o atacadista se assegurar da posse de uma quantidade tal de fruta, que lhe seja a mais conveniente, tendo em vista a curva de procura de seu produto. A diferenciação na venda, por sua vez, é feita com duas finalidades: em $1 .^{\circ}$ lugar, a fim de 0 atacadista, tendo em vista as curvas da procura dos produtos de seus mais próximos competidores, poder colocar no mercado justamente aquela quantidade que lhe trará maior lucro, ou melhor, a fim de "manter sua posição" ; em 2. ' lugar, com o fim de tentar melhorar (tornar mais inelástica) a curva de procura de seu produto.

A diferenciação na compra é feita pelo atacadista, através de variações nos serviços que presta aos produtores. Não só os serviços são diferentes, como ainda são várias as formas sob as quais os mesmos se apresentam. Podemos citar, ràpidamente, os principais serviços que, por suas variações, diferenciam o produto: um dêles é o financiamento que, na entre-safra, muitos atacadistas fazem aos produtores sob as mais diversas formas ; outro, é a compra que fazem para os produtores, de certos materiais de que êstes necessitam, como inseticidas, instrumentos de trabalho, etc. ; finalmente, talvez a mais importante diferenciação de serviço seja feita pelo sistema de negócio usado: se a "preço fixado" ou à consignação e, neste último caso, pela variada forma de cobrar a comissão: enquanto uns cobram uma percentagem fixa, outros cobram uma quantia variável, alguns englobam na comissão as despesas havidas, ao passo que outros as descontam d̀-parte, etc. $\left({ }^{\star *}\right)$.

Pela prestação dêsses serviços, os atacadistas estão, de certo modo, "prendendo" a si êsses produtores; e cada atacadista pode aumentar ou diminuir a quantidade que negociará, conforme queira, prestando ou deixando de prestar êsses serviços. Isto quer dizer que, tendo em vista a curva de procura de seu produto, o atacadista poderá escolher a quantidade que mais lhe convém comprar, a fim de que seu lucro seja omaior possível. A diferença entre êsse atacadista e um monopolista puro, é que, enquanto a curva de procura de monopolista puro é única e independente da de qualquer outro produto, a de um atacadista de figos e uvas (competição monopolística) depende, quanto à elasticidade e po-

(") O monopólio de compradores, 6 mais corretamente denominado "monopsonia".

(**) Ver o capítulo referente à comercialização pelo produtor. 
sição, das curvas de procura de seus mais próximos substitutos (a uva e figo negociados por outros atacadistas). Por êsse motivo, o contrôle da oferta de um artigo, é menor sob competição monopolística do que sob monopólio puro, dependendo o grau de contrôle, naturalmente, do número de monocólios que estão competindo entre si. $\grave{A}$ medida que aparece maior número de competidores monopolistas de um artigo, a curva de procura de cada um tende a baixar e, mesmo, a girar para a esquerda (tornando-se mais elástica), aproximando-se da horizontalidade da curva na competição pura. (*)

A diferenciação baseada em variações na qualidade da fruta também ocorre e, neste caso, ela se apresenta de maior valor na venda do produto pelo atacadista. A uva procedente de Louveira, por exemplo, pelo sabor mais agradável, é preferida pela maioria dos consumidores $e$ isso a distingue da uva de outras procedências (Valinhos, Rocinha), permitindo aos que com ela negociam o estabelecimento de um preço diferente do das demais ; também a fruta de certos produtores se diferencia da de outros, não só pela sua melhor qualidade, como pelo cuidado com que são classificadas e embaladas; os atacadistas que negociam com êstes produtores, são verdadeiros monopolistas da sua fruta, porque estão negociando aquela qualidade que é a única no mercado. O preço para cada um dêsses produtos diferenciados se estabelecerá de acôrdo com o valor atribuído a essa diferenciação; isso porque cada um dêsses produtos tem uma freguesia certa que o comprará, relacionando, só em parte, seu preço, com o de seus mais próximos substitutos.

No caso de figo e uva, entretanto, a diferenciação na venda é de pequena importância, devido às facilidades existentes para a substituição, sem grandes diferenças, de uma qualidade de fruta por outra, como também, e principalmente, pela facilidade atual de venda motivada pelo aumento contínuo da procura dêsse produto.

Por êsse motivo, a venda do produto, que no regime de competição monopolística é uma das atividades que exigem os maiores esforços do negociante, com o fim de manter ou de aumentar até certo ponto, a clientela do produto que êle deferencia, é para os atacadistas de figo e uva, um problema quase inexistente, pois a venda do produto de todos os atacadistas é fácil e seguro $\left(^{* *}\right)$. Daí, os atacadistas não precisarem lançar

(") Para que isso aconteça é necessário, entretanto, (como veremos adiante), que diminuam ao mesmo tempo as possibilidades de diferenciação do produto, sem o que haverá cada vez maior subdivisão do mercado.

(*) Devido a essa pequena diferenciação na venda, a competição monopolística quase se reduz aqui a um caso de olicopólio, isto é: pequeno número de vendedores de um artigo idêntico (não diferençado) e em que a ação de um afeta a posição dos demais. 
mão dos recursos habituais que conduzem à diferenciação do produto na venda, isto é, anúncios, concessões aos compradores, abatimento de preços aos fregueses, etc.; ao contrário, o que se observa é a quase nenhuma facilidade de pagamento concedida aos retalhistas (quando a venda é a prazo, geralmente êste não é maior que uma semana), a inexistência do conhecido "pechinchar", a não prestação de pequenos serviços como a entrega da mercadoria no estabelecimento do retalhista e a pequena frequência de abatimento de preço aos fregueses antigos.

Ao contrário do que se poderia esperar, a variação de preço entre os atacadistas é pequena, isto é, a tendência é para que o preço seja mais ou menos o mesmo para todos os atacadistas no mesmo dia. Parece haver certa contradição entre essa pequena variação no preço de venda e a existência de competição monopolística nesse mercado; na realidade, essa contradição não existe, pois, mesmo com a pequena diferenciação que há na venda (e de fato existe alguma, como já dissemos), isso implica em diferentes preços : o negociante pode, sob o preço prevalecente no mercado, diferençar seu produto na qualidade, serviços, etc., de modo a induzir o consumidor a comprar de si uma quantidade maior que dos outros negociantes ou, ao menos, justamente aquela quantidade que lhe trará maior lucro, sem recorrer a uma baixa no preço.

Acreditamos que sòmente a concorrência dessas duas condições (pequeno número de atacadistas e diferenciação no produto) já se mostra bastante significativa, evidenciando nesse comércio a existência de competição monopolística, pois, como já vimos, essas são condições que lhe são próprias.

Torna-se claro, portanto, que esta situação do mercado atacadista é uma das causas do alto preço. Vimos que a oferta maior que a procura e a queda do valor aquisitivo interno da moeda são as principais responsáveis pela elevação no preço dessas frutas; em situações como essa, a elevação seria mesmo de se esperar, ainda que o mercado funcionasse sob competição pura. Entretanto, por se achar o mercado em condições de competição monopolística, a situação se agrava, isto é, os preços se estabelecem em níveis ainda mais altos, pois já vimos que, sob condições de monopólio, apesar de o negociante não poder estabelecer o preço em qualquer nível a seu prazer, êle pode, entretanto, conhecendo a curva de procura do produto, regular a quantidade a ser posta no mercado, de forma que o preço resultante seja o que lhe proporcione o maior lucro, e êsse preço, é sempre mais elevado do que se vigorasse o regime de competição pura. 
Da mesma forma, a competição monopolística é que possibilita a cobrança de uma alta margem por parte dos atacadistas, de modo que os produtores quase não se beneficiam com uma elevação de preços no atacado; já vimos que, sob tal sistema, a curva de procura do monopolista pode sobrepor-se à do seu custo (aumenta a margem do negociante) e isso significa lucro de monopólio.

Enquanto houver condições que possibilitem a existência da competição monopolística não será possível diminuir a margem até o nível atingido sob competição pura; pode-se, entretanto, reduzí-la, ou pelo aumento do grau de competição entre os monopólios existentes ou pelo aumento do número de monopólios competidores. É claro que essas possibilidades estão na dependência das condições do produto negociado e do seu mercado.

No caso presente, é possível aumentar a competição entre os monopólios atuais, lançando-se mão de certos recursos como a padronização das frutas, a regulamentação dos sistemas de negócios, etc., isto é, tentando reduzir ao mínimo, as possibilidades de diferenciação do produto, que é a principal responsável pela existência de competição monopolística. Essa diminuição de diferenciação, tende a tornar as curvas de procura dos monopolistas mais elásticas, o que resultará em diminuição nos preços.

De outro lado, o aumento do número de monopólios tende a baixar as curvas de procura dos monopolistas até, se possível, o ponto em que essas curvas sejam tangentes à do custo, isto é, que as margens sejam as mínimas possíveis, sendo eliminados os lucros de monopólio. No caso destas frutas pode-se dizer que existem possibilidades de diminuir as margens dos atacadistas pela maior liberdade de entrada de novos negociantes no comércio atacadista, de modo a estabelecer maior concorrência entre êles. Esta medida, entretanto, não se apresenta tão fácil de ser conseguida, devido às restrições naturais e artificiais existentes. Assim, essa profissão exige certos conhecimentos especializados, só adquiríveis após alguns anos de prática, e isso limita a entrada de novas pessoas nesse comércio, mesmo sob a tentação dos lucros atuais de alguns atacadistas. Outra restrição é que o negócio exige a utilização de certo capital desde seu início. Finalmente, uma das principais restrições é ser o Mercado da Capital um recinto fechado, não existindo, comumente, bancas vagas d̀ disposição de novos atacadistas; devido a isso, novos negociantes só poderão entrar no negócio, pagando altos preços (luvas) aos atuais arrendatários das bancas, o que não é muito animador para êles, 
pois o negócio ficaria sobrecarregado, de início, com um maior investimento de capital. Pode-se, entretanto, perguntar, por que os demais negociantes de frutas e hortaliças que já estão estabelecidos no Mercado não negociam também com figo e uva, a fim de compartilharem dos altos lucros que alguns obtêm nesse ramo ? Além das razões expostas acima (especialização e capital), êsses comerciantes, provàvelmente, assim não procedem porque estão obtendo com os outros produtos lucros idênticos ou maiores que os que obteriam com essas duas frutas.

Se fôsse mais fácil e livre a entrada de novos negociantes, apesar de cada um ainda poder ser considerado um monopolista para o produto que negocia, a competição entre êles seria maior, e, nesse caso, a tendência seria para menores preços e menores margens, isto é, seriam beneficiados os consumidores e produtores, respectivamente. Esta medida, porém, só se mostraria eficaz se fôsse acompanhada daquelas outras de que falamos há pouco para reduzir as possibilidades de diferenciação.

\section{Mercado retalhista}

Como dissemos anteriormente, o estudo das causas do alto preço deve incluir também a análise das condições do mercado retalhista, pois estas são diferentes das encontradas no atacado; dêsse modo, o sistema em que se estabelecem os. preços no retalho pode permitir que novos fatôres venham concorrer para a maior elevação dos preços.

Antes de verificarmos essas condições particulares do mercado retalhista que afetam o estabelecimento dos preços, convém mostrar como o retalhista determina seu preço de venda. Êsse modo é relativamente simples: ao preço do atacado, êle acresce uma certa "margem" que cubra o custo de sua comercialização (as despesas com serviços que êle é obrigado a prestar, para colocar a fruta ao alcance do consumidor) e que lhe proporcione, ainda, um certo lucro $\left(^{*}\right)$.

Essa margem, por motivos que veremos lozo mais, não é uniforme para todos retalhistas, não só porque as condições do mercado (a procura, por exemplo) não são iguais para todos êles, como também, porque as próprias condições de comércio de cada retalhista (espécie de serviços prestados, localização, volume de negócios, etc.), diferem de um para outro. Assim, com o preço de atacado de $\mathrm{Cr} \$ 24,00$, para a caixa de uva, encontramos fruteiros que cobram $\operatorname{Cr} \$ 5,00 \circ \mathrm{Kg}$, outros $\operatorname{Cr} \$$ 4,50 e outros ainda $\operatorname{Cr} \$ 4,00$; isto é, apesar de o preço de compra

(*) Empregamos aqui o têrmo-lucro-em seu sentido mais comum, englobando: o ordenado do retalhista, juros sôbre o capital fixo e de custeio e a parte correspondente à cobertura do risco (lucro puro). 
ser o mesmo, as margens dos 3 retalhistas são, respectivamente, $\operatorname{Cr} \$$ 2,00, $\mathrm{Cr} \$ 1,50$ e $\mathrm{Cr} \$ 1,00 \mathrm{em}$ cada $\mathrm{Kg}$ vendido.

O que se deveria esperar, todavia, de um mercado como o retalhista, no qual intervém um tão grande número de negociantes, é que a competição fôsse tão acentuada que resultasse na determinação de margens mínimas e uniformes ou, melhor, de preços uniformes em todo êsse mercado.

A razão por que não se obtém êsse resultado é que o mercado retalhista, em maior grau que o atacadista, funciona sob o regime de com. petição monopolística.

Já tratamos extensamente dêste sistema no mercado atacadista, motivo por que não vamos repizar o assunto. Iremos, agora, sòmente, mostrar como, pela possibilidade de diferenciação do produto que existe no mercado retalhista $\left({ }^{*}\right)$, prevalece nêle o regime de competição monopolística, e apontar ainda quais as consequências econômicas que disso resultam.

Os serviços peculiares ao comércio a retalho são em tão grande número e se apresentam tão variáveis, que oferecem ampla oportunidade aos negociantes para diferenciarem seu produto de tal modo, que isolam em certo grau, seu mercado do de seus mais próximos competidores (o que os torna moniopolistas, portanto) $\left(^{* \star}\right)$, possibilitando a obtenção de maior lucro, por uma variação no preço, ou por variação na procura de seu produto, ou, ainda, usando êstes dois recursos ao mesmo tempo.

Como veremos a seguir, a diferenciação do produto é feita no mercado retalhista, pela variação em duas ordens de serviços: uma, são aquêles serviços que se podem medir diretamente em têrmos de custo, tais como a embalagem, a localização, os transportes, etc. ; outra se refere a serviços muito importantes no comércio retalhista, os quais são difíceis de serem avaliados em têrmos de dinheiro, como, por exemplo, a habilidade na disposição de mostruário de frutas, a delicadeza no trato com o público, o cuidado especial na embalagem, renome quanto à honestidade nos negócios, etc. $\left(^{* * *}\right)$

(") Ver nota (*) d̀ página 509

(**) Lembramos que para haver competição pura, é necessário, não so que haja um grande número de compradores e vendedores, como, também, que todos negociem com artigo idêntico e no mesmo mercado.

(**) Êstes últimos serviços têm grande importância no mercado retalhista e tal ê sua natureza que é comum dizer-se que : no mercado retalhista, além do produto, pròpriamente dito, o consumidor está comprando também certos serviços, como embalagem, entrega, uma localização que lhe é conveniente, um tratamento polido por parte do negociante, crédito, etc. Clark, F. E. and Wild, L. D. H. - Em Marketing Agricultural Products in the United States - The Macmillan Company - 1933 - pg. - 500 XIV - 672. 
Quando se trata de variações do primeiro caso, não só a curva de procura do retalhista é alterada, como, também, a do próprio custo de operação; dêsse modo, o retalhista precisa diferençar os serviços de tal forma que o ajustamento entre as duas curvas seja o que lhe proporcione o maior lucro.

Já quando a diferenciação é feita em serviços que não podem ser medidos em têrmos de custo, só a curva da procura é alterada, permanecendo a mesma (dentro de certos limites) a curva de custo, de modo que o problema do ajustamento das duas curvas com o fim de obter maior lucro é mais simples.

Geralmente, ao procurar obter o máximo de lucro, o retalhista não adota rígidamente uma dessas práticas, mas, sim, segue esta ou aquela, segundo as circunstâncias do momento. $\mathrm{Na}$ descrição que faremos a seguir, das principais modalidades de diferenciação usadas no retalho de frutas, procuraremos mostrar como cada uma delas afeta as curvas de custo e de procura e qual o problema de ajustamento que se apresenta ao negociante. Entretanto, devemos deixar claro que, ao contrário do que se poderia depreender de nossa análise, na maioria das vêzes, essa diferenciação e o consequente ajustamento se processam num lento evoluir e de um modo quase inconciente para os negociantes.

Vejamos, então, como se processam algumas formas de diferenciação do produto dos retalhistas de figo e uva, em São Paulo (").

A própria divisão dos retalhistas em classes bem distintas (frutarias, feirantes etc.), já é por si mesma, uma resultante dessa diferenciação. De fato, essas classes se diferenciam entre si, pela variação nos serviços que prestam aos consumidores, o que possibilita a cada uma delas formar uma linha própria de fregueses (isto é, que cada uma tenha uma curva de procura própria), de modo que os retalhistas podem determinar, dentro de certos limites, o preçó que lhes proporcione o maior lucro e isso significa preço de monopólio. Mesmo que, ocasionalmente, o preço seja idêntico ao de outros retalhistas, a diferenciação pode ser de tal forma que do ajustamento entre as curvas de procura e de custo do seu produto resulta a obtenção de maior lucro. Podemos ilustrar o caso com o exemplo de uma quitanda ou ambulante de bairro: a maior parte da freguesia dêstes retalhistas, dêles compra sem cogitar se existe mercadoria melhor na cidade ou a um preço mais barato; êsses fregueses não costumam ou não têm tempo para correr diversos estabelecimentos

(") Estas formas de difereneiação, aliás, são comuns ao comércio de gêneros alimentícios em geral. 
do gênero e fazer comparações sôbre qualidade e preços ; dêsse modo, a freguesia está "presa", em certo grau, ao retalhista, pela espécie de serviço que êste lhe presta (e que pode ser : no caso de a quitanda estar localizada em ponto conveniente ao consumidor, ou servílo em sua própria casa no caso do ambulante; ou abrir-lhe um crédito mensal, em ambos os casos). Baseados nesse monopólio, é que certos ambulantes e quitandeiros vendem fruta de qualidade inferior por preço idêntico ao de melhores qualidades, sem que os compradores percebam a diferença e deixem de ser seus fregueses.

Da mesma forma, um fruteiro estabelecido em bairro rico, por ter seu produto uma curva de procura própria (melhor situada), pode estabelecer um preço mais alto que outro de bairro mais modesto e, assim, aumentar seu lucro, apesar de terem os dois déspesas mais ou menos iguais (portanto, curvas de custo quase iguais) e venderem fruta da mesma qualidade. É o que também se passa com os feirantes que estabelecem diferentes preços conforme a localização da feira, se em bairro rico ou pobre (") ; neste caso, porém, sem que haja nenhuma diferença no custo, (pois êste é o mesmo para as feiras de qualquer bairro), mas usando o feirante, ùnicamente, sua fôrça monopólica.

Muitos outros recursos empregam os retalhistas para obterem maior lucro, ùnicamente por uma diferenciação do produto que só altere a curva de procura, sem modificação sensível na do custo. Um dêles, é anunciar sua fruta como sendo de determinada procedência (determinada localidade, ou de certo produtor); com isso, aumentam a procura de seu produto, pois atraem fregueses que sabem ser aquela uma produção de melhor qualidade; em muitos casos, êstes frejueses estão mesm postos a pagar um preço um pouco mais elevado por essa fruta.

Outro modo de diferenciação de serviços, "com fito de obter o máximo de lucro, é dar ao estabelecimento um certo caráter de luxo, em local espaçoso, com móveis caros, muitos empregados, iluminação especial, etc.; tudo isso aumenta o custo de operação, mas, ao mesmo tempo, atrai certa classe de consumidores exigentes que fazem questão de comprar em tais estabelecimentos mais "finos"; nesse caso, o retalhista pode estabelecer (e geralmente o faz) um preço mais elevado que seus competidores vizinhos e sua freguesia ainda continuará a lhe comprar a fruta sem cogitar de fazer comparação de preços, ou, então, por achar

(*) Esse fato é comprovado na estatística de preços das Feiras Livres de São Paulo. levantadá pela Subdivisão de Documentação Histórica e Estatísticas Municipais, da Prefeitura de São Paulo e que tivemos ocasião de compulsar. 
que essa elevação de preço é compensada pela prestação daqueles serviços e está concorde com o "caráter" do estabelecimento.

Muitas vêzes o retalhista não precisa, mesmo, diferençar quase os serviços para obter o máximo de lucro, bastando estabelecer um preço mais alto, com o que atrairá uma numerosa freguesia, pois grande parte dos consumidores é incapaz de distinguir a qualidade da fruta, a não ser relacionando-a ao preço: acreditam que quanto maior o preço, melhor é a qualidade. Por isso alguns estabelecimentos costumam ter sempre uma certa quantidade de fruta marcada com preço mais alto (apesar de ser da mesma qualidade que as demais) para servir êsses fregueses que fazem questão de comprar o artigo mais caro, acreditando que estão comprando o melhor. O retalhista, então, obtém maiores lucros, não só devido à elevação dos preços, como pelo aumento de procura.

A resultante econômica dessa grande possibilidade de diferenciação que existe no mercado retalhista é que isso conduz a uma grande subdivisão do mercado, isto é, pode-se dizer que cada retalhista oferece à venda um "produto" diferente dos demais, de modo que seu mercado é separado, em certo grau do de seus colegas. Uma consequência desta grande subdivisão é a chamada "over capacity", quase crônica nesse ramo de negócios, isto é, um grande número de estabelecimentos, além do limite econômico.

A explicação dêsse fato já foi dada antes, quando falamos dos caraterísticos de um mercado em regime de competição monopolística e pode ser resumida aqui : diferençando o produto, com ou sem aumento de preço, os retalhistas dividem de tal forma o mercado que nenhum dêles pode trabalhar na escala de vendas mais eficiente, isto é, aquela determinada pelo ponto de menor custo da sua curva de custo de produção: - volume de negócios dêsses retalhistas é sempre menor do que aquêle que se obteria sob competição pura. Dêsse modo, para atender à procura total dessas frutas, existe maior número de retalhistas (já que o volume de vendas de cada um é menor) do que se prevalecesse nesse negócio a competição pura. $\left(^{*}\right)$

Neste último sistema, não havendo diferenciação do produto, o volume de negócios de cada um seria maior (pois cada um seria obrigado, pela competição, a produzir em escala determinada pelo ponto de menor

(*) O estabelecimento dêsse grande número de negócios tem sido facilitado ùltimamente pelas atuais condições de inflação; a facilidade de crédito que ocorre nessas ocasiōes, aliada às perspectivas de grandes lucros, tem animado o estabelecimento de um grande número de novos retalhistas de frutas, principalmente no centro da cidade. 
custo), sendo expulsos do negócio os retalhistas menos eficientes e diminuindo, pois, seu número.

Outra consequência da competição monopolística nesse mercado, e de não menor importância, é que o preço estabelecido, devido à inclinação da curva de procura do produto, é sempre mais alto do que se prevalecesse a competição pura, mesmo que o grau de competição existente seja tão acentuado que mantenha no mínimo o lucro dos retalhistas; êste resultado também já foi amplamente explanado anteriormente e por isso não vamos repetir a argumentação.

Infelizmente, existem poucas possibilidades de alterar esssa situação no mercado retalhista, não só dos produtos de que estamos tratando, como para o de quaisquer outros. Basta considerar a dificuldade em suprimir as variações dos fatôres que possibilitam a diferenciação no produto neste mercado: por maior que seja a padronização da fruta, a uniformização dos sistemas de negócios, a difusão de prȩ̧os entre os consumidores, sempre restarão certos serviços suscetíveis de variação e de que lançarão mão, ou os retalhistas ou os próprios c snsumidores, para diferençar o produto vendido. Tais são, por exemplo, a variação no modo de tratar os fregueses, a arrumação mais atrativa do estande de frutas, a concessão de crédito, etc. Mesmo que não houvesse variação nesses fatôres, um outro, só êle, seria suficiente para possibilitar a diferenciação; queremos nos referir à localização do retalhista; êste fator, por sua própria natureza, "prende" de tal modo o consumidor a certo estabelecimento, que possibilita a êste retalhista separar, em certo grau, o seu mercado, do de outros retalhistas, com tôdas as consequências já apontadas atrás.

\section{VARIAÇÃO DE PREÇOS}

Apesar de, nos dois capítulos anteriores, havermos examinado as causas das variações de preços de figo e uva, deixamos de lado, a fim de não introduzirmos maiores complicações na exposição, a descrição de certos tipos de variações que ocorrem nos preços dessas duas frutas, principalmente no retalho; ainda que as causas dessas variações possam ser encontradas entre as que acabamos de examinar, achamos que essa descrição ficaria melhor situada em um título à-parte, como fazemos agora. 


\section{Variações de preços com as unidades de venda}

A determinação de preços diversos conforme a unidade de venda, é uma prática comum no mercado retalhista. Com relação ao figo, não é raro observar-se, por exemplo, que, se numa banca, uma gaveta com 36 frutos está com o preço marcado a $\mathrm{Cr} \$ 8,00$, a dúzia é vendida a $\mathrm{Cr} \$$ 3,50 e frutos avulsos a $\mathrm{Cr} \$$. 0,30 cada um; isso significa que aquela gaveta será vendida por 3 preços diferentes $(\mathrm{Cr} \$ 8,00, \mathrm{Cr} \$ 10,50$ e $\mathrm{Cr} \$ 10,80$ ) conforme seja a unidade de venda: gaveta, dúzia ou fruto avulso, respectivamente.

A proporção que guardam entre si êsses três preços varia muito segundo diversos fatôres: classe do retalhista, o estilo do estabelecimento, a qualidade da fruta, etc. Assim, para certos fruteiros do centro da cidade, que preferem vender só nas maiores unidades como as gavetas, a proporção é maior, de modo que marcam um preço elevado para frutos avulsos ou dúzias, a fim de animar o consumidor a comprar uma gaveta, na crença de que assim está obtendo um abatimento. Outros estabelecimentos adotam êsse mesmo modo de proceder, ùnicamente para conservarem uma freguesia "distinta" que, em geral, só compra nas maiores unidades; com êste fim chegam mesmo a estabelecer a dúzia como unidade mínima de venda. Já com os ambulantes, devido à própria natureza de seu negócio, se dá o caso contrário, pois não oferecem muito vantagem de preço para as compras em unidades maiores que o fruto avulso.

Essa proporção depende também de qualidade da fruta, pois muitas vêzes só a fruta já um pouco "passada" é que certos fruteiros põem à venda em unidades menores que a dúzia e, nesse caso, seu preço unitário se diferencia do das outras unidades.

Com relação à uva, já não existe quase essa variação, pois a unidade comum a qualquer retalhista é o $\mathrm{Kg}$; são raros os retalhistas (ś́ os mais modestos) que vendem em unidades menores, como sejam cachos. Entretanto, nas compras de uma caixa de uva, há sempre um abatimento no preço unitário.

Essa variação de preços conforme a unidade de venda é justificável, em certos casos, pois há uma relação entre a unidade de venda e o risco corrido pelo negociante. Assim, um fruteiro vende uma gaveta de figos por preço unitário mais baixo do que se vendesse em dúzias (isto é, êle se contenta com margem menor) porque, nesse caso, os riscos de deterioração e encalhe são menores. Em geral, numa gaveta de figos 
vendida em frutos avulsos, a perda de alguns frutos é sempre certa, pois os compradores guerem escolher a fruta, apalpam-na sem cuidado e, no fim, sempre sobram alguns frutos imprestáveis.

Devido aos motivos atrás apontados verifica-se que é muito difícil determinar uma proporção entre preços e unidades de venda, pois as condições são diferentes para cada negócio. Na pesquisa que fizemos entre os retalhistas (em pequeno número, motivo porque êstes nossos dados não podem ser tomados como representativos para todo o comércio), encontramos para as frutarias do centro da cidade os aumentos médios de 20 e $40 \%$ sôbre o preço da gaveta, nas vendas de dúzias e frutos avulsos ; para os feirantes, êsses números passaram a 50 e $60 \%$, respectivamente. Êstes aumentos maiores, para os feirantes também têm sua explicação, pois, tendo um curto período diário de venda, é de seu interêsse vender em maiores unidades, a fim de evitar encalhe e, para isso, oferecem vantagens de preço para as compras de gavetas inteiras.

\section{Variação de preço com as variedades}

Diferentes preços são estabelecidos no mesmo dia, para as diversas variedades de uva (*). De um modo geral, a uva da variedade Niagara tem a preferência decidida do público, pois êste está sempre disposto a pagar um pouco mais por ela, quando em confronto com as outras variedades mais comuns. Na relação de preços da safra de 1943/44, que apresentamos nos quadros XXVII e XXVIII vemos que a uva Niagara branca vale, em média, $50 \%$ mais que as uvas pretas (Barbera e Corbina), quando vendidas na mesma época. Dentro da própria Niagara há variação de preços, pois a Niagara rosada chega a valer, em certas ocasiões, $10 \%$ mais que a Niagara branca. Entretanto, quando a quantidade das duas Niagaras no mercado é mais ou menos igual, o preço das duas tende a ser o mesmo. Aliás, acreditamos que essa uniformidade de preços será normal dentro de pouco tempo, quando a produção das duas se tornar igual, o que não se dá no momento. As variedades Golden Queen e Diamante Negro, por enquanto produzidas em pequena escala, alcançam sempre melhores preços que as Niagaras; a principal razão para isso é a pequena produção atual, aliada a uma grande procura por parte dos consumidores (principalmente italianos e sírios) que têm preferência por uvas de tipo europeu como estas, coincidindo essa situação com uma época em que não há quase no mercado fruta estrangeira semelhante.

(*) Esta variação não ocorre com o figo, pois, para esta fruta, não são distinguidas variedades. 


\section{MARGENS E LUCROS DOS INTERMEDIÁRIOS}

Por diversas vêzes, durante o decorrer dêste trabalho, tivemos ocasião de nos referir às margens e lucros dos intermediários, sem, contudo, fazer uma análise mais aprofundada dêsses setores da comercialização. Assim procedemos por acreditar que, só após o conhecimento detalhado de tôda a comercialização, seria vantajoso tratar da questão mais minuciosa e objetivamente, pois só então poderia ser bem avaliada a importância e significação dêsses conceitos.

As margens e lucros dos intermediários são das questões mais controvertidas quando se trata da comercialização de produtos agrícolas, em geral. É verdade que não são fáceis de serem obtidos os dados que elucidariam a questão, não só devido às dificuldades técnicas de seu cálculo, como, também, por serem as fontes de informação pouco acessíveis aos extranhos, motivo por que, raramente, se encontram dados verdadeiros, objetivando as mais variadas afirmações que se fazem sôbre êsses problemas.

Essas dificuldades, como já fizemos notar no início dêste estudo, também as encontramos no decorrer da nossa pesquisa, mas, apesar de os poucos dados obtidos não se prestarem a um estudo completo e definitivo $\left(^{(}\right)$, acreditamos que seja útil a tentativa de análise que com êles faremos, entre outros motivos, por fornecer ilustrações objetivas a certas questões tratadas no texto e porque poderá servir de base a outras que se fizerem no futuro, com dados mais completos.

Observando-se os gráficos I e II, organizados com os preços médios semanais dos 3 mercados, verifica-se que as margens, tanto dos atacadistas como dos retalhistas, não são sempre uniformes, isto é, existem épocas em que elas são maiores, e outras, em que são menores. O mesmo fato pode ser observado nos quadros XX e XXI em que as margens estão expressas em números absolutos (cruzeiros) e relativos (em $\%$ do preço de venda dos atacadistas e retalhistas), respectivamente. Não há nem uma quantia uniforme em cruzeiros, nem uma percentagem fixa, que estabeleça o montante da margem durante tôda a safra. A margem varia

(") As principais limitações dêstes cálculos são quanto à representabilidade da amostra e ao caráter aproximativo dos cálculos de custo, pois : a) - os dados de preços foram fornecidos por pequeno número de fontes $\theta$ com bastante falhas; b) - os dados de despesas fixas dos intermediários foram fornecidos de um modo completo, apenas por um intermediário de cada classe; c) - a repartição das despesas fixas entre os diversos produtos vendidos pelos intermediários, 6 baseada únicamente em nosso conhecimento pessoal dêsse comércio; d) - a repartição das despesas fixas entre figo e uva não é proporcional ao volume de vendas de cada uma dessas frutas. 
sempre com os preços obtidos: de um modo geral, aos maiores preços correspondem maiores margens.

Pode-se também notar que as margens dos atacadistas, são maiores nos negócios com figo do que nos com uva, pois, no $1 .^{\circ}$ caso, a margem gira em redor de $50 \%$ do preço do atacado, ao passo que nos de uva ela se reduz a $25 \%$. Já as margens dos retalhistas são mais ou menos idênticas, tanto nos negócios com uva como nos com figo, ficando ao redor de $50 \%$ do preço do retalho, o que significa que, normalmente, o preço do retalhista é o dôbro do que êle pagou ao atacadista.

A margem do intermediário é, muitas vêzes, errôneamente confundida com lucro, e isso tem sido a origem de muitas interpretações pouco exata sôbre a parte retirada pelos intermediários na comercialização. A margem, como já dissemos, é destinada a cobrir, não só o lucro puro do intermediário (que é o pagamento do risco da emprêsa), mas, ainda, tôdas as despesas da comercialização, como: salários, alugueres, impostos, embalagens, anúncios, transportes, etc., e, também, os juros do capital empatado e um ordenado para o proprietário, quando é êste que dirige o negócio.

Por êsse motivo, o conhecimento da margem por si só, nada diz com certeza, se o custo dos serviços necessários à comercialização é grande ou pequeno, assim como nada informa sôbre se o lucro do intermediário é excessivo ou razoável. Uma alta margem pode ser devida tanto à exigência de serviços caros, como a uma posição privilegiada do negociante, que lhe permita obter um grande lucro. Assim, para que se possa determinar a verdadeira situação dos intermediários a êsse respeito, é necessário que se decomponha a margem em todos seus ítens, para que se possa analisar as partes que correspondem às despesas com serviços, e ao lucro dos intermediários.

Já detalhamos no capítulo referente à comercialização dos atacadistas e retalhistas, as despesas que êsses intermediários têm com os serviços da comercialização; dêsse modo, agora que conhecemos o montante das margens, relativas aos diversos preços da safra, podemos calcular a parte que corresponde ao lucro dos intermediários por unidade de venda.

Aqui, porém, se apresenta uma dificuldade: apesar de têrmos a parte do custo unitário que corresponde às despesas diretas de venda, não nos foi possível obter a parte dêsse custo correspondente às despesas fixas (alugueres, salários, certos impostos, etc.), devido às dificuldades já apontadas. Para contornar essas dificuldades, tomamos as despesas 


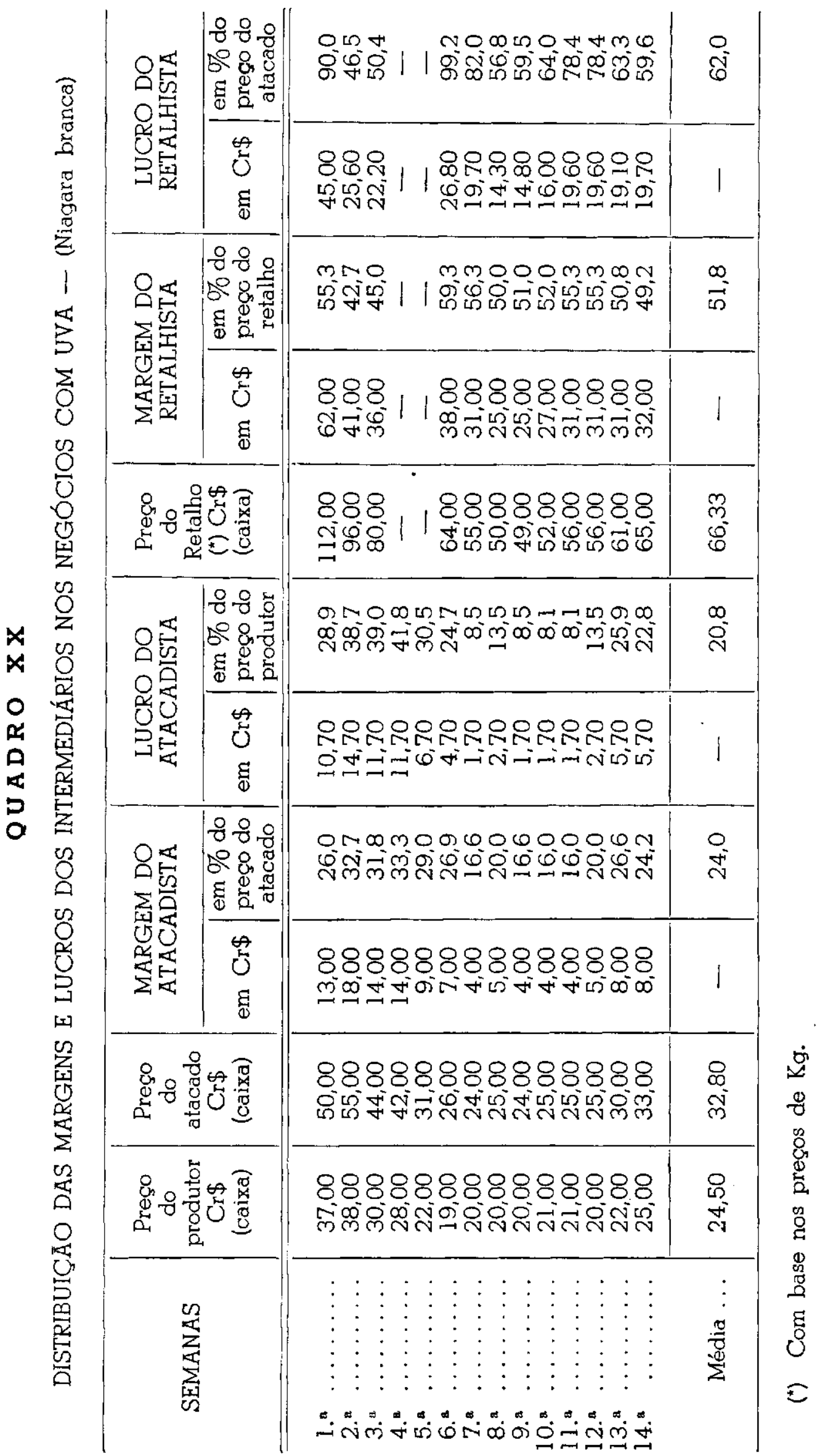




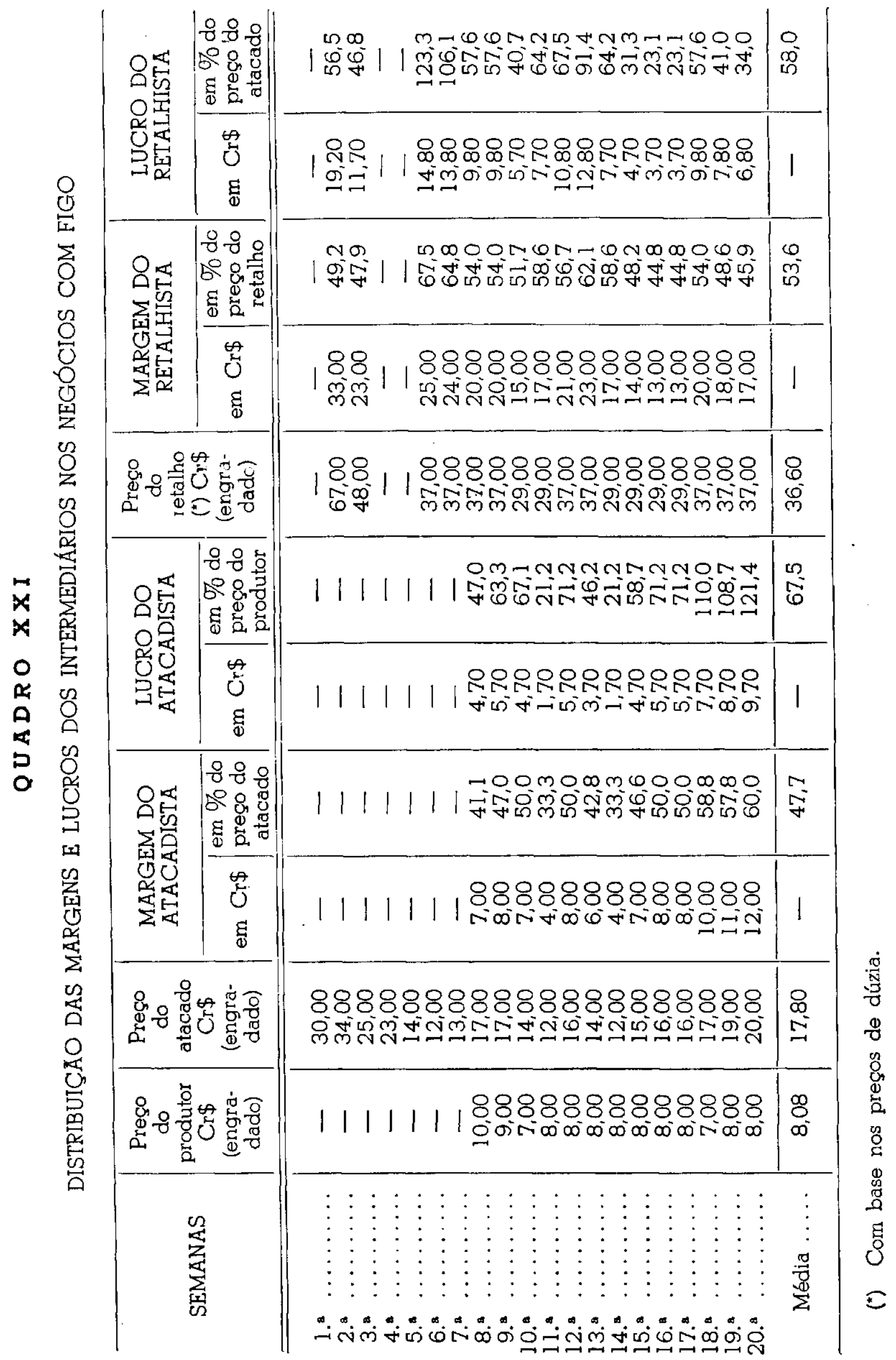


fixas de um atacadista e um retalhista (fruteiro da cidade) típicos (") e, dividindo-as pelos dias do ano, determinamos suas despesas fixas diárias; fizemos, então, recair $80 \%$ (no caso dos atacadistas), e 50\% (no caso dos retalhistas) dessas despesas (**) sôbre o figo e uva vendidos; as quantias que representaram essas percentagens das despesas diárias, divididas pelo volume médio diário de vendas de figo e uva, nos deram as despesas fixas dos atacadistas e retalhistas por volume vendido. Encontramos, assim, as seguintes quantias: atacadistas $=\operatorname{Cr} \$ 0,13$; retalhistas $=\operatorname{Cr} \$ 3,08$.

A estas, juntamos as despesas diretas de venda $\left({ }^{* \star \star}\right)$, obtendo-se as quantias de : $\operatorname{Cr} \$ 2,30$ e $\operatorname{Cr} \$ 5,80$, como correspondendo às despesas totais dos atacadistas e retalhistas, respectivamente, pela venda de um volume (caixa de uva ou engradado de figo). Para a determinação do lucro dos intermediários, descontamos, além dessas despesas, a \% média de perdas, dados êsses fornecidos por nossa pesquisa e de que já tratamos.

Uma vez dadas essas explicações, podemos voltar aos quadros XX e XXI, nos quais os lucros unitários dos intermediários são calculados para os preços médios semanais da safra de 1943/44. O que se nota em 1. lugar é que o lucro dos intermediários é bastante variável, quer em cruzeiros, quer em percentagens, havendo, entretanto, uma tendência para, aos maiores preços, corresponderem os maiores lucros, ou, então, as maiores margens proporcionarem os maiores lucros. Nem sempre, porém, aos maiores preços e margens (em cruzeiros) correspondem os maiores lucros (em percentagem). A cobrança de maiores margens e obtenção de mais elevados lucros de parte dos atacadistas quando os

(*) Ver páginas 490 e respectivamente. Os retalhistas são aqui representados por um fruteiro da cidade, porque os preços do retalho que apresentamos nos quadros XXVII e XXVIII foram coligicos em um estabelecimento dessa classe.

(**) Essas percentagens são as que julgamos mais próximas da realidade, já que não nos foi possível determinar ésses números exatamente. Se o retalhista considerado fôsse um feirante, a percentagem de despesas fixas que recairiam sôbre figo e uva seria bem maior que $50 \%$, pois, conforme dissemos d̀ página 481 , durante a safra de figo e uva, a maioria dos feirantes quase só negocia com essas duas frutas. Além disso, estamos também admitindo que os produtos negociados em outras épocas do ano, alcançam durante êsse período, a importância que figo e uva apresentam nos meses de dezembro a abril.

(**) Para os atacadistas, essas despesas săo as relacionadas a página 470, mas incluindo sómente as que são realmente desembolsadas por êsses negociantes, ou sejam: amortização de vasilhame $=\mathrm{Cr} . \$ 1,21$; frete de retôrno $=$ Cr. $\$ 0,07$; carretos $=\mathrm{Cr}-\$ 0,40$; imposto de vendas $\theta$ consignaçóes $=\mathrm{Cr} . \$ 0,45 ;$ total $=\mathrm{Cr} . \$$ 2,13. (O imposto de vendas $\theta$ consignações, apesar de não constar na relação da pág. 470 foi aqui incluído, com seu valor médio de incidência relativamente aos diversos preços da safra). Para os retalhistas, essas despesas são as relacionadas na página 493, ou sejam : carreto $=\mathrm{Cr} . \$ 1,00$; embalagens $=\mathrm{Cr} . \$ 1,20$; imposto de vendas e consignações $=$ Cr. $\$ 0,50 ;$ total $=$ Cr. $\$ 2,70$ (Também aqui, 0 imposto de vendas e consignaģões foi tomado pelo seu valor médio de incidên. cia, relativamente aos diversos preços da safra). 
preços são mais elevados, já evidencia e poder monopólico dêsses negociantes $e$ indica que os produtores pouco se beneficiam com a elevação de preços, sendo de inferioridade seu poder de barganha com os intermediários, como já mostramos.

A justificativa que os intermediários têm para essa correspondência entre alto preço e maiores lucros é que, geralmente, os preços elevados ocorrem no comêço e fim das safras, quando o volume de vendas é pequeno: os negociantes procuram, então, aumentar a margem e lucro por unidade de venda, para manter em nível normal, seu lucro total. Entretanto, só a possibilidade que êsses intermediários têm, de aumentarem seu lucro unitário quando é pequeno o volume de vendas, já é uma prova do poder monocólico que possuem, pois tal coisa não seria possivel em um regime de competição pura.

Verifica-se, também, que da mesma forma que ocorre com as margens, o lucro dos atacadistas é bem maior nos negócios com figo (média de $67 \%$ ) do que nos com uva (média de $21 \%$ ). Já com os retalhistas, observa-se que é pequena a diferença entre os lucros proporcionados por essas duas frutas $(61 \% \mathrm{com}$ figo e $71 \% \mathrm{com}$ uva). No caso do atacadista, essa diferença de lucro pode ser explicada pela própria desigualdade entre as quantidades de figo e uva ofertadas e negociadas no mercado: a quantidade de figo é apenas 3/5 da de uva; assim, o atacadista cobra maior margem e obtém maior lucro unitário, com a fruta que vende em menor quantidade, a fim de manter em determinado nível o lucro total com êsse ramo de seu negócio. Parece que, por êsse mesmo motivo, o lucro unitário no retalho também deveria ser maior para o figo do que para a uva (ao contrário da quase igualdade que se verifica), uma vez que a quantidade dessas duas frutas ofertadas e negociadas no retalho deve obedecer à mesma proporção que no atacado. Precisamos não nos esquecer, tcdavia, de que, enquanto o atacadista quase só vende essas duas frutas durante essa época do ano, ou, ao menos, que essas são as frutas básicas de seus negócios, o retalhista, ao contrário, lida $\mathrm{ccm}$ muitas outras frutas e produtos durante a safra de figo e uva $\left(^{\star}\right)$; dêsse mcdo o retalhista pcde manter seu lucro total sem aumentar muito - lucro unitário das mercadorias que vende menos, pois muitos outros prcdutcs concorrerão, também, para perfazer êsse lucro total, normal, de negócio.

(") Aliás, para o cálculo da despesa fixa por volume, dos intermediários, já estimamos em 80 e $50 \%$, respectivamente, para os atacadistas e retalhistas, a proporção de negb́cios com figo e uva em relação aos demais produtos verididos durante a epoca da safra dessas duas frutas. 
Como se pode verificar, é bastante elevado o lucro unitário dos intermediários nos negócios com figo e uva, o que fica mais evidenciado pela observação da coluna em que êsses lucros aparecem em percentagem ( ${ }^{*}$ ); aí vemos que êles muitas vêzes alcançam percentagens maiores que 100 , sendo as médias resultantes bastante elevadas. A única exceção, é o lucro dos atacadistas nos negócios com uva, que, assim mesmo, não se situa em níveis baixos. Depois do que expuzemos a respeito do sistema em que se estabelecem os preços nesse comércio, a verificação da existência de altos lucros aos intermediários, não é um fato a se extranhar, pois essa é uma consequência da competição monopolística que prevalece nos mercados atacadista e retalhista. Num regime de competição pura, pela própria fôrça da competição, em pouco tempo a margem de negócio cairia a um nível tal, que daria ùnicamente para pagar um lucro razoável aos negociantes, lucro êsse que não os obrigaria a sair, nem tentaria outros a entrar no negócio. Só sob condições monopolísticas é possível a manutenção de alto lucro por longo período de tempo, como está acontecendo nestes mercados.

Entretanto, o alto lucro unitário, por si só, pouco diz sôbre o lucro total de negócio e é êste que interessa ao negociante obter. Sabemos que existem mercadorias que exigem um alto lucro unitário, para que interessem como negócio, pois, só assim, proporcionariam um lucro total satisfatório. No caso de figo e uva, só nos é possível calcular o lucro global dos negociantes com essas duas frutas, e êste é sòmente uma parte do lucro total de seu negócio. $O$ cálculo dêste último só seria possível à vista da "escrita" dos negociantes, porque figo e uva só são parte importante de seus negócios durante certo período do ano, e nada sabemos acêrca dos produtos negociados nos demais meses; além disso, mesmo durante a safra dessas duas frutas, outros produtos são vendidos conjuntamente (principalmente no retalho) e, também, nada sabemos a respeito do comércio com êsses outros produtos. Dessa forma, só poderíamos afirmar que o lucro total (anual) de negócio dos intermediários é grande se dispuséssemos de dados precisos que mostrassem que êsses outros produtos também proporcionam altos lucros.

Com os dados que possuimos - lucro por unidade de venda e volume de vendas de figo e uva - só podemos afirmar que o lucro dos intermediários na venda dessas duas frutas, durante o tempo que duram suas safras, é grande e paga mais que suficientemente os itens que com-

(*) Percentagens calculadas sôbre o preço de venda dos atacadistas, o qual representa - capital empatado pelo retalhista na transação. 
põem êsse título, isto é, o ordenado do proprietário, os juros do capital e a cobertura de risco do negócio.

Com respeito ao lucro dos intermediários, precisamos fazer ainda uma ressalva : como já vimos, muitas diferenciações feitas nos serviços da comercialização implicam em diferenças no custo de operação de cada um dos intermediários, não só porque os serviços variam com bastante frequência, como por ser variável o volume de negócios de cada um. Devido a isso, o lucro dos intermediários não é uniforme, isto é, nem todos estão obtendo grandes lucros; alguns (atacadistas ou retalhistas) operam com baixo custo unitário e obtêm lucro maior do que aquêles que operam com custo mais elevado.

Devido aos motivos já expostos anteriormente. (desproporção entre oferta e procura e existência de competição monopolística) que possibilitam o estabelecimento de altos preços, mesmo os intermediários com alto custo de operação ainda estão obtendo lucro e não se vêm obrigados a sair do negócio. Se, entretanto, aumentar a produção e diminuirem as possibilidades de diferenciação do produto, os preços tenderão a baizar, e os intermediários que estiverem trabalhando com alto custo terão que estabelecer novas bases de comércio ou sair do negócio; mesmo aquêles que trabalham com menor custo, verão, então, diminuir seus lucros, mas os que forem mais eficientes poderão reajustar suas bases de negócio, diminuindo ainda mais o custo unitário de operação e, assim, manter os atuais lucros.

Finalmente, apesar de a nossa análise sôbre os negócios do retalho se basear apenas em dados de uma frutaria do centro da cidade (*) podemos supor, pelo que já foi dito anteriormente, que as margens e lucros dos feirantes, ambulantes e quitandeiros, são ainda maiores que as dos fruteiros da cidade, pois suas despesas são bem menores que as dêstes últimos e seus preços pouco inferiores aos dos fruteiros.

\section{DISTRIBUIÇÃO DA IMPORTÂNCIA EM CRUZEIROS PAGA PELO CONSUMIDOR PELOS SERVIÇOS DA COMERCIALIZAÇÃO}

Usando os mesmos dados de preços e custos de serviços já apresentados, organizamos o quadro XXII, no qual procuramos distribuir em percentagens, a importância em cruzeiros paga pelo consumidor de figo e uva, pelos diversos serviços da comercialização, tendo, para êsse fim, calculado preços e custos médios da safra de 1943/44. Da mesma forma

(") Isto 6 uma classe de retalhistas de mais alto custo de operação. 


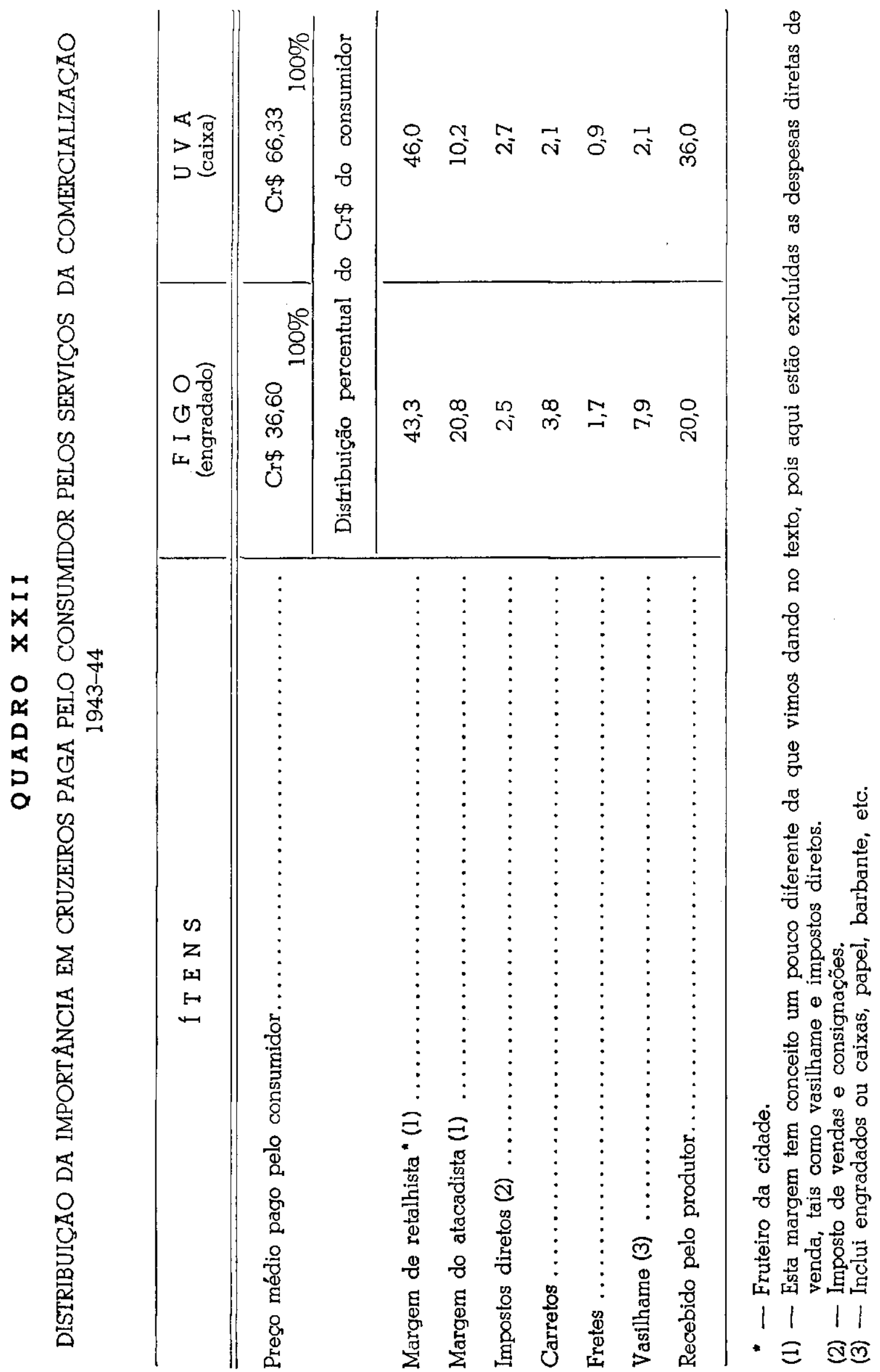


que dissemos para as margens e lucros dos intermediários, os resultados aqui apresentados, têm mais própriamente um caráter de tentativa, dadas as condições particulares dos dados originais.

$O$ que se nota em primeiro lugar nesse quadro, é a diferença entre a parte que cabe ao produtor de figo e a que recebe o produtor de uva : enquanto o $1 .^{\circ}$ só recebe $20 \%$ da quantia paga pelo consumidor, o produtor de uva já recebe uma quantia bem maior, ou seja $36 \%$. Isso se deve à margem do atacadista nos negócios com figo, que é bem maior que a proporcionada pelos negócios com uva, como já mostramos antes e, também, ao mais elevado custo relativo, de certos serviços na comercialização do figo, ou sejam carretos, fretes e vasilhame ; como os preços de figo são bem mais baixos que os de uva, por unidade de volume, e as despesas com carretos e fretes são idênticas para as duas frutas, as despesas com êsses serviços se tornam bem maiores para o figo, quando expressas em percentagens; e a despesa com vasilhame, apesar de ser apenas alguns centavos maior para o figo, torna-se quase 4 vêzes maior que a de uva, quando em percentagem.

Como se pode verificar, do preço pago pelo consumidor, a margem retirada pelo comércio retalhista é a maior de tôdas, chegando a quase $5 \mathrm{C} \%$ dêsse preço. Pelas próprias finalidades e caraterísticas do comércio retalhista, pode-se justificar mesmo que essa parte seja a maior dentre todos os demais serviços da comercialização (*), mas no caso destas duas frutas ela é por demais elevada, tornando-se a maior parcela que concorre para o preço elevado cobrado aos consumidores. Duas causas podem ser apontadas para a cobrança de uma tão alta margem de negócio: a) o alto custo da comercialização a retalho, devido principalmente à ineficiência dêsses negociantes; b) a posição privilegiada dos retalhistas que lhes permite manipular o mercado por longo tempo sem que, pela concorrência, sejam obrigados a se contentar com menores lucros. De tudo que já expusemos antes, pode-se concluir que essas duas causas prevalecem no comércio retalhista. Como no próximo capítulo trataremos da melhoria da comercialização em geral, ali abordaremos êsses pontos com mais vagar e, sob um ponto de vista geral, abrangendo todo o processo da comercialização.

(') O retalho de laranjas da Califómia retira, nos E. E. U. U., 33,3\% do preço pago pelo consumidor. (Clark and Weld, op. cit. pg. 200). 


\section{MELHORIA DA COMERCIALIZAÇÃO}

No estudo que acabamos de fazer sôbre a comercialização de figos e uvas pelos produtores, atacadistas e retalhistas, foram feitas algumas críticas sôbre o modo como êsses produtos são comercializados, porém, no presente capítulo, pretendemos, de um modo mais objetivo, apontá-las, uma a uma, ao mesmo tempo que iremos sugerindo as medidas necessárias para saná-las, visando a melhoria da comercialização dessas frutas:

Pode-se dizer, em resumo, que o comércio de figos e uvas carateriza-se pela existência de exploração e ineficiência. A existência de exploração é comprovada pelo fato de os produtores não obterem uma parte maior do preço de venda, a qual lhes é subtraída pela alta margem cobrada pelos atacadistas e também por serem os consumidores obrigados a pagar pela fruta um preço superior ao que seria suficiente aos retalhistas. Êsses fatos são consequência das condições especiais, já descritas, em que se encontram os mercados atacadista e retalhista. De outro lado, a ineficiência se comprova, principalmente, pelo fato de os intermediários não empregarem plenamente os seus fatôres de produção, como vimos pelos inúmeros exemplos encontrados na descrição da comercialização. Uma das principais responsáveis pela ineficiência do mercado atacadista é a situação de olipólio em que êle se encontra, aliada às restrições que existem para a entrada de novos negociantes, pois estas condições excluem a necessária concorrência que aperfeiçoaria as normas de comércio. Da mesma forma e por motivos que já expuzemos antes, a principal responsável pela ineficiência do mercado retalhista é a situação de competição monopolística aí existente. Além disso, a ineficiência também aparece em setores da comercialização independentes dêstes intermediários, como é o caso dos transportes, da localização do merdado atacadista, etc.

Pode parecer à primeira vista que as falhas da comercialização de figo e uva não apresentam maior gravidade, já que a produção dessas frutas tem aumentado, o que é o sinal de que os lavradores, não obstante a exploração existente, ainda a acham lucrativa e que, o público mesmo com os atuais preços elevados, as vem consumindo em maiores quantidades. Como ainda há muita sobra de terra na zona, é provável que os preços vigentes animem o estabeleimento de novas culturas, isto é, aumente mais a produção, de maneira que, apesar da crescente procura que há, pode não estar muito longe uma situação de excesso de oferta com relação à procura das atuais praças compradoras. Como o alargamento dos mercados para essas frutas é difícil nas precárias condições 
atuais de comércio, êsse excesso de oferta provocará uma grande baixa nos preços e as falhas, principalmente no comércio entre o produtor e o atacadista, se tornarão bem patentes, pois os prejuizos que causarão aos produtores serão bem maiores que atualmente, isso porque os intermediários provàvelmente procurarão diminuir seus próprios prejuịzos, descontando, dos produtores, quantias maiores que as atuais, já que os sistemas de negócio possibilitam êsse abuso.

Por êsses motivos, é necessário que se procure, desde já, melhorar a comercialização dessas frutas, eliminando a exploração e introduzindo maior efictência, a fim de permitir que o mercado se estenda, quer oferecendo frutas a preços acessíveis às classes econômicamente mais desprotegidas, quer levando-as por preços favoráveis a mercados mais distantes sem o que, nos anos de aumento de produção, serão sentidos os efeitos de um abarrotamento de mercado.

Feita esta pequena introdução, iremos agora indicar as principais falhas da comercialização e, ao mesmo tempo, sugerir algumas medidas destinadas a saná-las. Como se verá a seguir, certas medidas se destinam principalmente a diminuir o poder monopólico dos intermediários, isto é, a suprimir o mais possível a exploração existente nesse comércio ; outras visam aumentar a eficiência da comercialização; e outras, enfim, serão efetivas tanto contra a exploração como contra a ineficiência, o que procuraremos evidenciar à medida que as formos indicando. $\left(^{*}\right)$

Padronização e classificação - Já vimos que a única classificação existente para estas frutas, é a feita pelos produtores. Apesar de já representar uma certa melhoria na comercialização, esta classificação apresenta a desvantagem de ser feita sob critérios nem sempre idênticos, diferindo de um para outro produtor, o que impede que os negócios sejam efetuados sob as mesmas bases, favorecendo assim a diferenciação no produto.

Para que haja a desejável uniformidade na classificação, torna-se necessário, primeiramente, o estabelecimento de padrões oficiais para uvas de mesa e figo.

(*) É útil lembrar aqui que muitas sugestões que iremos fazer se aplicam, com pequenas modificações, ao comércio de outras frutas, como a banana e laranja e algumas hortaliças, como o tomate, que, também, já são produzidas em escala comercial entre nbs. Não só serão elas, benéficas ao comércio désses outros produtos, como, provàvelmente, não será econômico aplicá-las ùnicamente a figos $\theta$ uvas; além disso, é preciso considerar-se que a melhoria da comercialização dêsses outros produtos virá contribuir para maior concorrência entre os atacadistas de figos e uvas, obrigando-os a negociar com mais eficiência, como já indicamos anteriormente. 
Além disso, com o estabelecimento dêsses padrões poder-se-ia criar um serviço oficial de classificação, indispensável para a maior segurança dêste comércio. As vantagens que trariam êsses serviços seriam muitas, evitando os abusos comuns nesse comércio. Assim, nos contratos a "preço fixado", o comprador poderia especificar o tipo de fruta que quer receber, e reclamar se a fruta recebida não estivesse de acôrdo com o combinado. De outro lado, o produtor se sentiria mais seguro, pois, classificando sua fruta segundo o padrão oficial, poderia saber o que ela realmente vale quanto à qualidade, e poderia reclamar se o agente faturasse um preço baixo, com a alegação de má qualidade, numa partida classificada e enviada por êle como sendo de primeira qualidade.

O estabelecimento de padrões oficiais parece-nos não apresentar muitas dificuldades de ordem técnica, já que existe bastante experiência com as classificações atualmente feitas.

Quanto à classificação, já se apresentam alguns problemas, pois se fôr oficial e compulsória para tôda fruta, teria que ser feita nos pontos de embarque ou de destino e, em ambos os casos, existe a dificuldade de que a fruta tem que ser colhida, embalada e embarcada no espaço de poucas horas e, uma vez nas estações de destino, tem que chegar logo às bancas dos atacadistas. Dêsse modo, a classificação dessa fruta em qualquer dêsses pontos teria que ser bem rápida, o que exigiria serviço de pessoal numeroso e especializado durante tôda a safra.

Uma classificação facultativa no ponto de destino seria a outra forma em que poderia ser feito êste serviço; o Govêrno manteria, então, classificadores no Mercado de São Paulo, cuja função seria a de proceder à classificação da fruta, sempre que solicitada pelos atacadistas ; isso se daria sempre que êste recebesse, em consignação, fruta "passada" ou estragada, ou se houvesse comprado a "preço fixado" e recebesse fruta de qualidade que não a estipulada. No primeiro caso, seria evitado - prejuizo do produtor que recebe uma fatura depreciada devido a uma alegada baixa qualidade, pois, desde então, êle sòmente concordaria com rebaixa no preço, quando a fatura viesse acompanhada de um laudo de classificação, comprovando o fato; no outro caso, o comprador ganharia com essa medida, pois pagaria só o que a fruta valesse quanto à qualidade, em lugar de pagar o preço anteriormente estipulado. Acreditamos que a última forma de classificação sugerida - a facultativa no ponto de destino - ainda que não represente um serviço completo, é a que apresenta, no momento, maior facilidade de execução, pois exige pessoal menos numeroso e poderá constituir a primeira etapa de um serviço mais completo a ser executado no futuro. 
Caberia ainda ao Govêrno, para efetiva execução dessas medidas, iniciar uma campanha entre os produtores, mostrando as vantagens de classificarem suas frutas de acôrdo com os padrões oficiais e os modos e meios de lançarem mão da classificação oficial, no caso de se verem prejudicados no comércio. Úma campanha com o mesmo fim seria feita junto aos agentes de negócios das principais praças compradoras.

Também no comércio entre atacadistas e retalhistas, esta padronização e classificação se mostraria de tôda conveniência, pois, além de - evitar a diferenciação do produto, sua ausência se traduz aqui em ineficiência, que pode ser medida em têrmos de custo de operação. A classificação possibilitará os retalhistas fazerem suas compras ùnicamente pelo conhecimento do tipo que apresentarem as frutas, tornando-se desnecessária a inspeção atualmente feita pela maioria dos compradores; possibilitará, ainda, que grande parte dos retalhistas façam suas compras por telefone, evitando a perda de tempo em ir ao Mercado. Havendo fruta classificada e generalizando-se o costume de compras pelo telefone, o atacadista poderia se encarregar de fazer a entrega da fruta a todos seus fregueses, o que traria grande economia ao comércio, pois com um só carreto êle serviria um grande número de retalhistas ao mesmo tempo, o que certamente fica mais barato do que cada retalhista fazer seu próprio carreto. Da mesma forma, e não precisamos encarecer aqui êsse ponto, os çonsumidores muito se beneficiariam se tivessem à sua disposição frutas e outros produtos classificados sob padrões oficiais.

Informações de mercado - Uma das maiores falhas no comércio destas frutas e que causa grandes prejuizos aos produtores, é a falta de informações de mercado, das quais a mais importante é a referente aos preços. A criação de um serviço oficial de divulgação de preços, torna-se, pois, uma medida indispensável à defesa dos produtores; entretanto, êsse serviço só será eficiente se os preços divulgados representarem artigo padronizado, sem o que só trarão confusão ao comércio; e, também, se os produtores tiverem a assistência de um serviço oficial de classificação, que os possibilite exigir o pagamento do valor real de sua fruta.

Esse serviço de informações não é difícil de ser executado. Quainto aos preços, poderiam ser fàcilmente obtidos entrando o Govêrno em entendimento com alguns intermediários de honestidade comprovada, que forneceriam diàriamente a uma agência oficial os preços médios dos diversos tipos de fruta durante o dia ; êsses preços seriam enviados diàriamente, pelo telégrafo, aos pontos de embarque e poderiam ser 
afixados nas estações de Estradas de Ferro; dêsse modo, quando fôssem embarcar a fruta, pela manhã, os produtores tomariam conhecimento dos preços que vigoraram em São Paulo no dia anterior, ficando com base para julgarem da justiça com que lhes foi faturada a fruta. Também poderia ser levantada e publicada diàriamente, com dados fornecidos pelas Estradas de Ferro, uma estatística de frutas embarcadas, com destino às diversas praças compradoras; dêsse modo, os intermediários ficariam com elementos para julgarem o movimento de frutas no dia seguinte e sua influência nos preços.

Da mesma forma, um serviço regular de informações sôbre estimativas do volume, qualidade e duração das safras, mudanças nas condições de tempo durante a safra, etc., daria aos negociantes melhor visão das condições do mercado dêsses produtos, diminuiria os riscos da comercialização $e$, consequentemente, tenderia a baixar o custo de operação. Também seriam de grande valor estudos pormenorizados sôbre as condições da procura, suas variações e tendências, etc.

Regularização dos sistemas de negócio - Os sistemas de negócio, à consignação e a "preço fixado", que são usados entre produtores e agentes, apresentam diversas falhas que redundam em prejuizos para ambas as partes.

O sistema à consignação (ou à comissão, como é conhecido entre os produtores), bastante usado e eficiente no comércio em geral, apresenta, no comércio de figos e uvas, alterações prejudiciais e que o afastam do sistema assim denominado no Código Comercial Brasileiro ("). De um modo geral, a principal vantagem que apresenta êste sistema é que a pessoa que consigna pode dispor da mercadoria no momento que achar mais conveniente, isto é, nas melhores condições de preço. Entretanto, o produtor destas frutas não pode usar desta vantagem, pois sendo figos e uvas mercadorias perecíveis, têm que ser vendidas logo que chegam ao mercado, não sendo possível esperar por melhores preços que os vigorantes nesse dia. Por êsse motivo, o negociante dispõe da mercadoria como se fôsse o dono e não um simples consignatário. Aliás, outros fatos já por nós apontados confirmam que, neste comércio, o consigna-

(*) Segundo o Código Comercial Brasileiro, o sistema à consignação é "aquêle em que 0 agente de negb́cio, denominado comissário, recebe uma mercadoria para deposito e posterior venda, por ordem de quem consigna e na data por êste determinada, ou quando êste não determina a data, naquela que o comissário julgar mais vantajosa para o dono da mercadoria".

O mesmo Código estatui que "pelo serviço prestado o agente cobra uma comissão em base anteriormente estipulada com o consignante, ou se não foi estipulada, a que fôr de uso no comércio. 
tário age como se fôsse o dono da fruta, desvirtuando completamente a finalidade do sistema, que é a de proporcionar as melhores condições de vènda ao produtor afastado dos mercados compradores. Assim, por exemplo, a comissão que, segundo o Código, deve ser estipulada entre as duas partes, não o é em geral nos negócios de frutas, nem é a de uso no comércio, pois a cobrada por êstes negociantes varia muito dentro de um critério todo pessoal ; do mesmo modo, o agente envia na fatura ùnicamente o preço líquido, tal como faria um negociante comprador que paga ao preço do dia.

Para que o produtor possa gosar das vantagens do sistema à consignação, seriam necessárias algumas mudanças nas práticas dos atacadistas: êstes deveriam estabelecer prèviamente com os produtores, 0 valor da comissão, deveriam faturar os preços verdadeiramente obtidos pelos diversos lotes de frutas (e não um preço médio, como fazem atualmente) e enviar uma fatura em ordem, detalhando as despesas exatas que tiveram no negócio. Tôdas estas práticas são, aliás, legalmente estabelecidas para os negócios à consignação.

Os negociantes sb adotarão essas práticas se a isso forem levados por meio de medidas indiretas que fortaleçam a posição dos produtores no comércio (ccmo, por exemplo, as já indicadas : padronização, classificação e informações de mercado) e outras, que promovam maior concorrência entre êles e entre as praças compradoras, medidas essas que são indicadas neste capítulo. Além disso, não seria de despresar uma ação educativa junto aos produtores e, principalmente, entre os comerciantes, no sentido de adotarem melhores normas de comércio. Tôdas essas medidas não melhorariam de imediato o sistema, mas sua ação contínua agiria no sentido desejado.

O sistema a "preço fixado" é o que no momento apresenta maior segurança ao produtor; entretanto, para se obter maior segurança seria vantajoso que os negócios fôssem celebrados por intermédio de algum documento legal, onde viriam especificados todos os detalhes de transação, o que evitaria os abusos de que já falamos e de que são vítimas, tanto os prcdutores como os agentes de negócios. Acreditamos que, como uma campanha educativa nesse sentido, uns e outros adotariam essa prática, pois as vantagens para ambos são evidentes.

Existindo serviços de classificação e informações de mercado, acreditamos que se desenvolverão, mais fàcilmente, outros sistemas de negócios que trazem maior segurança ao produtor. Tais são, por exemplo, as vendas f. o. b., venda nos pontos de embarque a representantes dos 
atacadistas, etc. Acreditamos, ainda, que o Govêrno deve estudar e promover a organização de um serviço de leilão no Mercado de São Paulo ou em Pari, não só para estas duas frutas, como também para bananas, laranjas e algumas hortaliças. Este sistema de venda, quando bem organizado e sob a supervisão do Govêrno, com tôdas as facilidades de armazenamento, câmaras frigoríficas e de amadurecimento, é um dos que proporcionam maior segurança e independência aos produtores, concorrendo em elevado grau para diminuir a diferenciação monopolística dos atacadistas, além de promover maior eficiência ao comércio, pois facilitará a compra de fruta aos retalhistas, diminuindo o custo da comercialização.

Transporte ferroviário - Já vimos que a questão do transporte ferroviário é muito importante no comércio destas frutas, devido, principalmente, à própria delicadesa dêsses produtos. Mostramos também que mais de $80 \%$ dos produtores se queixam dêste serviço que tem sido o responsável por muitos prejuizos havidos.

Podemos dizer que as medidas que concorrerão para a melhoria da comercialização só serão eficazes se também houver uma melhoria no sistema de transportes de frutas. Não só a regularidade no transporte, como o cuidado no manuseio de frutas nas baldeações, o emprêgo de vagões apropriados, a observância de horários convenientes a produtores e atacadistas, etc. são pontos que irão concòrrer sobremaneira para a melhoria da comercialização.

A solução das deficiências presentes do transporte de figos e uvas depende, principalmente, de boa vontade por parte de nossas Estradas de Ferro, no sentido de melhorarem os serviços atualmente prestados, o que será possível com a adoção de algumas medidas simples, como sejam :

a) - Que o transporte de tôda a fruta da zona desținada a São Paulo seja feito em apenas um trem de carga que deverá chegar diàriamente ao Pari (S. P. R.) mais ou menos às 20 horas, o que daria tempo para que tôda fruta fôsse descarregada e conferida, e ficasse pronta para ser retirada pelos atacadistas na manhã seguinte, antes da abertura do Mercado (êste abre-se às 6 horas) ; isso evitaria que a fruta vinda em trens de passageiros, como acontece atualmente, pare na estação da Luz e fique por tempo indeterminado à espera de reboque para o Pari, resultando em muitos atrasos; ao mesmo tempo, essa medida simplificaria o carreto de Pari ao Mercado, que se faria uma so vez ao dia e a horas certas : 
b) - As Estradas de Ferro deveriam exigir de parte de seus empregados um maior cuidado no manuseio dos volumes, medida que beneficiaria as próprias Estradas, pelo maior movimento de transportes, pois um dos motivos por que não há maior número de negócios com o interior e outros Estados é o fundado receio que têm os produtores e agentes de que a fruta aí chegue em mau estado, devido às baldeações ;

c) - É indispensável que durante a safra de uva, a E. F. Central do Brasil forneça diàriamente, nas estações de embarque, os vagões necessários para os despachos diretos para o Rio de Janeiro, o que diminuirá o custo de operação para os produtores e tornará seguro o abastecimento daquela praça com fruta de boa qualidade.

Além dessas medidas, que deveriam ser tomadas desde já, as nossas Estradas deveriam estudar outras, com o fim de serem proporcionadas, no futuro, condições de transporte propícias a um alargamento dos mercados de figos e uvas de mesa e que as colocasse em posição vantajosa frente ao transporte rodoviário que tenderá a se desenvolver bastante (*) uma vez superados os impedimentos provenientes da guerra; entre algumas dessas medidas, poderemos citar : fornecimento de vagões mais apropriados para o transporte de frutas frescas, e fretes mais baratos para os mercados mais distantes das zonas produtoras. $\left({ }^{*}\right)$

Localização do mercado atacadista - Outra falha do comércio, que devemos focalizar, é o da impropriedade da localização do mercado atacadista de frutas, no Mercado Municipal de São Paulo. Este Mercado abriga não só êstes negociantes, como também atacadistas e retalhistas de outras frutas, de hortaliças, de ovos, aves, lacticínios, conservas, gêneros alimentícios, em geral, açougues, produtos de cerâmicas, etc., além de um matadouro avícola. Entre outras desvantagens desta localização, queremos sòmente salientar a que resulta da mistura de comércio atacadista e retalhista em um mesmo recinto. É sabido que cada um

(") Há um fato interessante a citar, com relação a êste assunto : no ano de 1944, devido à queda de barreiras em um dos tíneis da serra, na E. F. C. B., o tráfego ferroviário entre S. Paulo e Rio esteve paralizado durante mais ou menos um mês; um atacadista de São Paulo conseguiu, então, enviar, durante muitos dias, a média de 100 engradados de figo para o Rio por intermédio de uma linha regular de aviōes, pagando $\operatorname{Cr} \$ 13,00$ de frete por engradado, o que ainda foi compensador, dado o preço que então alcançou a fruta naquela praça : Esse fato $e$ bastante significativo do que poderá acontecer regularmente em um futuro próximo.

("*) O contrário desta última medida $㇒$ o que se tem dado: no início do ano de 1944 houve um aumento de tarifas que muito prejudicou êste comércio, chegando a haver casos, como o dos despachos para o Rio de Janeiro, em que as despesas da comer. cialização dobraram com relação ds do ano anterior, principalmente devido ao aumento das tarifas. 
dêstes comércios tem diferentes finalidades, volume de negócios, etc. e, portanto, diferentes necessidades. $O$ Mercado foi construído para servir ao comércio retalhista de frutas e hortaliças, de modo que suas acomodações e divisões são apropriadas a êsse fim. Entretanto, para o comércio atacadista, que pouco a pouco se foi estabelecendo no recinto, essas acomodações são absolutamente impróprias, resultando num encarecimento de serviços. Podemos apontar diversos fatos que apoiam nossa afirmativa. Em primeiro lugar, a exiguidade das bancas dos atacadistas, as quais não comportam um armazenamento razoável, não só de frutas, como também de vasilhame vasio que o atacadista tem em depósito; essa exiguidade, o obriga a arrendar mais de uma banca para seu negócio (o que diminui a possibilidade de entrada de novos atacadistas) ou alugar espaço fora do Mercado (o que encarece os serviços). Em segundo lugar, temos a notar a falta de desvios ferroviários até o Mercado, o que é de grande importância em um mercado atacadista : a economia de tempo e dinheiro que traria a êsse comércio a conexão ferroviária, seria bastante compensadora, pois evitaria não só os inúmeros carretos atualmente pagos, como também as baldeações que tão maus efeitos causam a produtos delicados como são as frutas. $O$ terceiro ponto a notar é a falta de facilidades para os caminhões e carrinhos chegarem até as bancas, o que obriga ao pagamento de novos carretos e maiores manipulações com o vasilhame. Mesmo para os descarregamentos nas portas do Mercado, não há facilidade, pois a maioria dessas entradas dão para uma rua estreita, de grande movimento e com duas vias de bondes, o que torna enorme a balbúrdia ali existente durante a maior parte do dia. Outra desvantagem é a dificuldade de acesso ao Mercado, que é servido ùnicamente por uma via de bondes e outra de ônibus e que, sendo as únicas conduções que servem dois bairros populosos, passam pelo Mercado em seu trajeto.

Finalmente, o principal inconveniente da atual localização dos atacadistas no Mercado Municipal de São Paulo, é ser êste um recinto fechado e já estarem arrendadas tôdas as bancas. Dêsse modo, o ingresso de novos comerciantes no atacado de frutas se torna bastante difícil e só possível mediante altas compensações pagas aos atuais arrendatários; cria-se, dessa forma, um privilégio de todo inconveniente, que é o principal responsável pela pequena competição existente entre os atacadistas e que tem possibilitado a manutenção de altos preços para essas frutas e grandes margens para os atacadistas.

É pensando no grande volume de frutas e hortaliças concentradas diàriamente na cidade de São Paulo, para posterior distribuição, e nas 
vantagens de centralização dêsse comércio em local apropriado, que achamos de grande necessidade estudos detalhados sôbre outra localização para êste comércio, com construções simples e despretenciosas, mas que correspondam perfeitamente às suas reais necessidades, com desvios ferroviários próprios e outras facilidades para o transporte e descarregamento das frutas, recinto apropriado para leilões, etc. E é claro que essa iniciativa não pode ser deixada a cargo de particulares, cabendo ao Govêrno prover essa necessidade.

Armazenamento - Por diversas vêzes, neste trabalho, já dissemos que não é costume entre os atacadistas armazenar estas frutas por mais de 2 ou 3 dias em suas bancas, pois elas se deterioram com muita facilidade $\left(^{*}\right)$. Êste fato pode tornar-se o fator de flutuações fortes de preços por causar congestionamento ou fallta de frutas no mercado. Desde que o produto, uma vez maduro, não pode ficar retido nos centros de produção, o armazenamento no mercado atacadista possibilitaria regular a quantidade posta à venda e agiria, até certo ponto, como regularizador dos preços.

Apesar de o Mercado Municipal estar provido de câmaras frigoríficas relativamente espaçosas e ser razoável a taxa cobrada $\left({ }^{* *}\right)$, elas nunca foram usadas pelos atacadistas de figos e uvas. Um dos motivos dessa abstenção parece ser a ignorância dos atacadistas sôbre o efeito dêsse armazenamento sôbre a qualidade da fruta. Apesar de parecer problemático êsse resultado com relação às atuais variedades de uva, é necessário que o Govêrno promova estudos referentes ao efeito do frio industrial sôbre essas frutas, à semelhança do que já foi feito em outros paises, sob outras condições ecológicas. É importante que tais estudos sejam acompanhados de dados econômicos, sem os quais não seriam de utilidade para o comércio. Da mesma importância seriam os estudos que se fizessem sôbre câmaras de amadurecimento para estas e outras frutas e também hortaliças.

Vasilhame - Um dos pontos fracos da comercialização é que o vasilhame usado na embalagem destas frutas está, atualmente, muito caro e ccmo a despesa com seu fornecimento na maior parte dos casos vem recair sôbre os prcdutores, êstes vêem bem diminuída sua margem

(") Esta pequena resistência à deterioração é um fator de muita importância que limita a eficiência da comercialização. A necessidade de produção de uvas com maior grau de resistência, quer melhorando as atuais variedades, quer introduzindo novas, apesar de ser um ponto fora do tema dêste estudo, não pode ficar sem menção, tal é a sua importância.

(*) Cr $\$ 1,00$ por mês e por volume. 
do lucro. Além disso, os despachos e redespachos que sofre, concorrem para o encarecimento da comercialização, além de ser causa de muita controvérsia e exploração, tanto da parte dos atacadistas e retalhistas, como da parte dos produtores.

Seria de grande utilidade, pois, que o Govêrno fisesse estudar, pelos Instituto de Pesquisas Tecnológicas e Instituto Agronômico um tipo de vasilhame, ou, ao menos, um tipo de gaveta para figos, feita com material mais barato e que pudesse ser dado ao consumidor sem grandes despesas para os produtores ou atacadistas.

Impostos - Muito pouco podemos dizer sôbre o grau de importância que, na comercialização, têm os impostos cobrados aos intermediários pelas repartições federais, estaduais e municipais. Como os intermediários negociam com diversos artigos e não nos foi possível examinar seus livros comerciais, não pudemos calcular qual a parte de impostos que recai sôbre uva e figos, e dizer se é excessiva ou não. Acreditamos, todavia, que à parte o caso do imposto de vendas e consignações, que é taxado duplamente, o montante dos impostos pagos pelos atacadistas não é desarrazoado; no caso do retalho, entretanto, acreditamos ser necessária uma revisão em seus impostos, não só porque o total é elevado para certas classes de retalhistas, como as formas e épocás de cobrança são muito variáveis, o que quase sempre causa aborrecimentos e perda de tempo às partes interessadàs. Aliás, como já assinalamos, foram abolidos, em 1944, os impostos estaduais e municipais que pesavam sôbre a classe dos ambulantes e essa medida, sem dúvida alguma, teve um efeito benéfico na comercialização de frutas; é, porém, de justiça e de vantagem que as demais classes de retalhistas também sejam beneficiadas com medida semelhante ou, ao menos, que suas tabelas de imposto sofram uma revisão, de modo a tornar mais atraente êste negócio.

Serviços inadequados aos consumidores - Sob êste título queremos apontar aqui uma das principais falhas do comércio retalhista de frutas, responsável pela sua ineficiência e pelo pequeno consumo por parte da população. É bem verdade que não póderemos apontar, como até aqui temos feito, algumas medidas tendentes a saná-las, pois elas só se modificarão pouco a pouco, pela ação da educação e das mudanças em outros fatôres, como sejam o volume de negócios, poder aquisitivo da população, etc. Entretanto, como essas falhas caraterizam bem o atual comércio a retalho, não devèmos deixar de apontálas. 
É sabido que uma das funções do comércio retalhista é criar uma procura para as mercadorias disponíveis no mercado, para o que necessita estar devidamente aparelhado a fim de prestar os serviços exigidos pelos consumidores.

Neste comércio, entretanto, êsses serviços ainda deixam muito a desejar, o que é sinal de que os retalhistas ainda não se capacitaram da importância daquela função. Assim é que os estabelecimentos retalhistas de frutas, geralmente se encontram em locais destituídos de higiene e acanhados, e isto não só causa transtôrno aos compradores e vendedores, como não é de molde a atrair freguesia; nem sempre as frutas estão dispostas de um modo atraente e que desperte a atencão dos compradores, ou devidamente separadas em tipos, de modo a facilitar a escolha dos consumidores; de outro lado, nem sempre o tratamento dispensado aos fregueses é atencioso e polido, isto é, não é o que se esperaria de quem deseja ver progredir seu negócio.

Tôdas essas falhas são indicativas do pequeno esfôrço que fazem os retalhistas para aumentar a procura de frutas por parte da população, o que concorre, no final, para o pequeno volume de vendas dos retalhistas e a necessidade de cobrar uma alta margem por unidade vendida.

Desperdício - Esta é outra falha dêste comércio, indicativa da ineficiência em que êle funciona e para a qual também não podemos indicar nenhuma medida que atue em caráter imediato para saná-la. O desperdício é particularmente visível no comércio retalhista e só quando, por mudanças em outros setores de comercialização, êste comércio se tornar mais eficiente e de caráter menos monopólico, o desperdício irá desaparecendo. Alguns poucos exemplos, tomados por nossa observação pessoal, mostrarão o desperdício que existe atualmente. Assim, é comum observarmos que, ao término das feiras, muitos feirantes estão "encalhados" com 2 ou 3 volumes de frutas que, em geral, êles distribuem ali mesmo, entre a garotada, ou reservam para o consumo da própria família; sem discutir o mérito dessa aplicação, acreditamos que êsse fato representa, indiscutivelmente, um desperdício, cujo resultado final é o encarecimento da fruta, pois isso só é possível por ser muito elevada a margem cobrada nos demais volumes vendidos; assim, também, o ambulante, pelo mau trato a que sujeita a fruta (uso de carrocinhas sem molas em nossas ruas mal calçadas), não só a apresenta em piores condições que outros retalhistas, como também deve ter uma maior percentagem de perdas, o que redunda em encarecimento da fruta ; outra modalidade de desperdício que se observa, é a ausência 
de qualquer aparelhamento dos retalhistas (principalmente os de frutarias) destinado à melhor conservação das frutas; a mercadoria fica, em geral, exposta à poeira e insolação e sujeita às bruscas mudanças de temperatura, muito comuns entre nós; durante a noite permanecem em ambiente abafado e cheio de moscas, etc. ; tôdas essas são condições favoráveis a uma rápida deterioração, aumentando o risco do negócio e, consequentemente, o custo da comercialização.

A execução do conjunto de medidas, aqui propostas, ainda que não resulte numa comercialização perfeita de figos e uvas, deve ser o passo inicial a ser dado, visando a sua melhoria. Elas não só serão úteis aos produtores, como ainda aos intermediários e consumidores. Aos produtores, serão benéficas por lhes trazer maior segurança $e$ independência na parte mais difícil de suas atividades, ou seja na venda do produto; como consequência, êles se animarão a produzir de um modo mais eficiente e em maior quantidade. Aos intermediários e consumidores, também beneficiarão, não só por lhes trazer também maior segurança em seus negócios como por obrigar os intermediários a negociar com mais eficiência, o que redundará em benefício para ambos. Além disso, pelo amparo que essas medidas darão à produção e ao comércio de figo e uva, será incentivado espontâneamente, entre nós, o estabelecimento de produção comercial de outras frutas e hortaliças, objetivo altamente desejável sob todos os pontos de vista.

Todavia, considerando que o comércio e o consumo de figos e uvas estão ligados ao de frutas em geral, é preciso acentuar que para êle atingir um maior grau de perfeição se faz necessário que ocorram algumas mudanças em certas condições gerais da produção e consumo dessas frutas, condições essas que, em grande parte, são as responsáveis indiretas pela ineficiência da comercialização de figo e uva. Ainda que uma mudança nessas condições só se opere lentamente, com o correr do tempo, não podemos deixar de mencioná-las aqui, tal a sua importância na melhoria da comercialização de figos e uvas e de frutas em geral.

A primeira dessas condições que precisamos mencionar é o pequeno número de frutas produzidas comercialmente entre nós. Já dissemos que, com exceção de banana e laranja e, em menor grau, de figo, uva e abacaxi, as demais frutas de consumo do nosso povo se apresentam com uma produção pequena, esporádica, esparsa por todo o 
Estado, sendo cultivadas mais com o fito de abastecer os próprios centros de produção e não os grandes centros consumidores; enfim, apresentam uma produção de tipo auto-suficiente.

A comercialização de artigos em geral com êste último tipo de produção, é, naturalmente, cara, sujeita à exploração e ineficiente. Assim é que se tornam anti-econômicas certas aparelhagens e facilidades de comércio como o transporte rápido e seguro, armazenagem adequada, agentes de compra nos centros de produção, padronização e classificação, etc. Da mesma forma, êste tipo de produção possibilita que os negociantes adotem normas pouco corretas de negócio e tenham certa "folga" nas despesas, pois os produtores não estranham $\circ$ pouco que recebem por seu produto, já que êste representa apenas um "biscate" para êles. Finalmente, talvez a pior consequência trazida por êste tipo de produção ainda vigorante entre nós seja o fato de que, não proporcionando um variado e grande sortimento de frutas, os intermediários se vejam obrigados a manter uma escala de operação muito pequena, impossibilitados de usar com plena eficiência os seus fatôres de produção e, portanto, obrigados a cobrar uma elevada margem unitária de negócio.

Outra condição geral que concorre para a ineficiência dêsse comércio diz respeito à falha educação comercial do nosso consumidor. De um modo geral, o nosso povo não sabé comprar, isto é, não utiliza com eficiência os meios de que dispõe para adquirir o que necessita. Preliminarmente, não sabe escolher, conforme a época, o que convém comprar, pois existem períodos do ano em que os preços são altos (épocas de escassez) e outros em que os preços são baixos (épocas de abundância); a escolha dos produtos que deve comprar, segundo os níveis de preços no momento, é prática ainda pouco usada pela maioria de nosso povo e, sem dúvida alguma; é de grande importância na economia doméstica de cada família. É igualmente pequeno o conhecimento de nosso povo de como e onde comprar ; não é muito de seus hábitos fazer especulações sôbre preços de artigos de alimentação entre as diversas casas do ramo, em balancear as vantagens ou desvantagens dos diversos serviços prestados pelos negociantes; do mesmo modo, não é comum - conhecimento e a exigência do público consumidor com relação à observância das diversas variedades, tipos e qualidades dos produtos, exatidão no pêso ou número de unidades, etc., o que diminui em elevado grau a capacidade de barganha do consumidor e não é de molde a animar os negociantes a adotarem melhores normas de comércio. 
De outro lado, é recente, entre nós, o conhecimento das vantagens do emprêgo de frutas no regime alimentar, motivo por que essa prática é relativamente reduzida em nosso meio. Na realidade, as campanhas, que nesse sentido até agora têm sido feitas, precisariam ser ampliadas, e apresentar cunho mais objetivo, para um melhor conhecimento e prática, principalmente entre as camadas médias e mais pobres da população, pois, com pequenas exceções; as frutas são ainda consideradas entre nós como "sobremesa", não fazendo parte da alimentação diária da maioria do povo. Êsse baixo consumo também concorre para limitar o volume de negócios dos comerciantes, obrigando-os a negociar em pequena escala e, portanto, a cobrar uma margem mais alta por unidade vendida.

Dêsse modo, é necessário que, por meio de uma melhor educação comercial e dietética, os consumidores passem a comprar mais eficientemente, utilizando seu dinheiro de modo mais econômico; assim fazendo, o comércio irá sendo obrigado a modificar suas normas de trabalho, tornando-as mais justas e, ao mesmo tempo, mais eficientes, entre outros motivos, porque lhe proporcionará maior volume de nexócios.

Finalmente, outra condição encontrada entre nós, e que é um fator limitante para a maior eficiência do comércio de frutas, é o fraco poder aquisitivo do nosso povo. A situação de baixo consumo daí resultante é, como já indicamos, uma das causas do pequeno volume de negócios do comércio de frutas, que assim se vê desencorajado e, em certos casos mesmo, impedido de melhorar seus métodos de negócio, tornando-os mais eficientes e econômicos.

É necessário acentuar, pois, que a maior eficiência na comercialização de trutas só se verificará se também houver um aumento no poder aquisitivo de grande massa de nossa população, que ainda não consome grandes quantidades dêsses produtos, em virtude da falta de meios para adquirílos, mais do que por qualquer outro motivo.

\section{SUMMARY}

In this publication the marketing of figs and grapes that are produced in the region situated among the cities of Campinas, Itatiba and Jundial are studied. The principal characteristics of this region are described.

Data and information on the services carried out by growers and middlemen were obtained personally by the author by the survey method. Other methods were used to otain prices and shippina data. The marketing activities of growers, wholesalers and retailers were studied separately.

The services performed by the growers are packing, classification, transportation to railway stations and freight payment to the market. Each of these services are described 
with statistics data and fully criticized. It is shown that no official standards exist for these fruits and consequently, the farmers grade their production according to their own criterion. The only means of transportation between producing centers and markets is the railway. Growers and dealers have justified complaints against the railway companies services. They claim that the time is too long, the freight cars are unfit for perishable products, there muchihe carelessness in the manipulation of packs, there is no direct transportation to Rio de Janeiro and the freight rates are too high.

It was found that almost ninety percent of the growers sell their production through the wholesalers located in the Municipal Markets of São Paulo and Rio de Janeiro cities, the remaining ten percent being sold directly to retailers and consumers.

The growers use two methods of sale, the first on consignment, wherein the wholesaler receives and sells the fruit at the day price, deducts his commission and selling expenses and sends bach to the grower the rest of the gross returns. The second method, "fixed price", enables the grower to sell to a wholesaler all or part of his production at a fixed price per unit, usually fixed before the season. The advantages and disadvantages of these two methods of sale are discussed. Of the interviewed growers, 62.4 percent sell on consignment but only 12.7 percent of these growers receive a bill which shows the amount of the gross returns and a detailed account of selling expenses.

More than two-thirds of the production of the region goes to São Paulo city, the rest being sent to Rio de Janeiro, Santos and other cities in the State. (see table).

Data on the growers marketing expenses are given. The most outstanding items are packing paper, freight, packing case amortisation, sale and consignment tax and the agent's commission. The ways by which the consignees calculate their commission which sometimes reaches as high as fifty percent of the selling price, are described.

The wholesale and retail markets of both products are described and details are given on the selling methods, dealer's locations, buyers' classes, selling hours, selling units, quantities sold and risk. In the description of the retail markets, each class of retailers is dealt with separately, such as, fairs, groceries, hucksters, green groceries, hotels and restaurants.

Based on information and data obtained from a few typical dealers, the marketing expenses of wholesalers and retailers are listed. The items included are fixed expenses such as rent, wages and taxes and direct selling expenses such as packing and transportation.

A study on prices of figs and grapes shows that the prices are to high for the most part of the population and that the growers are not duly compensated with any raise in consumer prices. To elucidate the causes of these facts, a study was made of the fig and grape supply and demand factors and the system by which prices are set. An analysis shows that the following factors affect the annual prices: annual production, season length, population purchasing power, consumption habits, competition of similar fruits and variations on the internal purchasing power of the money. As to daily price variation the following factors of supply and demand were analyzed: daily shipments to São Paulo, stocks, festive days and weather conditions. This analysis shows that the raise in last years' prices was due to the increase in demand. Demand has greatly increased by the joint action of a raised purchasing power of some consumer classes and increased fruit consumption habits. The growers have been unable to supply the quantity demanded. The fall in the internal purchasing power of the money must have also contributed in raising the prices. 
Studying the system by which the wholesale and retail prices are set, it was found that these markets are operated on a monopolistic competition basis, as termed by $\mathrm{E}$. W. Chamberlin. In the wholesale market this situation is made possible on account of the small number of dealers in trade and the differentiation of "product," (there is evidence of an oligopoly plus differentiation). Differentiation is found both in selling and buying operations. In the retailer market the monopolistic competition is due to the great differentiation in "product" which is favored by several factors that are ennumerated. The consequences of these conditions are pointed out: the prices are set in a very high level, the dealers' margins are greater and the operation seale is smaller than it could be if these markets were operated under pure competition. The possibilities of increasing the number of wholesalers and of lessening the differentiation of the product are discussed.

The margins and profits of the middlemen int the marketing of figs and grapes are calculated as a first step. Using the same data, it was made an lattempt to distribute the consumer "Cruzeiro" by the services of commercialization.

Lastly, several measures to better the commercialization are suggested, some of them with the purpose of lessening the middlemen monopolyc power thus increasing the bargain power of the growers and consumers, and some others with the purpose of giving more efficiency to the commercialization. The following measures are discussed: standardization and grading services, market news, regularization and use of new methods of sale, better and cheaper transportation services, better localization of the wholesale market, studies on storage, studies on the use of cheaper package, tax system revision, measures against waste, and better service to the consumers.

Further discussed is the fact that the cause of weakness of the trade of figs and grapes in São Paulo, as in the case of all fruits in general, is to be found, primarily, in the lack of commercial education of the population, in the weak purchasing power of the greater part of the population and in the small amount of fruits commercially produced. 


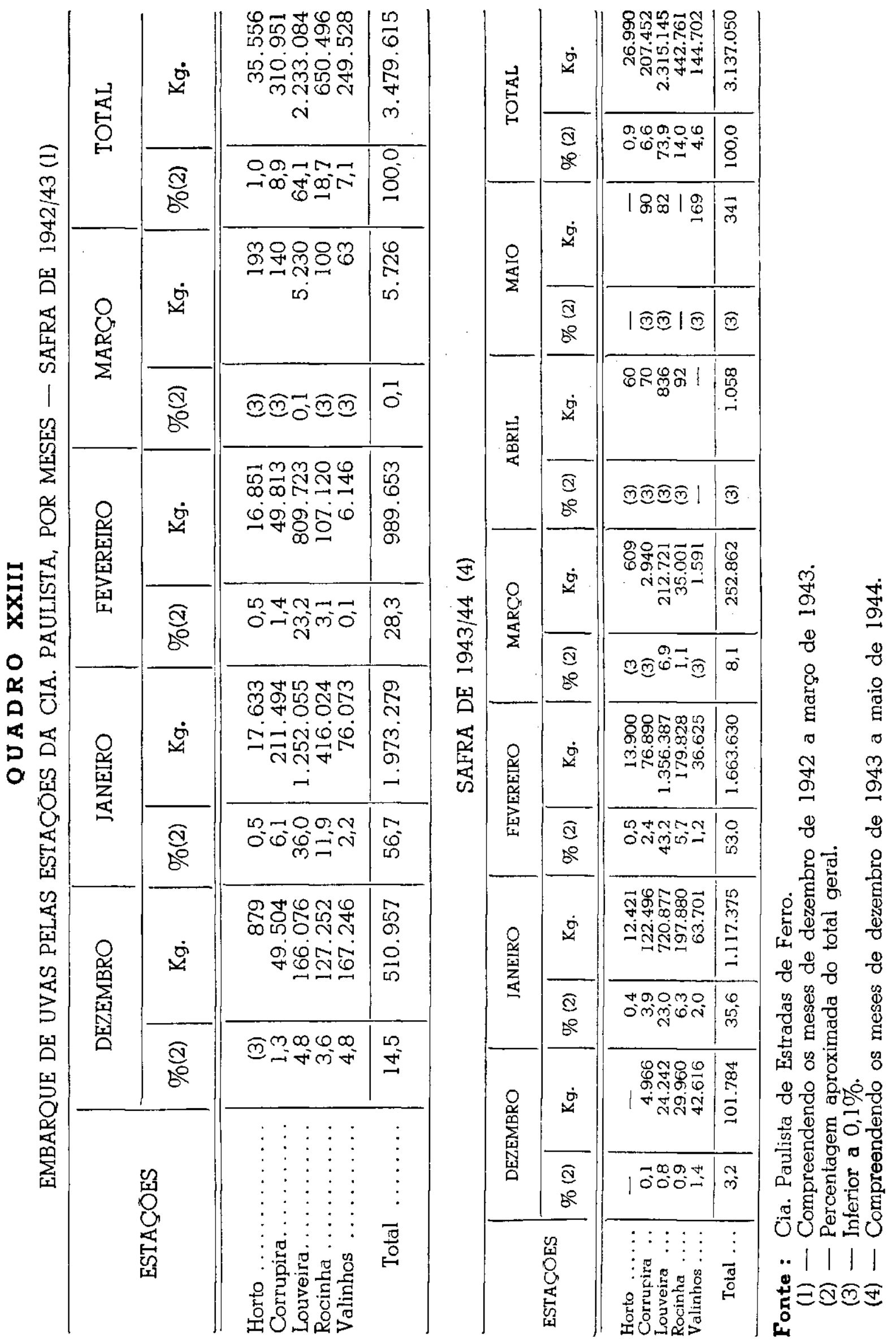




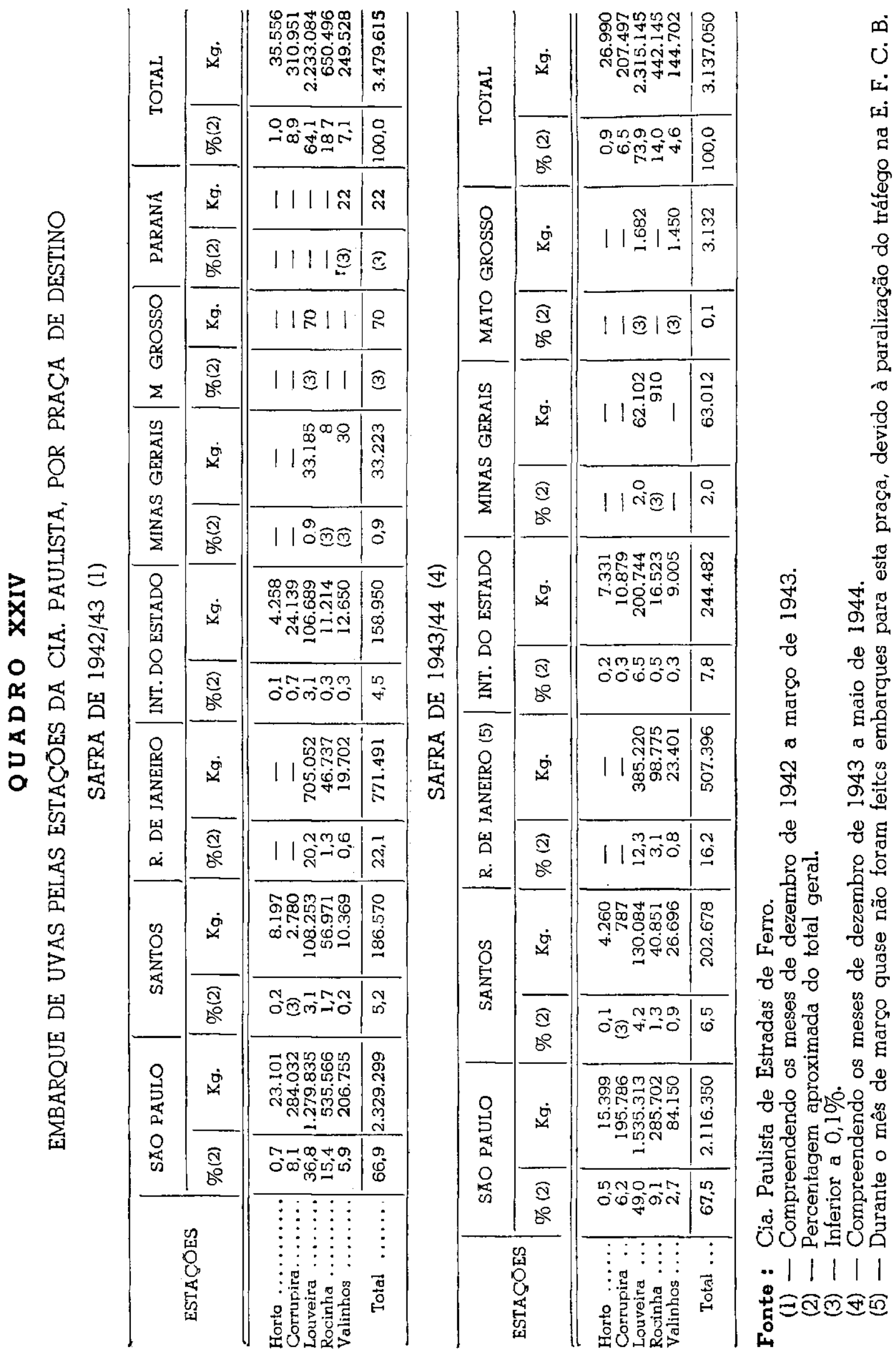




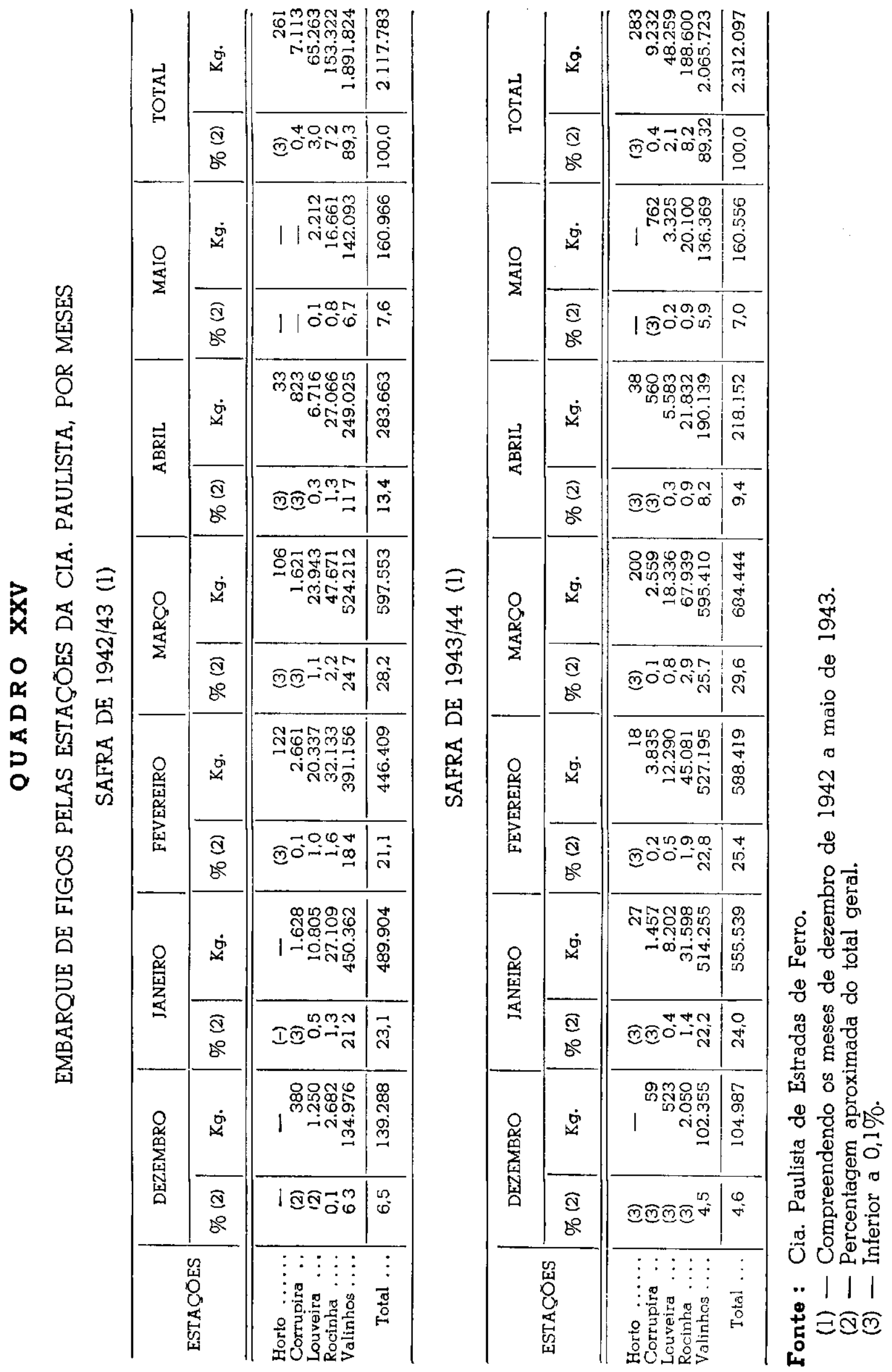




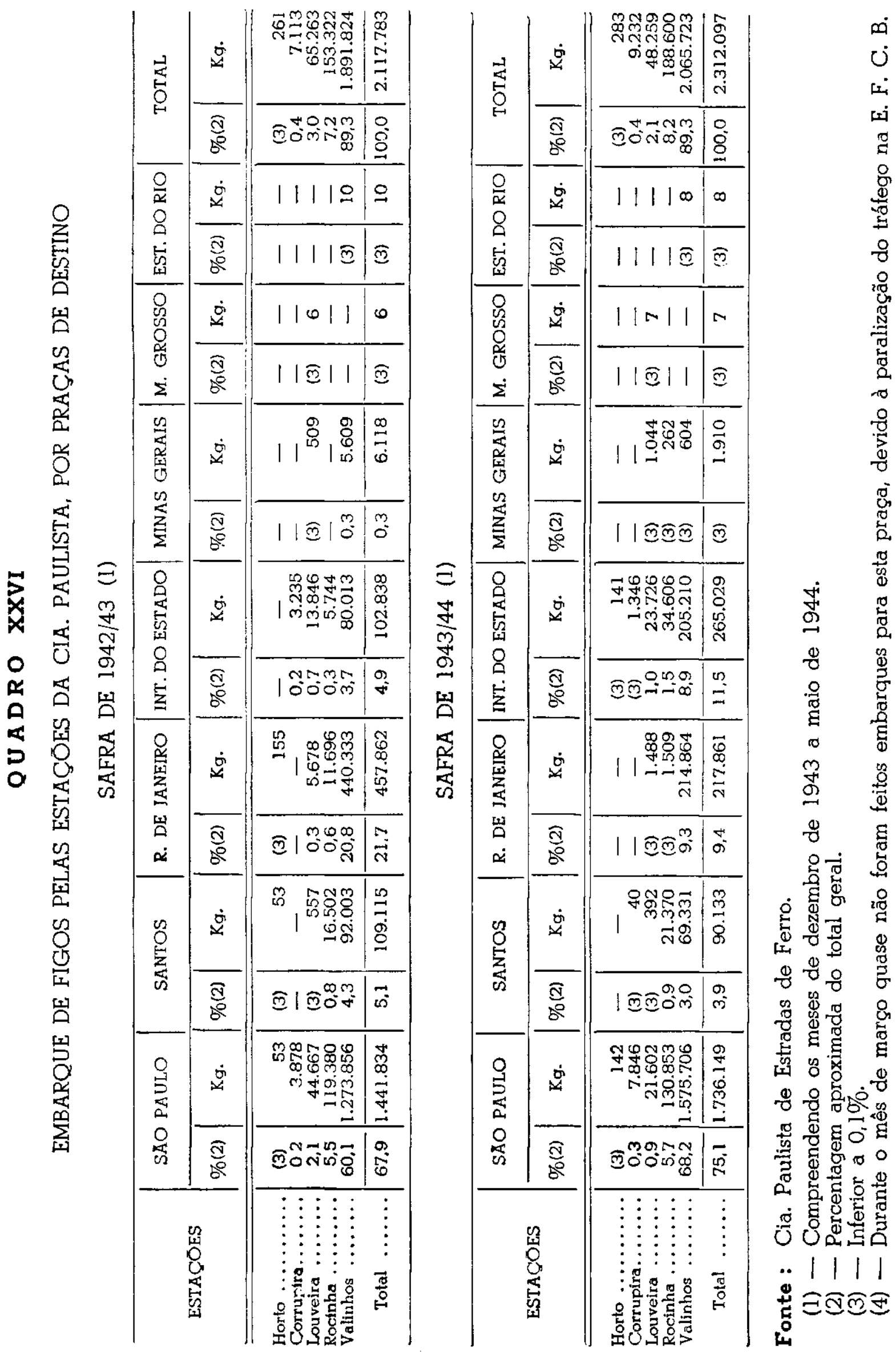


$\begin{array}{llllllllll}\text { PRECS DE UVA } & \text { NA } & \text { SAFRA } & \text { DE } & 1943 / 44\end{array}$

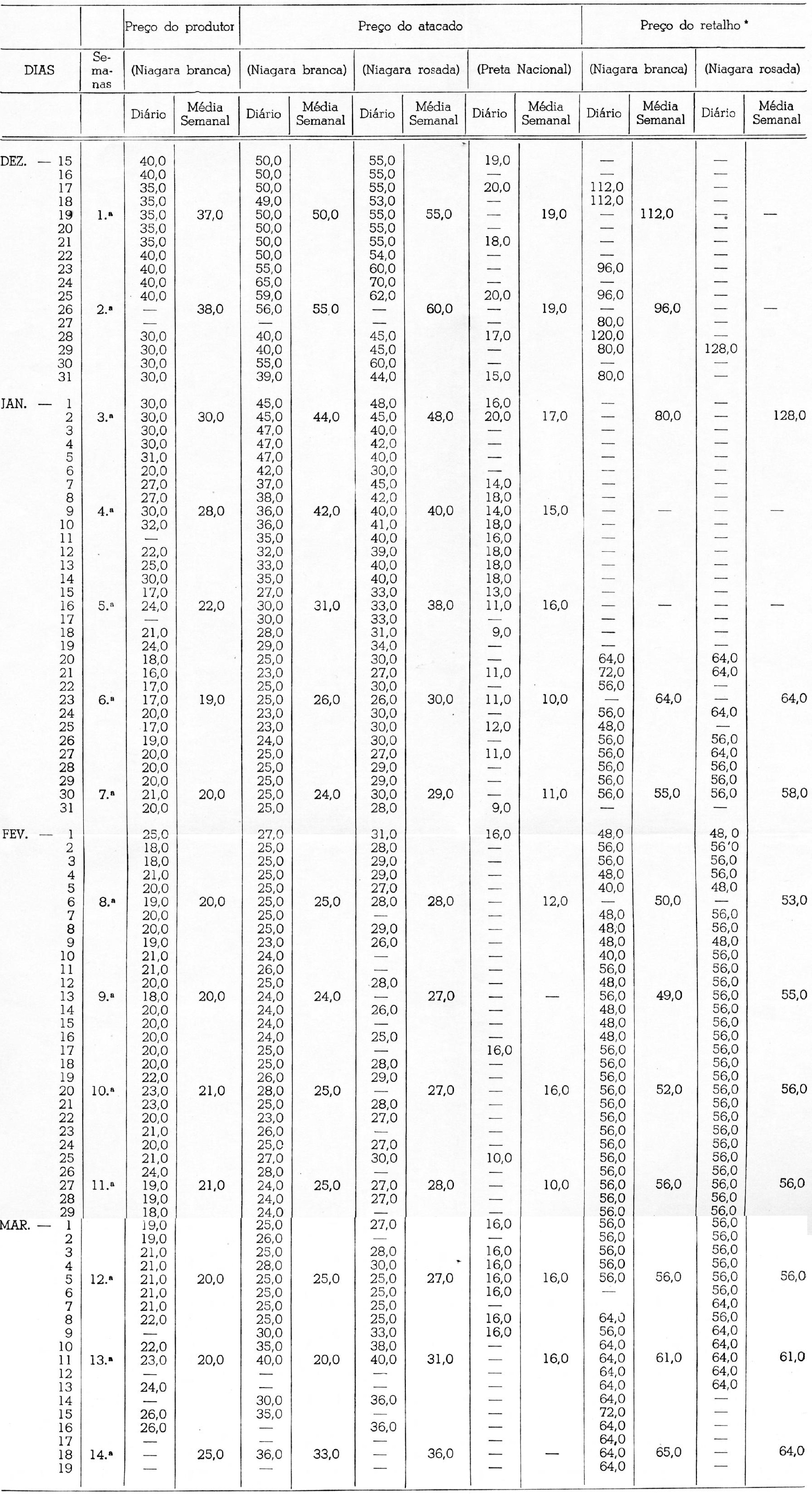


QUADRO XXVIII

PREÇOS DE FIGO NA SAFRA DE $1943 / 44$

TIPO 1-A - (Engradado)

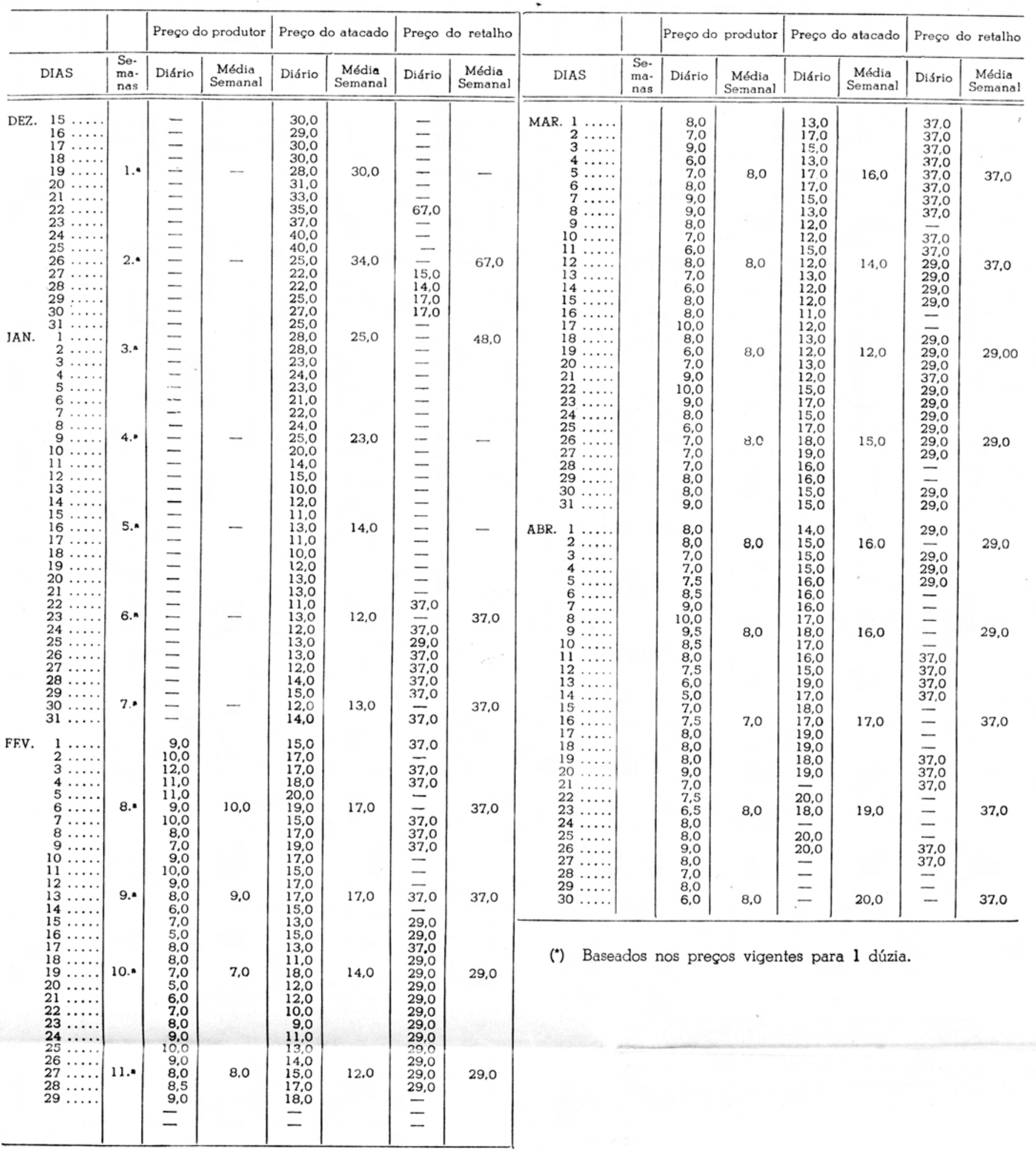

